\title{
PRE-TITLE I SAFETY EVALUATION FOR THE RETRIEVAL OPERATIONS OF TRANSURANIC WASTE DRUMS IN THE SOLID WASTE DISPOSAL FACILITY (U)
}

August 1994

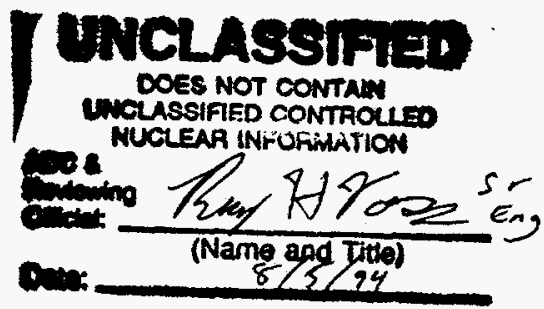

Westinghouse Savannah River Company

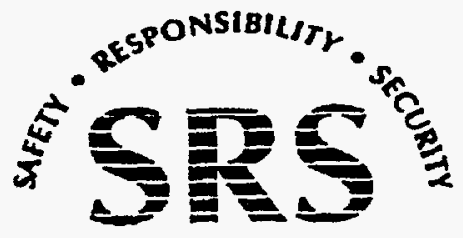

SAVANNAH RIVER SITE

PREPARED FOR THE U.S. DEPARTMENT OF ENERGY UNDER CONTRACT NO. DE-AC09-89SR18035 


\section{DISCLAIMER}

This report was prepared by Westinghouse Savannah River Company (WSRC) for the United States Department of Energy under Contract No. DE-AC09-89SR18035 and is an account of work performed under that contract. Neither the United States Department of Energy, nor WSRC, nor any of their employees makes any warranty, expressed or implied, or assumes any legal liability or responsibility for the accuracy, completeness, or usefulness, of any information, apparatus, or product or process disclosed herein or represents that its use will not infringe privately owned rights. Reference herein to any specific commercial product, process, or service by trademark, name, manufacturer or otherwise does not necessarily constitute or imply endorsement, recommendation, or favoring of same by WSRC or by the United States Government or any agency thereof. The views and opinions of the authors expressed herein do not necessarily state or reflect those of the United States Government or any agency thereof. 


\section{DISCLAIMER}

Portions of this document may be illegible in electronic image products. Images are produced from the best available original document. 
Author:

M. S. Rabin

August 1994

Westinghouse Savannah River Company

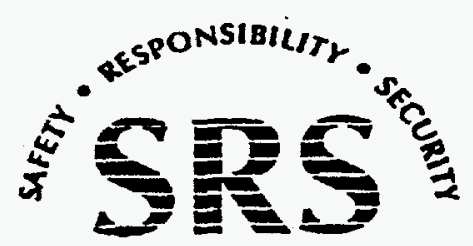


Document: WSRC-TR-93-451

Title: $\quad$ Pre-Title I Safety Evaluation for the Retrieval Operations of Transuranic Waste Drums in the Solid Waste Disposal Facility (U)

Task Plan: $\quad$ SRT-EAG-93-8005

Approvals:

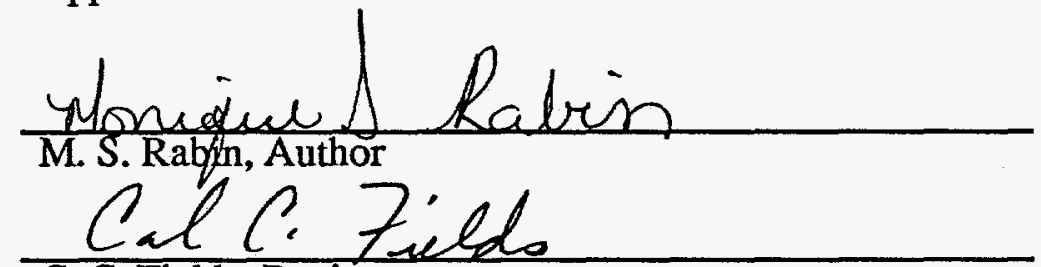

C. C. Fields, Reviewer

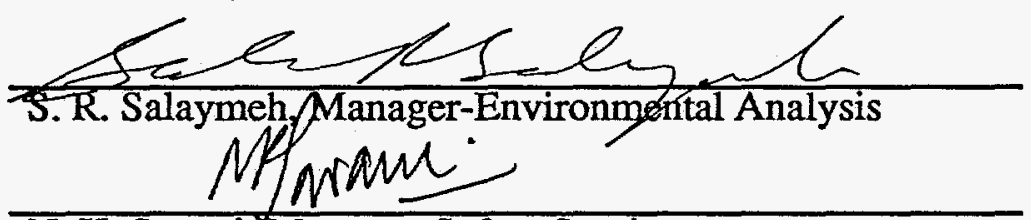

N. K. Savani, Manager-Safety Services

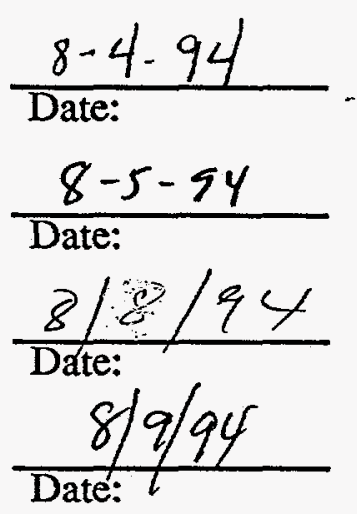




\section{ACKNOWLEDGMENTS}

Development of the Fault Tree Analysis provided in this evaluation was performed by E. V. Browne of the Waste \& Environmental Safety Technology Section, Savannah River Technology Center.

D. Cramer, of the Process Safety Technology Section, developed the uncertainty analysis provided in Appendix B of this report. 


\begin{abstract}
Phase I of the Transuranic (TRU) Waste Facility Line Item Project includes the retrieval and safe storage of the pad drums that are stored on TRU pads 2-6 in the Solid Waste Disposal Facility (SWDF). Drums containing TRU waste were placed on these pads as early as 1974. The pads, once filled, were mounded with soil. The retrieval activities will include the excavation of the soil, retrievai of the pad drums, placing the drums in overpacks (if necessary) and venting and purging the retrieved drums. Once the drums have been vented and purged, they will be transported to other pads within the SWDF or in a designated area until they are eventually treated as necessary for ultimate shipment to the Waste Isolation Pilot Plant in Carlsbad, New Mexico.

This safety evaluation provides a bounding assessment of the radiological risk involved with the drum retrieval activities to the maximally exposed offsite individual and the colocated worker. The results of the analysis indicate that the risk to the maximally exposed offsite individual and the co-located worker using maximum frequencies and maximum consequences are within the acceptance criteria defined in WSRC Procedural Manual 9Q.

The purpose of this evaluation is to demonstrate the incremental risk from the SWDF due to the retrieval activities for use as design input only. As design information becomes available, this evaluation can be revised to satisfy the safety analysis requirements of DOE Orders 4700 and 5480.23 .
\end{abstract}




\section{LIST OF ACRONYMS and ABBREVIATIONS}

$\begin{array}{ll}\text { AEC } & \text { Atomic Energy Commission } \\ \text { CFR } & \text { Code of Federal Regulations } \\ \text { COBRA } & \text { Computerized Operations Burial Records Analysis } \\ \text { ELLT } & \text { Engineered Low Level Trench } \\ \text { FDC } & \text { Functional Design Criteria } \\ \text { DOE } & \text { United States Department of Energy } \\ \text { DOT } & \text { United States Department of Transportation } \\ \text { HEPA } & \text { High Efficiency Particulate Air } \\ \text { HP } & \text { Health Protection } \\ \text { ICRP } & \text { International Council on Radiation Protection } \\ \text { INEL } & \text { Idaho National Engineering Laboratory } \\ \text { LATF } & \text { Low Activity TRU Facility } \\ \text { LFL } & \text { Lower Flammability Limit } \\ \text { LLRWDF } & \text { Low Level Radioactive Waste Disposal Facility } \\ \text { msl } & \text { Mean Sea Level } \\ \text { MWMF } & \text { Mixed Waste Management Facility } \\ \text { pSig } & \text { Pounds per square inch gage } \\ \text { RCRA } & \text { Resource Conservation and Recovery Act } \\ \text { SAR } & \text { Safety Analysis Report } \\ \text { SNM } & \text { Special Nuclear Materials } \\ \text { SRF } & \text { Source Reduction Factor } \\ \text { SRS } & \text { Savannah River Site } \\ \text { SRTC } & \text { Savannah River Technology Center } \\ \text { SWDF } & \text { Solid Waste Disposal Facility } \\ \text { TRU } & \text { Transuranic } \\ \text { USQ } & \text { Unreviewed Safety Question } \\ \text { ucl } & \text { Upper Confidence Limit } \\ \text { v/v } & \text { volume/volume } \\ \text { WHC } & \text { Westinghouse Hanford Company } \\ \text { WIPP } & \text { Waste Isolation Pilot Plant } \\ \text { WSRC } & \text { Westinghouse Savannah River Company } \\ & \end{array}$




\section{Table of Contents}

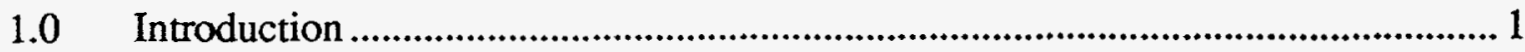

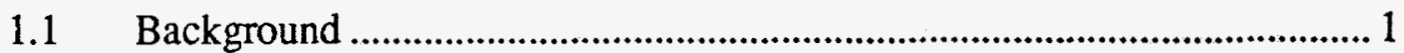

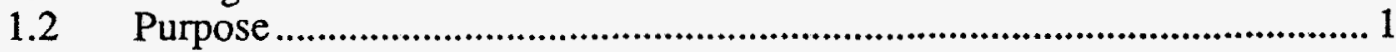

2.0 Retrieval Storage Pad Configuration Description .................................................. 2

2.1 Location of TRU Pads........................................................................... 3

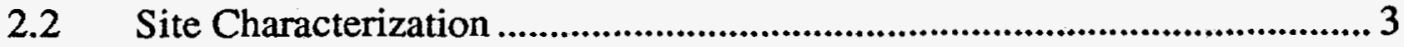

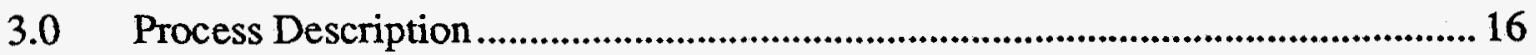

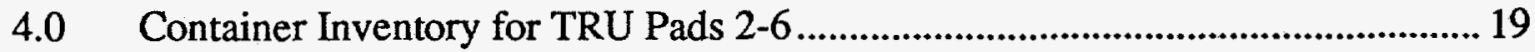

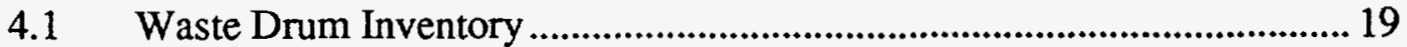

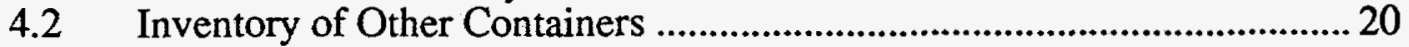

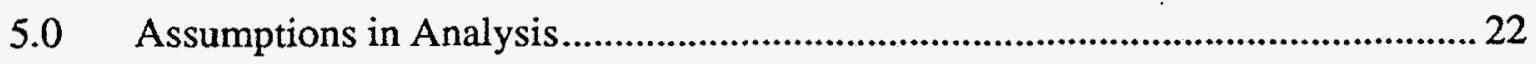

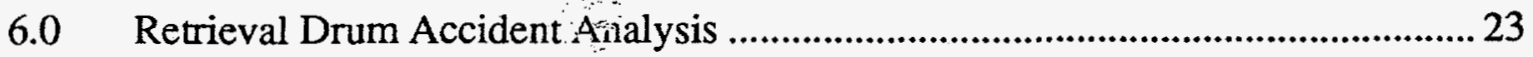

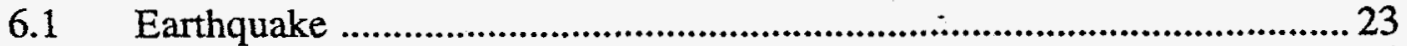

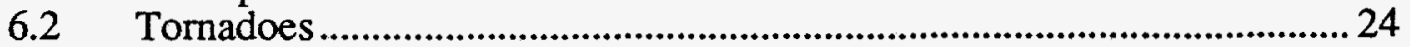

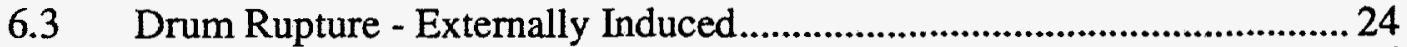

6.4 Equipment/Vehicle Collision .................................................................... 26

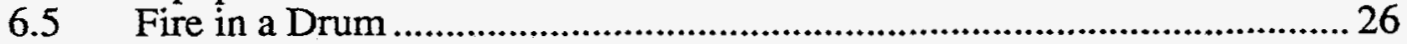

6.6 Deflagration of a Drum ........................................................................ 27

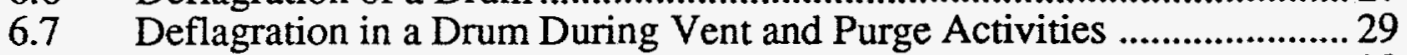

6.8 Deflagration Due to Solvents in the Drums ............................................... 30

6.9 Bulging and Severly Corroded Drums .......................................................... 31

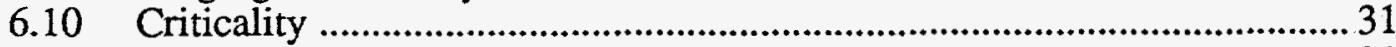

6.11 Storage of Retrieved Vented Drums ................................................... 31

7.0 Accident Analysis for Other Containers ........................................................ 34

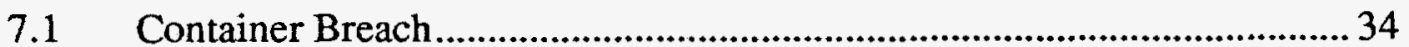

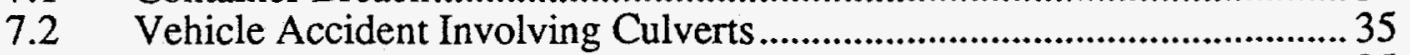

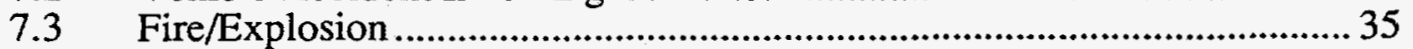

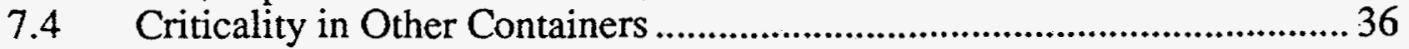

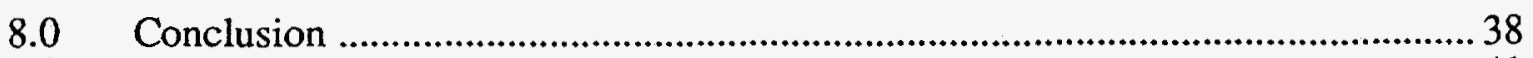

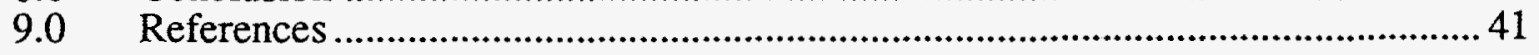




\section{List of Figures}

Figure 2-1. Container Arrangement for TRU Pad 2 - Layer 1 ........................................ 4

Figure 2-2 Container Arrangement for TRU Pad 2 - Layer 2 ..................................... 5

Figure 2-3. Container Arrangement for TRU Pad 3 - Layer 1 ......................................6 6

Figure 2-4. Container Arrangement for TRU Pad 3 - Layer 2 .................................. 7

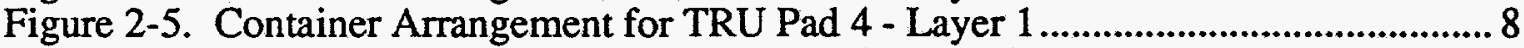

Figure 2-6. Container Arrangement for TRU Pad 4- Layer 2 .......................................... 9

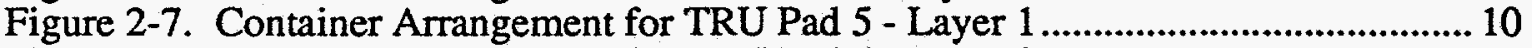

Figure 2-8. Container Arrangement for TRU Pad 5 - Layer 2 ......................................... 11

Figure 2-9. Container Arrangement for TRU Pad 6- Layer 1 ...................................... 12

Figure 2-10. Container Arrangement for TRU Pad 6 - Layer 2 ....................................... 13

Figure 2-11. Savannah River Site Map ................................................................... 14

Figure 2-12. TRU Pad Locations ............................................................................. 15

Figure 3-1. Flow Diagram of TRU Retrieval Process .................................................... 18

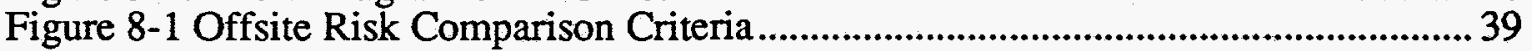

Figure 8-2 Onsite Risk Comparison Criteria ........................................................... 40

\section{List of Tables}

Table 4-1. COBRA Entries with Pu-238 Quantities Above 20 Curies ........................... 21

Table 4-2. Estimated Inventories of Waste Containers Stored on TRU Pads 2-6

Which Will Not be Retrieved

Table 6-1. Consequence and Risk Summary for Postulated Events .............................. 33

Table 7-1 Consequence and Risk Summary for Postulated Events for Culvert Movement

\section{Appendices}

Appendix A - Fault Tree Analysis For Drum Deflagration .....................................A-1

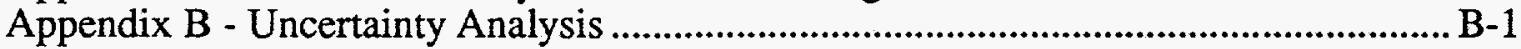

Appendix C - Calculation of Frequency for Second Drum Deflagration ..................... C-1 


\subsection{Introduction}

\subsection{Background}

In 1970 the U. S. Atomic Energy Commission (AEC) defined Transuranic (TRU) waste as a separate waste category and declared that it must be stored in a form that is retrievable as contamination-free packages designed to last 20 years pending decisions on permanent disposal. The Waste Isolation Pilot Plant (WIPP) in Carlsbad, New Mexico, is a research and development facility designed to demonstrate the safe and environmentally acceptable disposal of TRU waste from national defense programs. This research program has established the packaging criteria for permanent disposal of TRU waste.

The Savannah River Site (SRS) is one of the U. S. Department of Energy (DOE) sites that generate and store TRU waste from national defense programs. This waste was stored in steel boxes, drums, and drums within culverts which were placed on concrete slabs (Pad 1 is asphalt), called TRU pads. Within the Solid Waste Disposal Facility (SWDF) at SRS, there are 19 TRU pads. Pads 1-6, the earliest pads, received waste beginning in the early 1970 's. Once the earlier pads were filled, the pads were covered with a tarp and mounded with soil. The practice of mounding the pads was stopped prior to completing the earth cover over pad 6.

Future disfossal of mounded SRS TRU waste will require retrieving and treating it as necessary for shipment to WIPP or disposition of the drums for onsite disposal as low-level waste. Phase I of the retrieval project consists of providing the equipment necessary to safely retrieve, sample, vent, purge, and overpack the drums (not in culverts) from the mounded TRU waste pads. Pad 1 is not included in Phase I because no pad drums were placed on this pad (Barber, Stumbaugh. 1992).

\subsection{Purpose}

This document provides the preliminary safety evaluation of retrieval activities to be used as input into Title I design. The purpose of this evaluation is to demonstrate the incremental risk from the SWDF due to the retrieval activities is acceptable for use as design input only. This document is not intended to satisfy the requirements for a Preliminary Safety Analysis as required by DOE Orders 4700 and 5480.23. In 1991 an evaluation of the risks associated with the retrieval of buried TRU waste drums was performed (Ebra-Lima 1991) based on project descriptions and inventory information available at that time. This evaluation will supersede the 1991 evaluation.

The project information provided for input into the safety analysis included discussions and descriptions of drum retrieval, movement, venting, etc. The movement of other containers (i.e. culverts, boxes, casks, etc.) may be necessary during the retrieval of the drums. Evaluation of the movement of other containers is provided based on assumptions for the number of container movements, the method of movement, and an assumed inventory distribution based on the Computerized Operations Burial Records Analysis (COBRA) database.

This evaluation is limited to the radiological risks involved with retrieval of the TRU drums on pads 2-6. The radiological risks, however, are considered to be bounding from an accidental release standpoint. Liquid waste was prohibited from being placed in the drums stored on the TRU pads; waste placed in the drums consisted of contaminated clothing, small lab equipment, plastics, contaminated tools, etc. Because of the relatively small volume of waste stored in each drum, risks to the co-located worker and offsite individual from an airborne release of nonradiological material was not considered in the postulated accident scenarios. 


\subsection{Retrieval Storage Pad Configuration Description}

The drums involved in the retrieval process are stored on TRU pads 2-6 in the Solid Waste Disposal Facility (SWDF). Generators of the wastes in the drums primarily included F-Area, HArea, and the Savannah River Technology Center (SRTC). The first group of drums was placed on these pads in late 1974. These drums have a design storage life of twenty years (Barradale 1993). Other waste containers, such as concrete culverts, concrete boxes, and carbon steel boxes, are stored on TRU pads 2-6, but will not be retrieved (i. e. not sampled, vented purged, nor overpacked) as part of this process. Movement of some of these containers may be necessary to obtain access to the drums.

TRU pads 2-6 are essentially concrete slabs which are sloped to sumps. The approximate dimensions of TRU pads 3-6 are 60 feet by 150 feet. The approximate dimensions of TRU pad 2 are 50 feet by 125 feet. Waste containers were placed on the pads in the configuration shown in Figures 2-1 through 2-10. Drums were usually stacked two high, while the concrete culverts and most boxes were stored one high. Aluminum angles were used as stacking stabilizers between the first and second tiers of drums. Once each pad was filled to capacity with the waste containers, a plastic tarp was placed over the waste containers. Soil was then placed over the waste-filled pad, which resulted in a mounded burial, with the exception of TRU pad 6 . The placement of soil over TRU pad 6 was not completed; only the sides of this pad are covered with soil.

No permanent structures will be erected as part of the retrieval activities. A temporary weather cover will be constructed over each pad during retrieval activities. This weather cover will be designed to protect the pad from rain and allow operations to continue during poor weather conditions. The design of the weather cover will allow an inside clearance height capable of accommodating forklifts, vacuum systems and small cranes (Barradale 1993).

A contamination control hut will be constructed within the weather cover over the particular area of drums being retrieved to prevent the spreading of potential contamination. This hut will be equipped with a ventilation system consisting of low efficiency inlet filter and a mechanical ventilator which will force the exhaust air through a HEPA filter. The contamination control hut will be maintained at negative pressure during retrieval activities and will be equipped with airlocks to allow personnel to enter and exit without disrupting the ventilation system. It is assumed that the contamination control hut will not be designed to meet the design criteria for a nuclear facility and is, therefore, not credited for mitigation in this safety evaluation .

A mobile vacuum system will be used during the retrieval activities to remove and collect loose soil from around the waste containers. The hopper and motor of the system will be located outside the contamination control hut, while the vacuum hose will penetrate the hut wall. The hose will be maneuvered using an electro-mechanical manipulator. The exhaust outlet for the vacuum will be HEPA filtered (Barradale 1993).

A vent and purge station will be constructed and relocated with each move of the contamination control hut. Although no specifications for the vent and purge station currently exist, for purposes of this analysis, it is assumed that the following design requirements apply:

- A non sparking drill will be used to penetrate the drum lid, and will be operated from a remote distance.

- A chamber surrounding the drill bit will be sealed to the drum surface and a vacuum will be pulled on the chamber during drilling operations.

- The chamber system will be equipped with a filter to adsorb hazardous vapors and contaminants which may be present. 
- A nitrogen system will be provided to purge the drum once the lid is penetrated.

- A HEPA/carbon composite filtered vent will be installed in the drum lid to allow flammable gases to escape.

\subsection{Location of TRU Pads}

The TRU pads are located in E Area of the SRS within the SWDF (Figure 2-11). The TRU pads are located in the southeast corner of the area designated at 643-7E as shown in Figure 2-12.

\subsection{Site Characterization}

\subsubsection{Flooding}

The SWDF is located outside of the 100 year floodplain.

In October of 1990, heavy rains over a period of several days caused some flooding in the SWDF. The flooding was most severe in Engineered Low Level Trench (ELLT) 4, in the northeast corner of the 643-7E area. ELLT 4 was a large depression, approximately 20 feet deep, and adjacent to the Mixed Waste Management Facility (MWMF) which was closed under the Resource Conservation and Recovery Act (RCRA) with a clay cap. The impermeable cover over the adjacent areas and the low elevation of ELLT 4 enhanced the vulnerability to flooding of ELLT 4 . During this same period of heavy rains, no flooding conditions were observed near the TRU pads 2-6.

Run-off control in the SWDF is accomplished by using slope to drain water to a set of drainage ditches in and around the facility. These ditches transport water to two sediment retention ponds, which discharge to both Upper Three Runs Creek and Fourmile Branch. The SWDF is on a topographic high point of the SRS, at an elevation of approximately 290 feet msl. Since the TRU pads being excavated are above ground level, flooding of pads 2-6 is not expected.

\subsubsection{Access Roads}

Pads 2-6 are located adjacent to SWDF access roads traveled by personnel working within the SWDF. Various construction activities may be in progress during the retrieval activities, which may increase the traffic loads on the access roads. It is assumed that, prior to any retrieval activities, temporary barriers will be strategically placed to protect the TRU pads from potential vehicle accidents involving non-retrieval vehicles. 


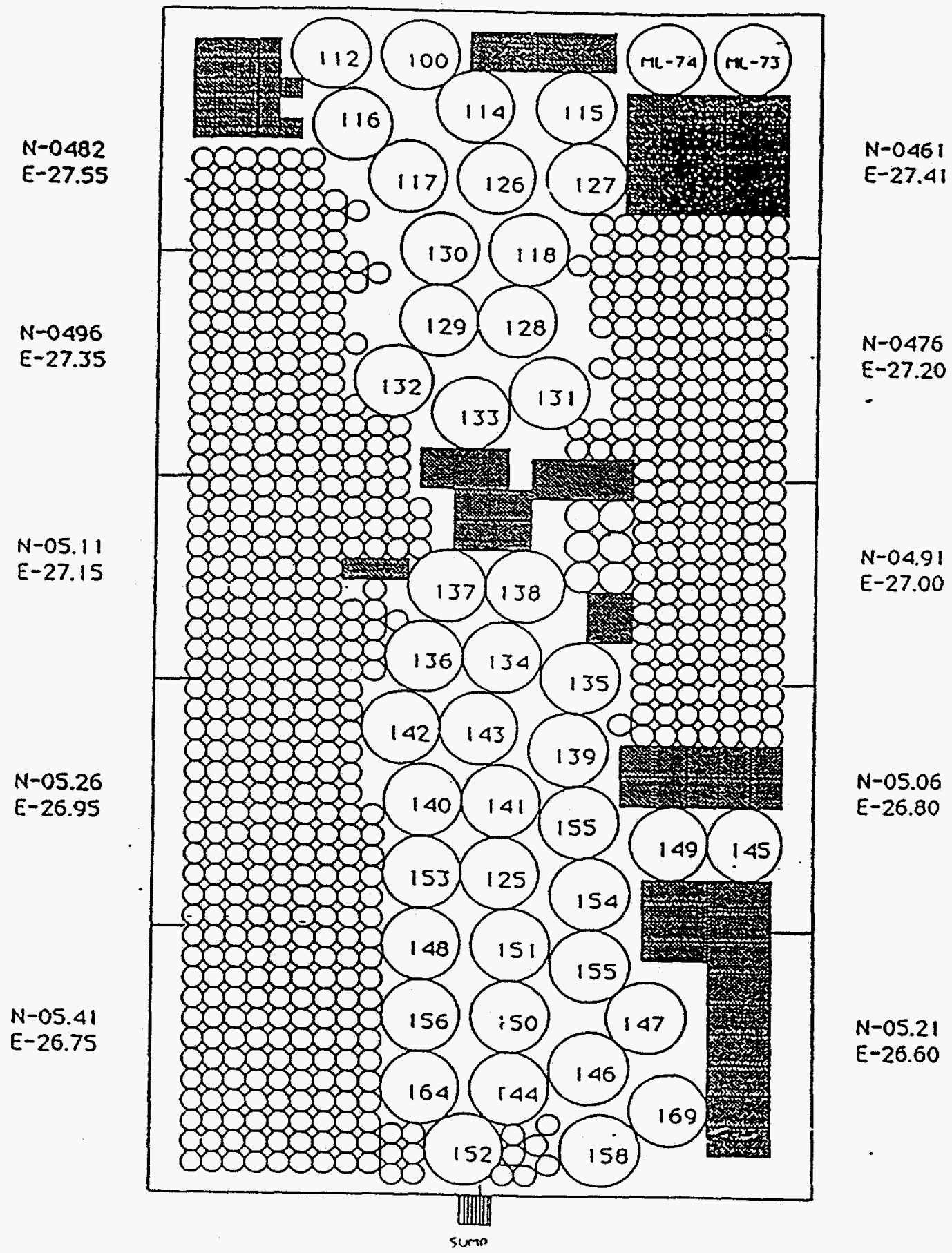

Figure 2-1. Container Arrangement for TRU Pad 2 - Layer 1 


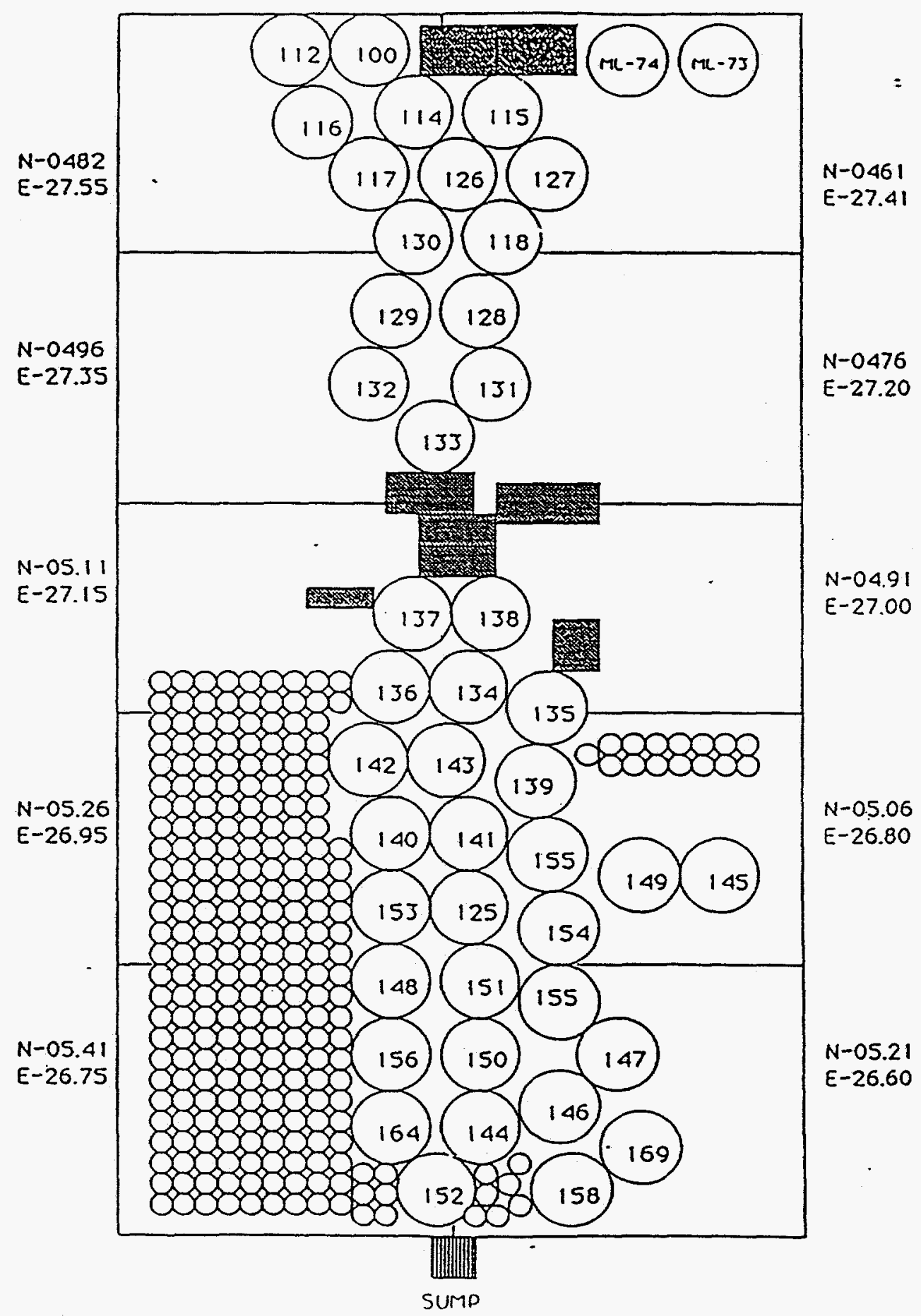

Figure 2-2 Container Arrangement for TRU Pad 2 - Layer 2 
WSRC-TR-93-451

Rev. 2

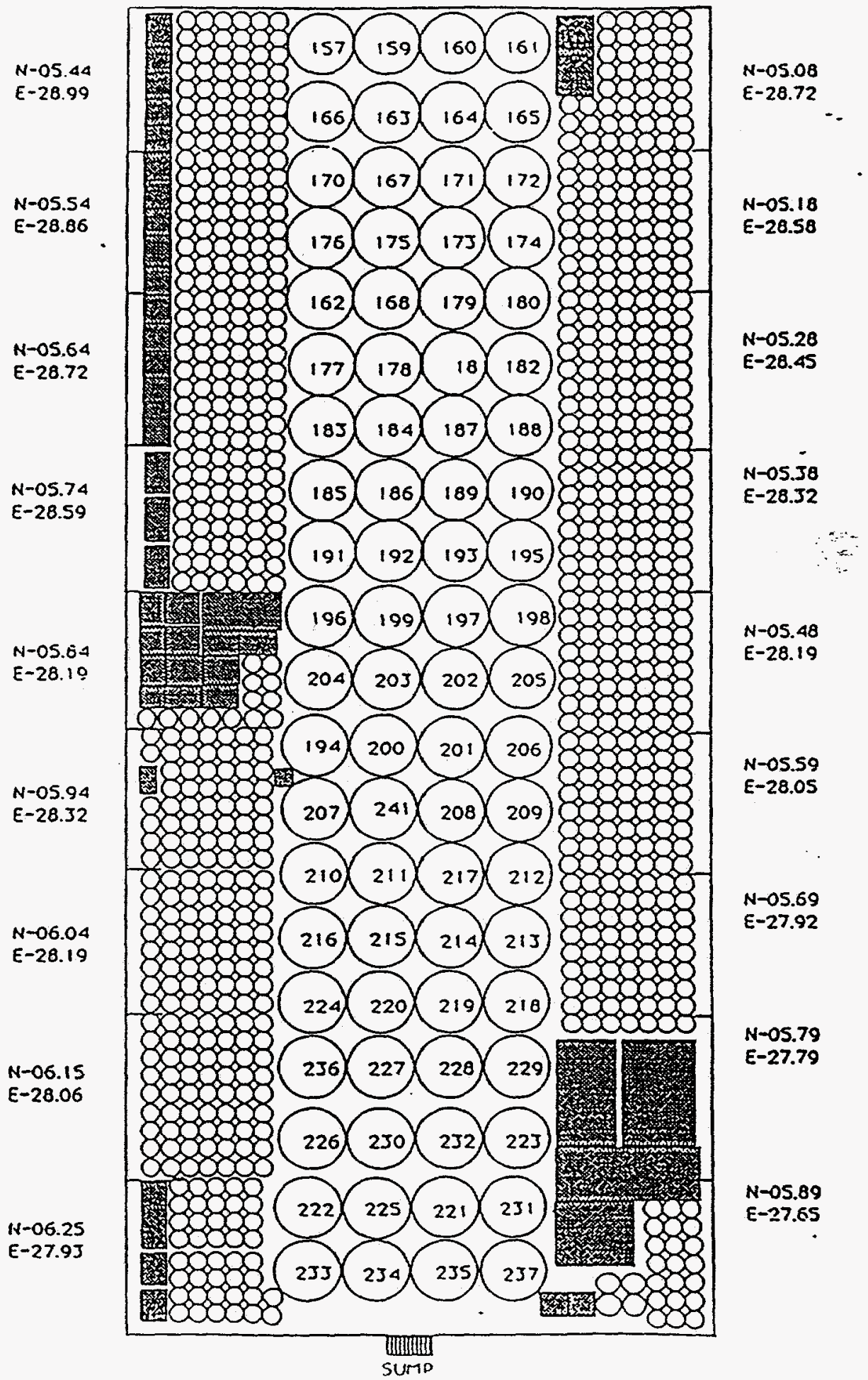

Figure 2-3. Container Arrangement for TRU Pad 3 - Layer 1 
WSRC-TR-93-451

Rev. 2

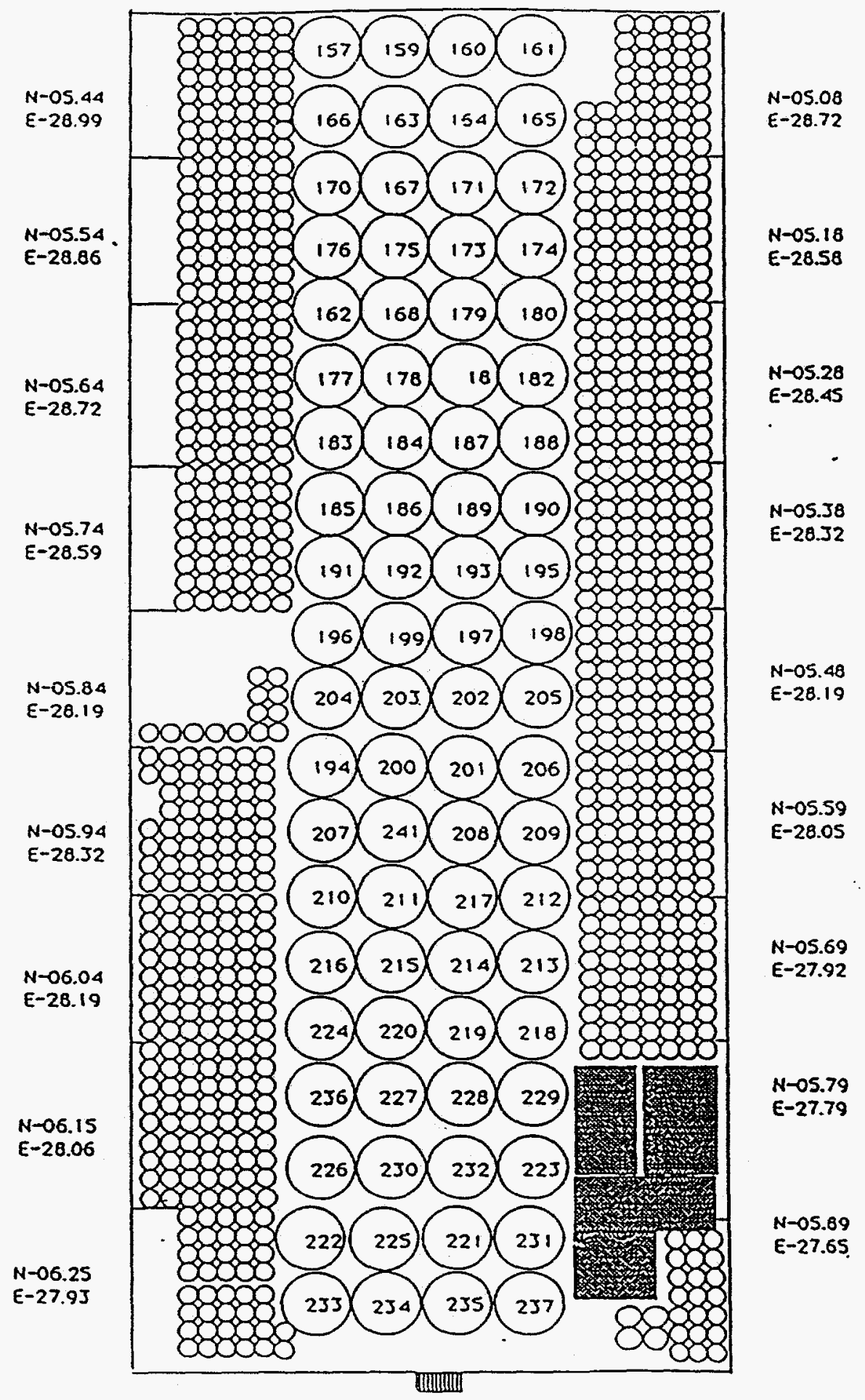

Figure 2-4. Container Arrangement for TRU Pad 3 - Layer 2 
WSRC-TR-93-451

Rev. 2

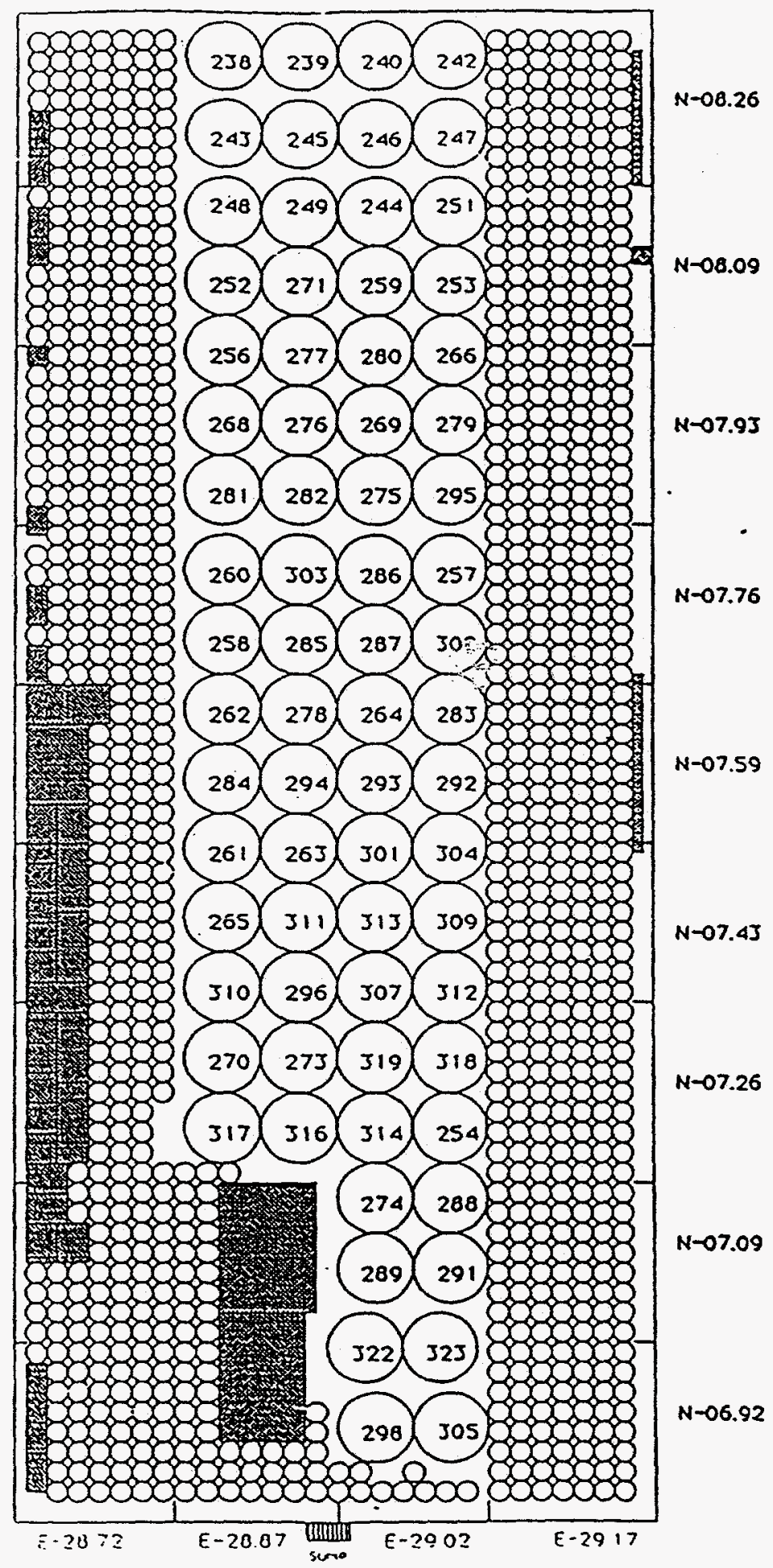

Figure 2-5. Container Arrangement for TRU Pad 4 - Layer 1 


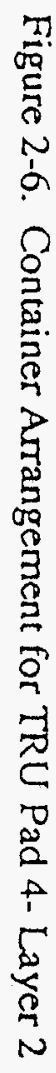

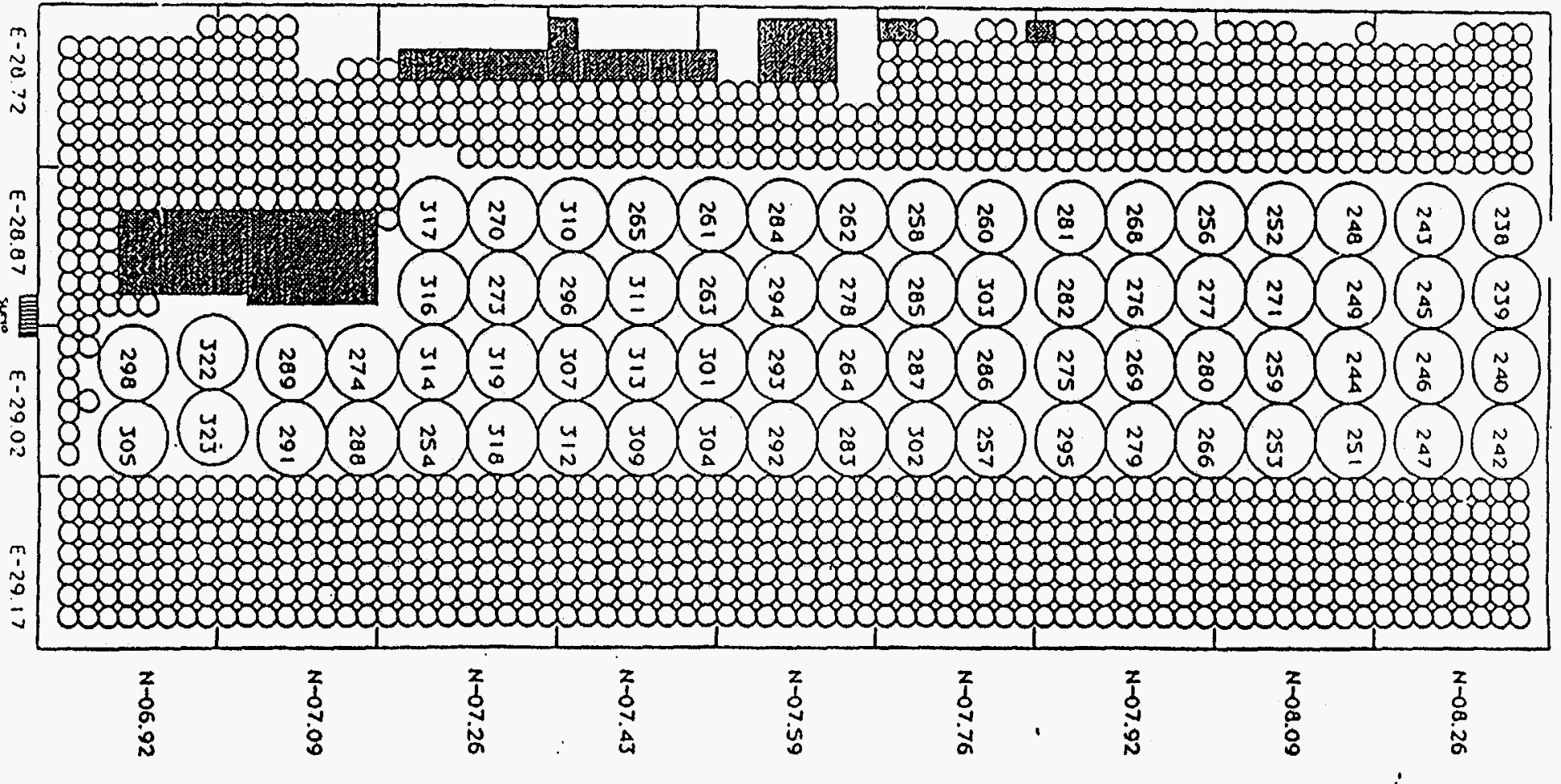


WSRC-TR-93-451

Rev. 2

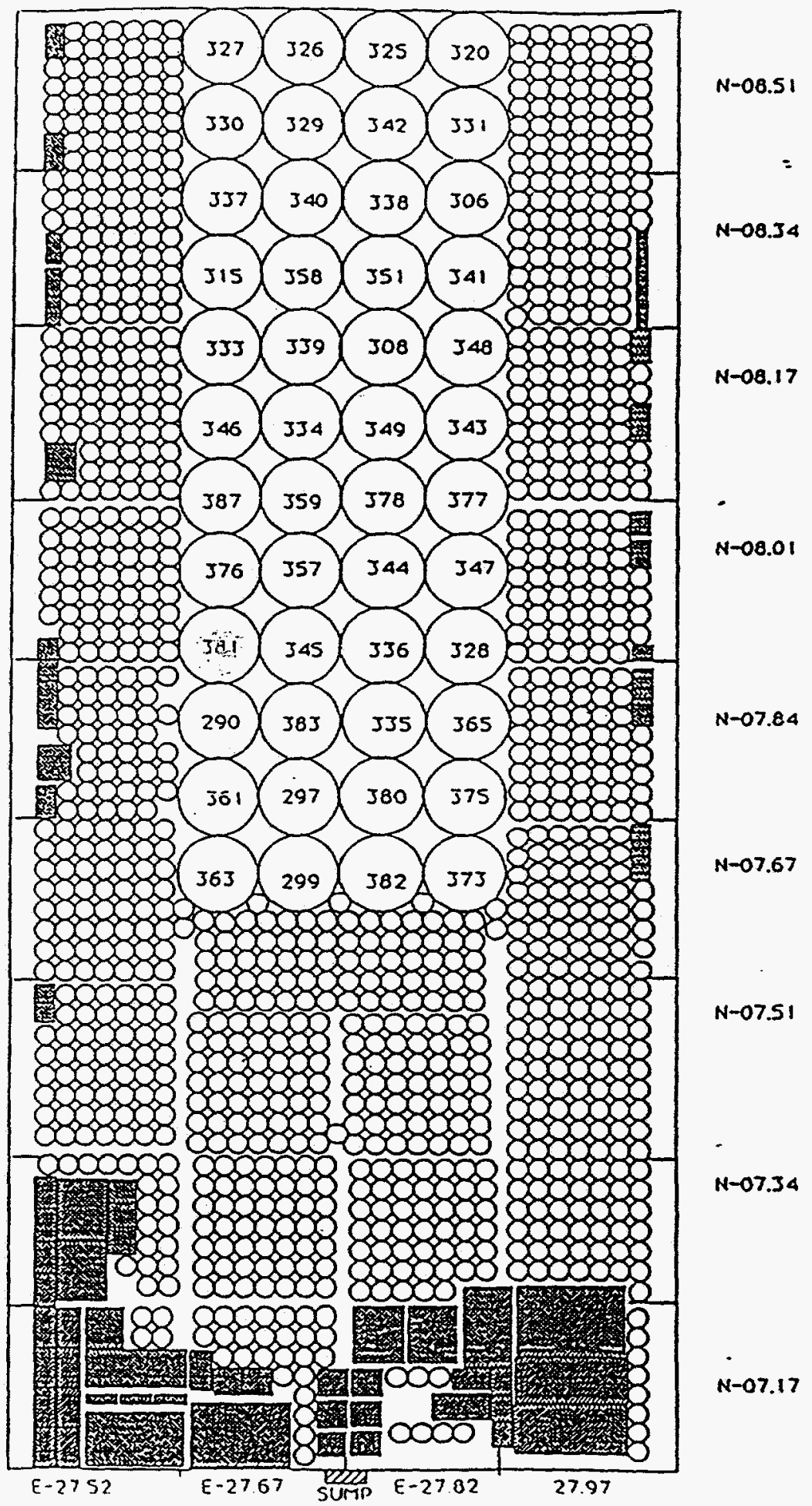

Figure 2-7. Container Arrangement for TRU Pad 5 - Layer 1 
WSRC-TR-93-451

Rev. 2

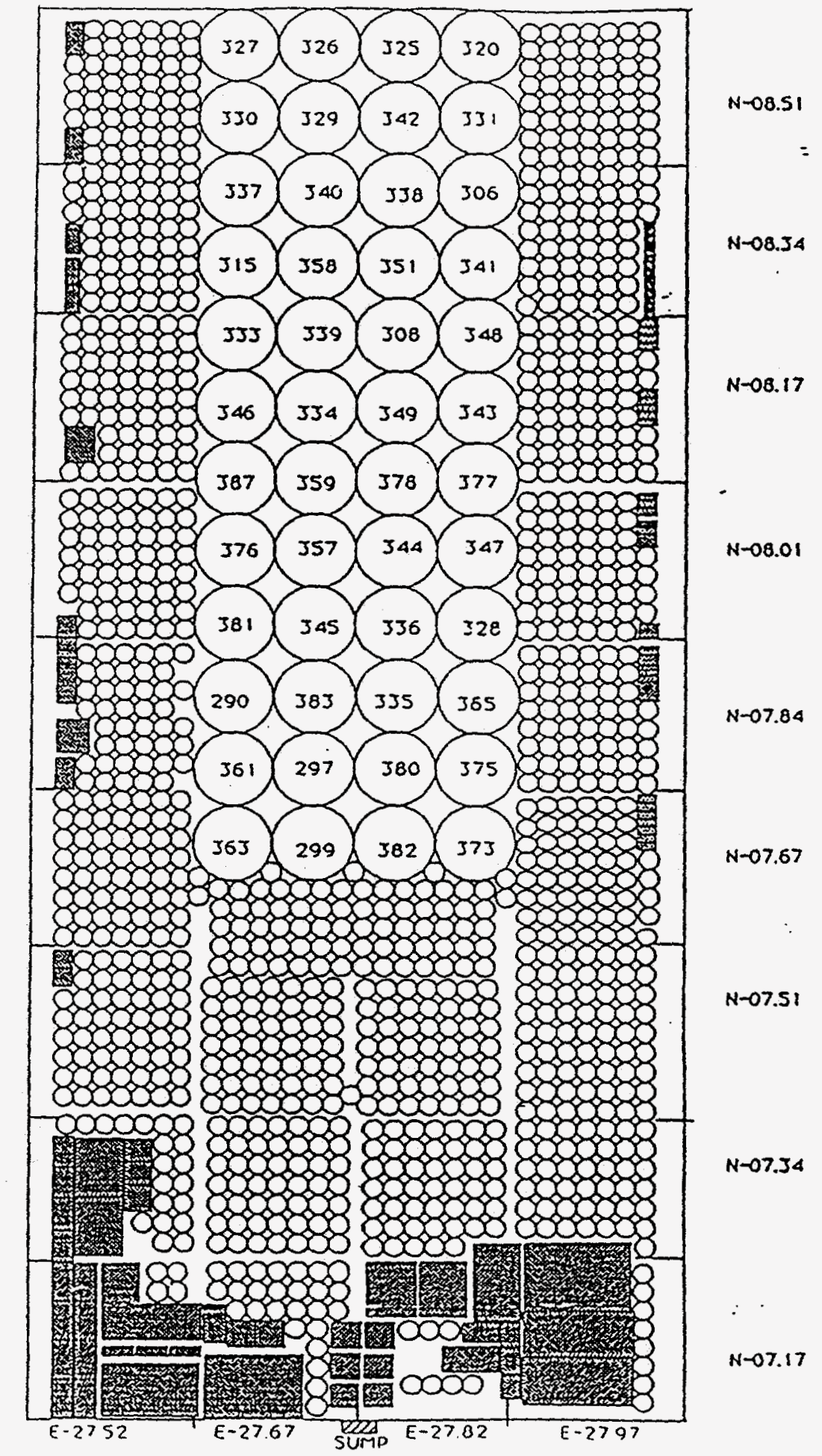

Figure 2-8. Container Arrangement for TRU Pad 5 - Layer 2 
WSRC-TR-93-451

Rev. 2

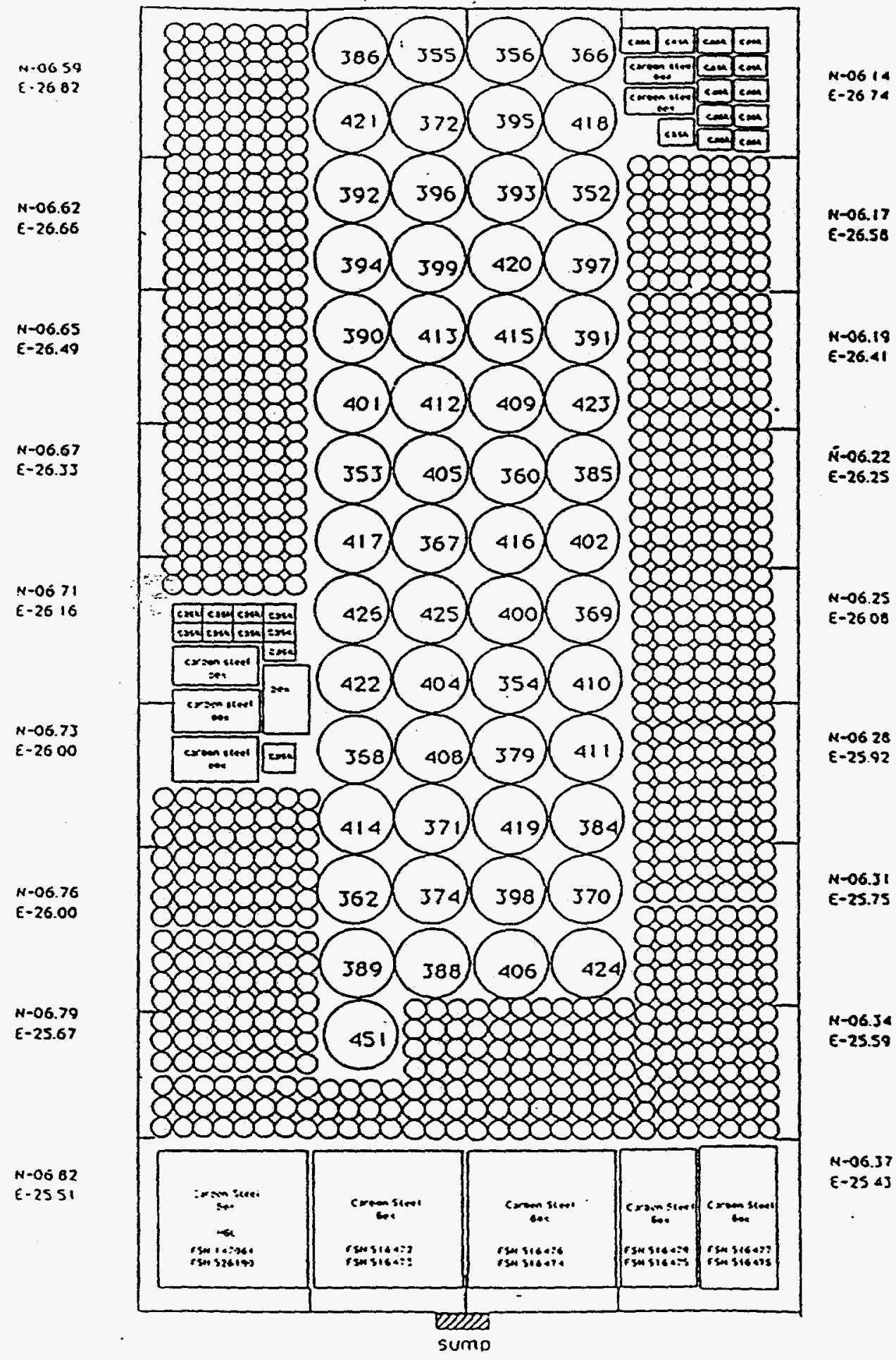

Figure 2-9. Container Arrangernent for TRU Pad 6- Layer 1 
WSRC-TR-93-451

Rev. 2

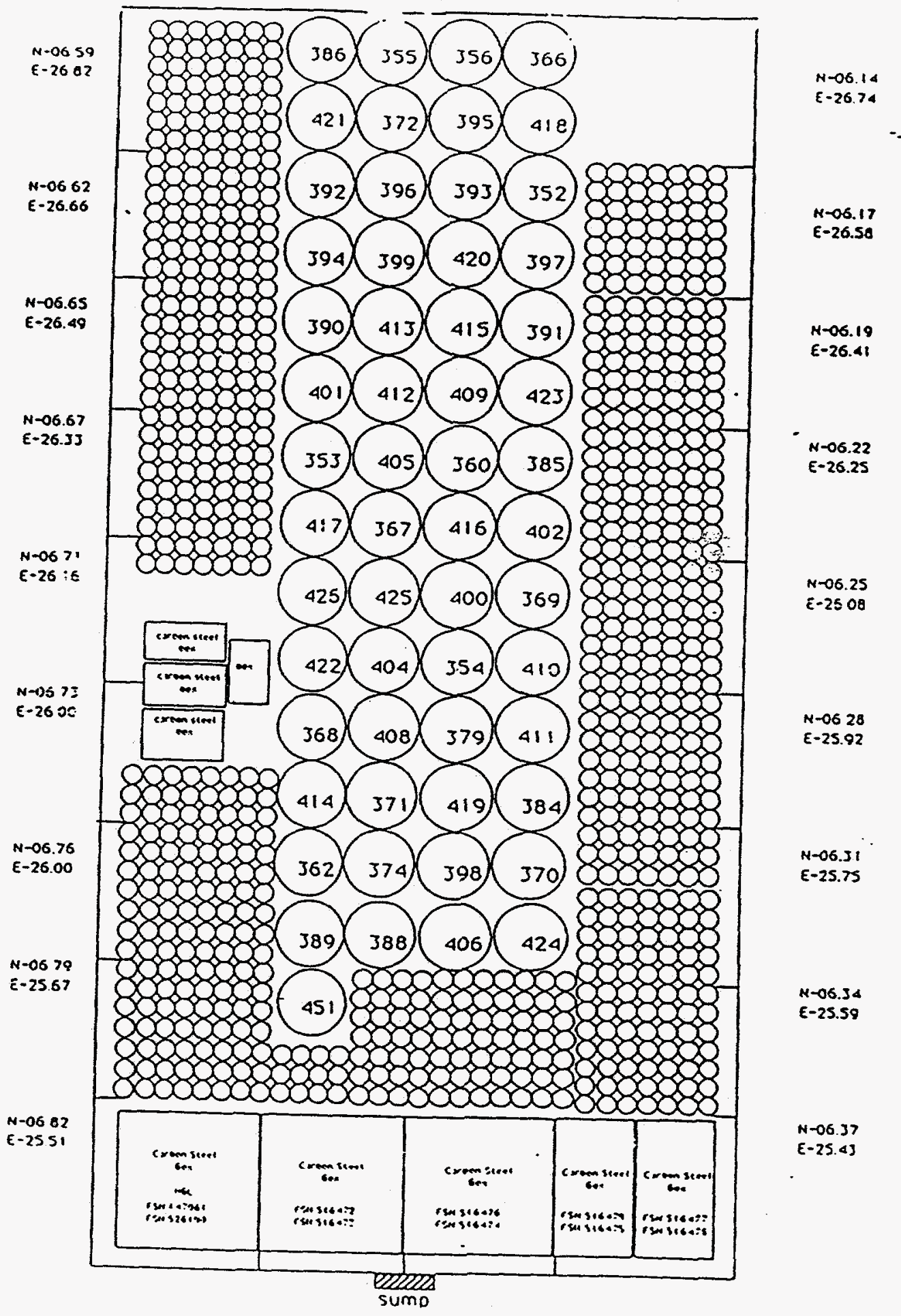

Figure 2-10. Container Arrangement for TRU Pad 6 - Layer 2 
TRU Waste Retrieval Process (SWDF)

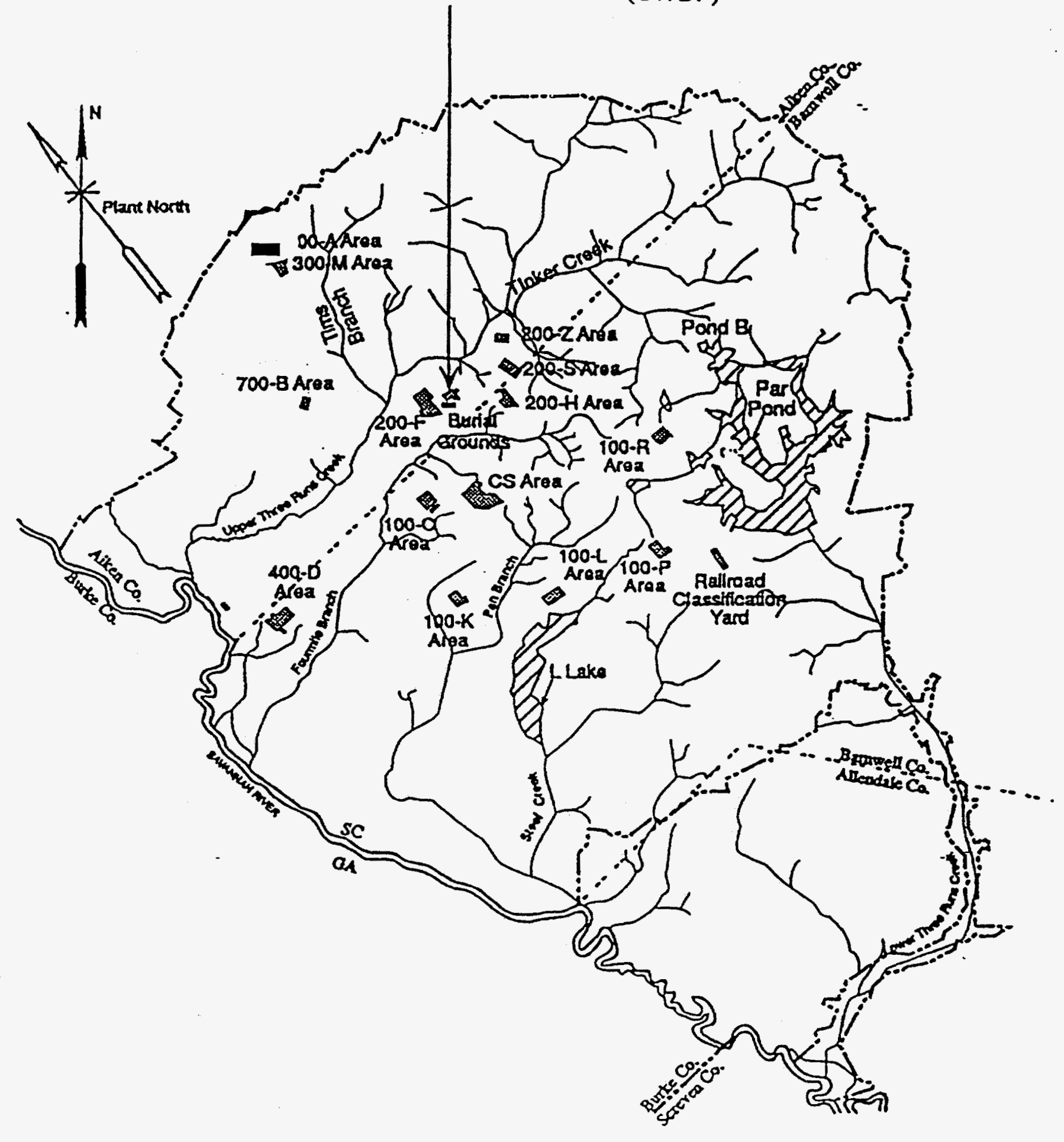

Figure 2-11. Savannah River Site Map 


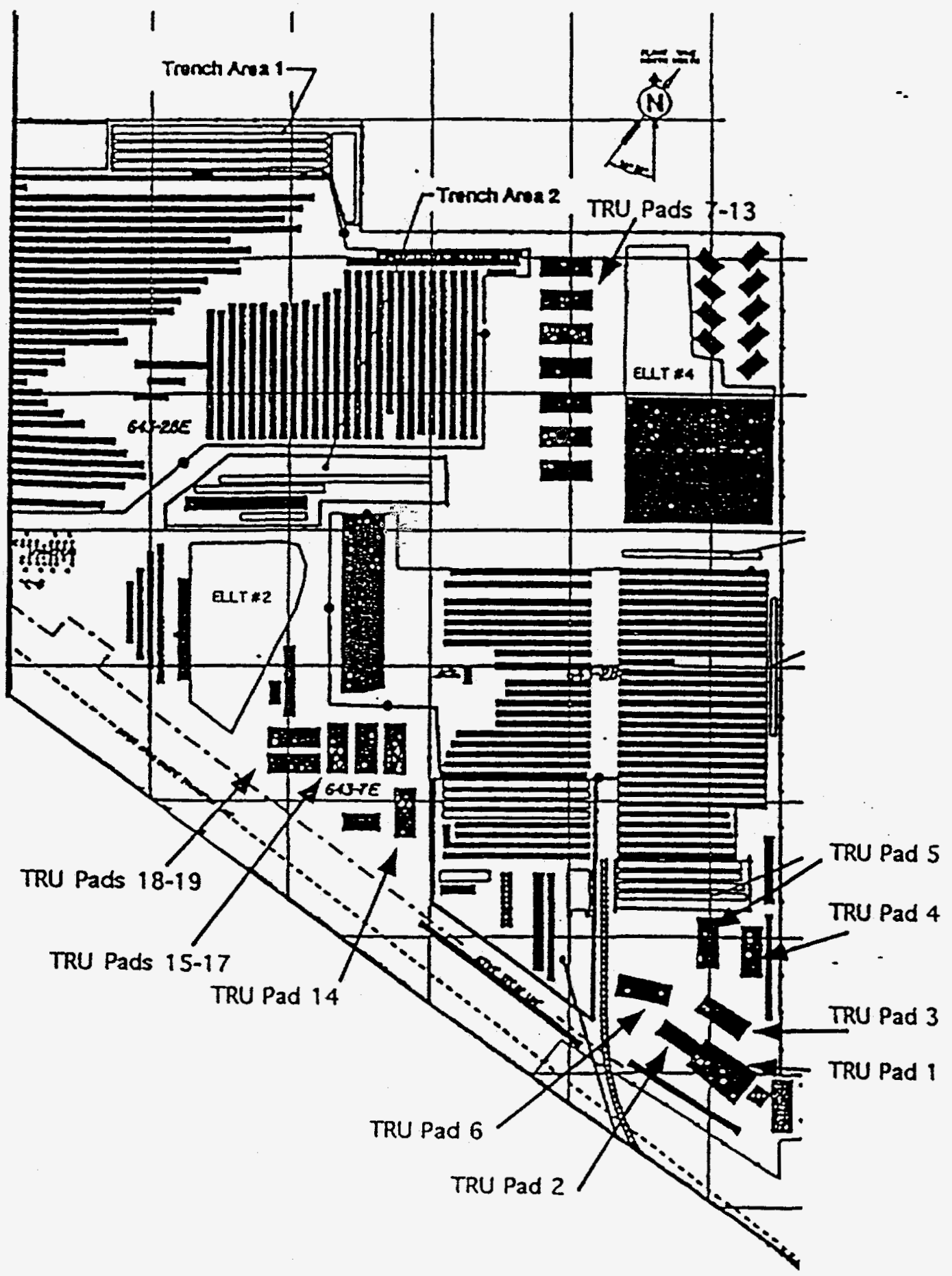

Figure 2-12. TRU Pad Locations 


\subsection{Process Description}

A description of the retrieval process, which is important to the safety analysis, is provided in this section. As Title I design has not been initiated, and process procedures have not been developed, the process description provided below has been developed from the Functional Design Criteria (WSRC 1993a), the Operational Baseline Document (Barradale 1993), and assumptions based on oral descriptions from project personnel. This safety evaluation is based on the assumed process description as summarized below. Figure 3-1 provides a simplified flow diagram of the retrieval process.

A Ground Penetrating Radar (GPR) survey of each pad will provide verification of the location of perimeter waste containers. The retrieval process begins by removing the soil from the mounded pads using a telescopic excavator to within approximately 2 feet of the containers. A weather cover will then be constructed over the excavated pad as well as erosion control barriers to control run-on from adjacent TRU pads. The telescopic excavator will then remove the next layer of soil down to approximately 6 to 12 inches from the containers in the area of the TRU pad where the first group of drums will be retrieved. Next, a contamination control hut will be constructed over the first area of containers to be retrieved. Within the contamination control hut, a vacuum hose will be mechanically manipulated to remove the loose soil from around the waste containers. The drums will be visually inspected for corrosion and bulging. A drum lifting device will be used to lift the drums and place them into drum overpacks. All drums will be overpacked unless the integrity of the drum being retrieved is comparable with the drum overpack as determined by visual examination.

Once a drum has been placed in a drum overpack, a forklift will transport the drum to the vent and purge station. Within the vent and purge station, the retrieved drum will be vented from a remote location by drilling a hole in the drum lid using a nonsparking drill. The headspace in the drums may then be sampled for hydrogen concentrations and Volatile Organic Compounds (VOCs). After sampling, the drum will be purged (if necessary) through a carbon/HEPA filter exhaust system and a filter will be placed on the retrieved drum. It is assumed that some type of fire suppression capability will be provided near the vent and purge system.

Once the drum has been vented and purged, the vented lid of the drum overpack will be secured. The drum will then be lifted from the vent/purge station by a forklift, which will carry the overpacked drum to the staging area. The staging area will provide temporary storage for an accumulation of overpacked and vented drums. Periodically, the drums in the staging area will be transported to a longer term storage area. Transportation of the drums from the staging area and storage of the drums in longer term locations are outside the scope of this safety evaluation.

The process rate for drum retrieval will be approximately one drum per hour (WSRC, 1993a). It is anticipated that at this rate, with allowance for field set-up, the retrieval activities will continue for 7 years. For purposes of this analysis, it is assumed that a maximum of 2,000 drums per year will be processed.

Drums which are observed to have severe corrosion or are observed to be bulging will be handled on a case-by-case basis. Special precautions shall be implemented to reduce the potential hazards of handling drums that are severely corroded or are observed to be bulging. For purposes of this analysis, severe corrosion shall mean corrosion such that the structural integrity of the drum cannot be assured and that routine lifting of the drum may result in loss of containment.

If necessary, other containers may be moved to gain access to the drums that will be retrieved. These containers include concrete culverts, steel boxes, and concrete casks, all of varying dimensions and weights. The concrete culverts are cylindrical containers with approximately 6inch reinforced concrete walls. The diameter of the culverts is approximately 7 feet, and each 
stands approximately 7 feet high. Each culvert holds a maximum of fourteen 55-gallon drums. Neither the drums nor the culverts were equipped with vents; the concrete would not be expected to entrap any gases.

The steel boxes and concrete casks stored on the TRU pads are of various dimensions. During placement of waste containers on TRU pads 2-6, standardization of waste containers, done for waste containers that are stored on other pads, was not practiced. Drawings are available for these waste containers. These drawings generally call for at least $3 / 8$ inch carbon steel containment, requiring string vents at the gaskets as the venting mechanism. Design weights of the containers vary from less than $1,000 \mathrm{lbs}$. to over several tons (DWG S4-6-189, S5-2-10296).

After visual inspection for container integrity, a forklift or crane will be used to move these containers. The containers will be stored on available pad space. It is assumed that no more than 100 containers (including black boxes, culverts, etc.) will be moved per year to gain access to the drums being retrieved. 


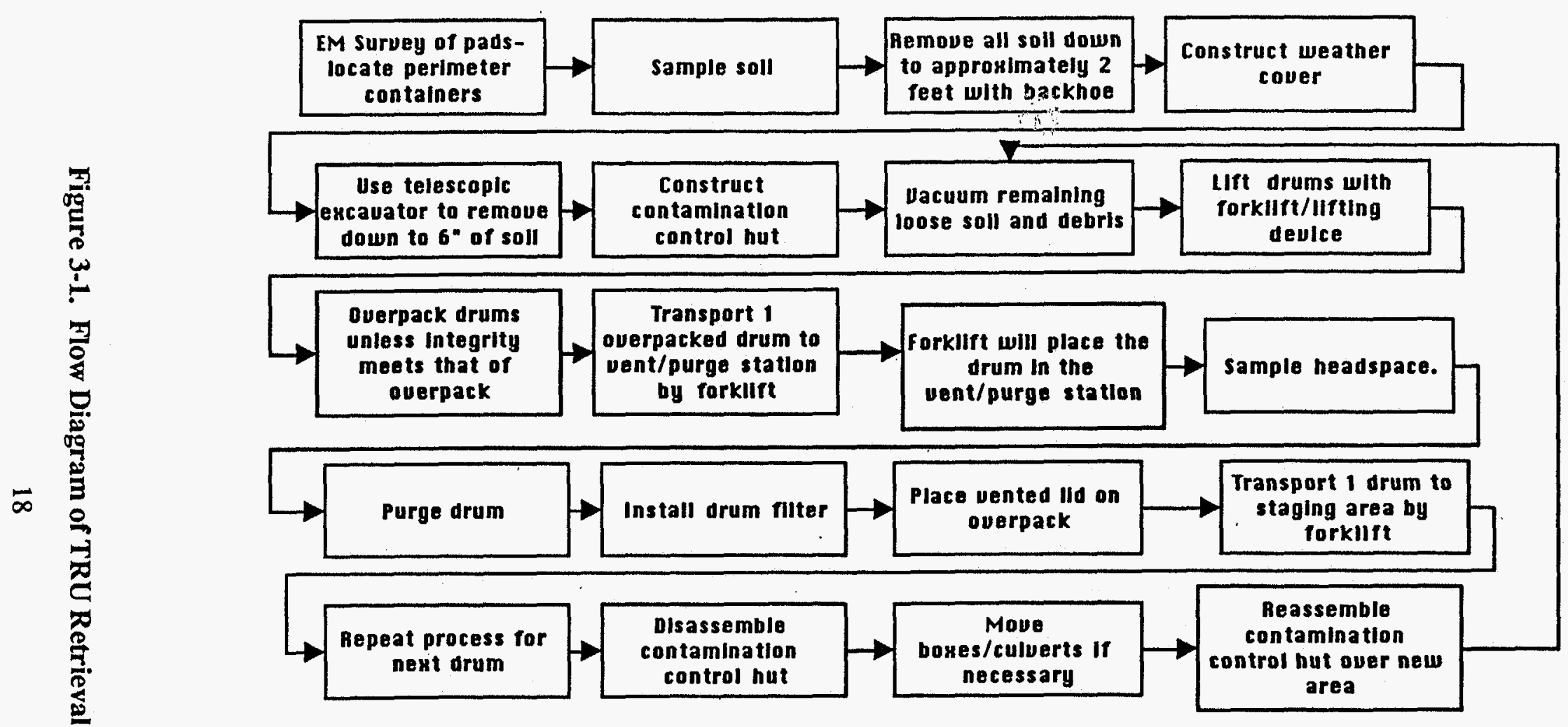

Figure 3-1 flow Diagram of ThU Retrieual Process 
WSRC-TR-93-451

Rev. 2 .

\subsection{Container Inventory for TRU Pads 2-6}

\subsection{Waste Drum Inventory}

Most of the waste that was stored on pads 2-6 was generated in H-Area, F-Area, and SRTC. Some generators would dispose of wastes by filling 5 gallon containers lined with polyethylene bags, assaying each filled bag, and placing the bags inside of a 90-mil polyethylene lined drum (55 or 83 gallons). Each filled bag is considered a cut. Other generators placed a single polyethylene bag filled with waste, of which the inventory was calculated based on smear tests, into a drum with the same type of liner as mentioned above. Any drums exceeding 0.5 curies were required to be placed inside concrete culverts (Fields 1993).

For each waste drum, a burial slip was required. The burial slip included information such as the type of waste, the volume of waste, the amount of selected radionuclides, the type of storage, and the disposal location coordinates. This information was entered into the Computerized Operations Burial Record Analysis (COBRA) database. Data stored within the COBRA database regarding inventory (and other factors) has become suspect based on the detection limits of the generator's assay equipment and errors that have been identified from reviewing various burial slips. The minimum detection level for Pu-238 in the TRU waste assay instrumentation for HB-Line was calculated to be 0.1 grams. In addition, the COBRA database printouts indicate that there are numerous pad drums which exceed the 0.5 curie limit located on pads 2-6.

Based on the detection limits of the assay equipment, it is assumed that each pad drum that was generated in HB-Line could contain up to 1.1 grams of $\mathrm{Pu}-238$ (approximately 20 curies). This assumption is based on the maximum number of waste "cuts" at the maximum gram level being placed in each drum (Fields 1993). HB-Line was a significant generator of waste that was stored on TRU pads 2-6; however, much of the waste generated in HB-Line was placed in culverts. COBRA records indicate that approximately $13 \%$ of the pad drums on TRU pads 2-6 were generated in HB-Line. Additionally, COBRA was reviewed to determine the number of pad drums which contain $\mathrm{Pu}-238$ from all generators. The result of the review indicates that $28 \%$ of the pad dums contain $\mathrm{Pu}-238$. For purposes of this analysis, it will be assumed that all generators that disposed of $\mathrm{Pu}-238$ waste in pad drums could have exceeded the 0.5 curie limit and that $28 \%$ of the pad drums have a $\mathrm{Pu}-238$ inventory of 20 curies. The purpose of this assumption is to bound the analysis of the TRU Retrieval activities and does not imply that all the Pu-238 drums exceed the operating limit for placing drums directly on the pad (i.e. exceed the $<0.5 \mathrm{Ci}$ limit).

In reviewing the COBRA database, 10 entries were identified as being pad drums (for pads 2-6) that exceed the 20 curie assumption for $\mathrm{Pu}$-238. These entries, however, are believed to represent the inventory of other pad containers such as steel boxes or casks. The associated coordinates for each of these entries identify several culverts or steel boxes (according to figures 2-1 through 2-10) within those areas. Verification that these entries represent the inventories for other containers (i.e. not pad drums) must be made prior to the retrieval activities taking place. A list of the entries above the 20 curie limit for Pu-238 and the associated recorded location are provided in Table 4-1.

The operational safety requirements (OSR) limit the amount of $\mathrm{Pu}-239$ fissile gram equivalents in each drum stored in the SWDF to less than 195 grams. The nuclear safety procedural limits of $<0.5$ curie for pad drums applies to all TRU isotopes. The majority of the Pu-239 contaminated waste was generated in F-Area, including FB-Line. Errors in the calculation of the Pu-239 mass of FB-Line generated waste have resulted in the exceedance of the OSR limits as well as the procedural limits. Summaries of the occurrence, as well as, evaluations prepared and actions taken indicate that the risk of criticality was not significantly increased (Shappell, 1993 and Chay, 1990). In addition, the final evaluation of this occurence indicates that the 20 curie Pu-238 assumption as 
described in the preceeding paragraph is still bounding for the waste drums stored directly on the TRU pads.

\subsection{Inventory of Other Containers}

For purposes of this evaluation, culvert, box and cask inventories were estimated using the COBRA database. $\mathrm{Pu}-238$ inventories were considered the bounding isotopes from a consequence standpoint. Using the COBRA data, the mean, maximum, and standard deviation for the Pu-238 inventory in casks, boxes, and miscellaneous containers were identified for pads 2-6. In addition, for all drums inside culverts, the mean, maximum, and standard deviations were identified by each pad. To estimate a conservative inventory to be used in this evaluation the $95 \%$ upper confidence limit (ucl) was computed for the containers on each pad. The pad with the highest $95 \%$ ucl for $\mathrm{Pu}-$ 238 was used as the bounding inventory for the accident scenarios.

For Pu-238, TRU pad 2 had the highest calculated $95 \%$ ucl in a drum inside a culvert. The calculated value was approximately 370 curies of $\mathrm{Pu}-238$.

This principle was also applied to estimate the inventory of the other containers stored on TRU pads 2-6. For $\mathrm{Pu}-238$, the $95 \%$ upper confidence limit was estimated to be approximately 740 curies.

$\mathrm{Pu}-239$ inventories were reviewed for use in the criticality assessment. The maximum recorded $\mathrm{Pu}-239$ inventory in a drum inside a culvert was 11.4 curies (equivalent to approximately 184 grams). The maximum recorded $\mathrm{Pu}-239$ inventory in all other containers (i.e., containers besides pad drums and drums inside culverts) was 302 grams.

The estimated inventory values for $\mathrm{Pu}-238$ and the maximum recorded $\mathrm{Pu}-239$ inventories are summarized in Table 4-2. These values are considered to be conservative estimates of inventories in the containers to be used for purposes of this analysis. 
Table 4-1. COBRA Entries with Pu-238 Quantities Above 20 Curies

\begin{tabular}{|llllll|}
\hline $\begin{array}{l}\text { COBRA } \\
\text { Printout } \\
\text { Observation } \\
\text { Number }\end{array}$ & $\begin{array}{l}\text { Pad } \\
\text { Number }\end{array}$ & $\begin{array}{l}\text { Quantity of } \\
\text { Pu-238 in } \\
\text { grams }\end{array}$ & Waste Description & $\begin{array}{l}\text { North } \\
\text { Coordinate }\end{array}$ & $\begin{array}{l}\text { East } \\
\text { Coordinate }\end{array}$ \\
\hline \hline 2291 & 3 & 1.1 & Glovebox furnace & N05.89 & E27.65 \\
2764 & 3 & 29.1 & Steel box & N06.25 & E27.93 \\
3177 & 4 & 1.7 & Sinter furnace & N07.09 & E28.72 \\
3452 & 4 & 2.2 & Cabinet Panels & N07.26 & E28.72 \\
5211 & 5 & 4.5 & RD-1 Dissolver & N07.34 & E27.52 \\
5213 & 5 & 2.1 & Cabinet Panels & N07.34 & E27.52 \\
5225 & 5 & 4.5 & RD-2 Dissolver & N07.34 & E27.52 \\
7112 & 5 & 4.2 & Failed Furnace & N08.01 & E27.97 \\
7113 & 5 & 4.2 & Furnace Shell & N08.01 & E27.97 \\
7853 & 6 & 37.3 & HEPA Filter & N06.14 & E26.74 \\
& & & & & \\
\hline
\end{tabular}

Table 4-2. Estimated Inventories of Waste Containers Stored on TRU Pads 2-6 Which Will Not be Retrieved

\begin{tabular}{|lllll|}
\hline & $\begin{array}{l}\text { Pu-238 } \\
\text { (inside } \\
\text { culvert) }\end{array}$ & $\begin{array}{l}\text { Pu-239 } \\
\text { (inside } \\
\text { culvert) }\end{array}$ & $\begin{array}{l}\text { Pu-238 } \\
\text { (outside } \\
\text { culvert) }\end{array}$ & $\begin{array}{l}\text { Pu-239 } \\
\text { (outside } \\
\text { culvert) }\end{array}$ \\
\hline \hline Mean Value(Ci) & 74 & $* * *$ & 170 & $* * *$ \\
Standard Deviation & 148 & $* * *$ & 284 & $* * *$ \\
$\begin{array}{l}\text { Maximum Value (gr) } \\
\text { Estimated Inventory }\end{array}$ & 370 & 11.4 & $* * *$ & 302 \\
$\begin{array}{l}\text { (Ci) } \\
\text { Pad Number }\end{array}$ & 2 & 6 & 740 & $* * *$ \\
Container Type & drum & drum & Misc. & Steel box \\
\hline
\end{tabular}




\subsection{Assumptions in Analysis}

Prior to providing a discussion of the accident analysis, it is important to identify the assumptions that were made concerning retrieval activities, procedures, and the layout of the operations. Any deviations from these assumptions may invalidate this evaluation. The following may be candidates for Operational Safety Requirements (OSRs) or Technical Safety Requirements (TSRs).

- It is assumed that an average of 100 drums will be exposed at any one time during the retrieval activities. This requires that the total number of drums that are "unearthed," in the purging station and in the staging area does not exceed 100 drums. This assumption does not include the number of drums that will be transported to other pads (or designated area) for storage.

- Frequency calculations were based on an assumption that 2,000 drums will be retrieved per year. If it is anticipated that more than 2,000 drums will be retrieved per year, the frequency calculations must be reviewed to determine the impact to the analysis.

- It is assumed that the maximum TRU inventory for pad drums on pads 2-6 is 20 curies.

- It is assumed that prior to any retrieval activities, temporary barriers will be strategically placed to protect the TRU pads from potential vehicle accidents involving non-retrieval vehicles.

- It is assumed that each drum will be visibly inspected on all available surfaces to identify areas of severe corrosion or signs of bulging. Drums for which these conditions are met will be handled using special precautions to reduce the risk of a potential release.

- Drums and equipment will be grounded prior to equipment to drum contact.

- For each drilling operation it is assumed that the drill bit will be examined for wear and replaced as necessary to avoid breaking worn bits.

- It is assumed that no more than 100 culverts, casks, steel boxes, etc., will be moved per year in order to gain access to the drums being retrieved.

- It is assumed that culverts, casks, steel boxes, etc., will be moved a minimal distance $(<$ $100 \mathrm{ft}$.) to the next available pad space and that the maximum lifting height during movement is 3 feet.

Other assumptions are listed in Sections 2.0 and 3.0, regarding the design and process, and throughout section 6.0 regarding release scenarios. 


\subsection{Retrieval Drum Accident Analysis}

This section provides a description of the accidents considered for the safety evaluation of the retrieval activities. Only accidents that are unique to the retrieval activities are considered. As a minimum the accidents considered in the existing authcrization basis (du Pont 1986) were considered for retrieval activities to provide a comparison of the incremental risk involved in retrieving the waste drums. For retrieval activities involving pad drums the following scenarios were considered: drum rupture-externally induced, vehicle collision, fire, deflagration due to retrieval activities, and deflagration due to vent and purge activities. Because of the numerous parameters that contributed to the frequency calculation for the deflagration scenario during retrieval activities, an uncertainty analysis was provided. The incremental risks during retrieval activities due to earthquakes and tornadoes were considered insignificant as described in subsections 6.1 and 6.2 .

\section{AIRBORNE RELEASE FRACTIONS}

Radiological dose calculations were based on airborne concentrations of Pu-238. The amount of airborne $\mathrm{Pu}-238$ was computed by multiplying the inventory involved in the postulated scenario by the damage ratio and an airborne release fraction. The damage ratio represents the fraction of material (or inventory) impacted by the accident-generated conditions. The airborne release fractions are based on the inherent physical, chemical, and radiochemical characteristics associate: . with the radionuclide and represent the amount of material that can be suspended in air ain available for transport. The bases for the airborne release fractions used for the accident analyses described in this report are provided below:

Accidents involving fires: An airborne release fraction of 5E-4 was applied to the amount of material available for release in a fire scenario. Studies performed on burning of uraniumcontaminated wastes (Mishima and Schwendiman, 1973) indicate that the release fraction ranged from .05 to .003 percent for a fire in an open drum. The recommended bounding and median airborne release fractions for burning packaged mixed waste are $5 \mathrm{E}-4$ and $8 \mathrm{E}-5$, respectively (U. S. DOE, 1993b). More conservative airborne release fractions are given for uncontained cellulosics and uncontained plastics (U. S. DOE, 1993b), however these fractions were not considered applicable for this situation based on the containment structure of the waste in the drums and experience at SRS. SRS burning of liquid, contaminated solvent in large open pans indicated that more than $99.9 \%$ of the principal activity (Ru-106) remained in the residue (du Pont 1988). Since ruthenium is more volatile than plutonium, the use of an airborne release fraction of $5 \mathrm{E}-4$ is substantiated through this experience.

Accidents involving deflagration; An airborne release fraction of 1E-3 was applied to the amount of material available for release in a drum deflagration scenario. This value is the bounding airborne release fraction due to shock and blast effects for materials on which surface contamination may be found, such as combustible solids including paper, rags, cardboard, plastic, wood, and wall board. Although a deflagration in a drum could result in a subsequent fire in the drum, an airborne release fraction of $1 \mathrm{E}-3$ is more conservative than the airborne release fraction for a fire.

All other accidents: An airborne release fraction of 5E-4 was applied to the amount of material available for release due to all other accident scenarios (i.e. other than fires and deflagrations). Airborne release fraction due to punctures, falls, and vehicle impacts were not available in the literature reviewed. Based on the low energies involved in puncturing or dropping of a drum as compared to the energy involved in a fire and release fractions used for similar type of analyses at Hanford (WHC 1992), an airborne release fraction of 5E-4 is considered bounding. 


\section{ATMOSPHERIC MODELING}

Radiological doses to the maximally exposed offsite individual and co-located worker were calculated using the AXAIR89Q computer code (Hamby and Huang, 1991) which has been formally verified using Westinghouse Savannah River Company procedures (Hamby 1990). Doses to the co-located worker were calculated at a distance of 640 meters (WSRC 1993b) using $50 \%$ meteorology. Doses to the offsite individual were calculated at the closest site boundary using worst case $(99.5 \%)$ meteorology. Table 6-1 provides a summary of the frequencies, consequences, and risks calculated for each of the postulated accidents.

\subsection{Earthquake}

Within the SWDF, radioactive and hazardous waste are stored in various types of containers. The authorization basis for the SWDF (du Pont 1986) considered a release from the solvent tanks to the groundwater to be the most significant risk due to an earthquake. Drum rupture due to an earthquake was considered an unlikely event in the authorization basis and was not analyzed. The authorization basis considered ruptures from container handling to be a much more likely event. The incremental risk due to retrieval activities would only be considered during the time that the soil was removed from the drums and prior to overpacking. Since corrosion of the earth-covered drums is uncertain, the structural integrity of the uncovered drums may not be as sound as other drums stored within the SWDF that are not covered. Once the drums have been overpacked or are inspected and determined to be sound, there is no additional risk due to an earthquake in the SWDF.

Presently there are approximately 19,000 drums stored on TRU pads 2-21 in the SWDF. Approximately $47 \%$ of the drums are stored on the earth-covered mounded pads 2-6 (the mounded pads being excavated). At any one time during the retrieval activities no more that 100 drums will be uncovered prior to overpacking. The amount of uncovered drums involved in the retrieval process comprises approximately $1 \%$ of the pad drums on all other TRU pads (TRU pads that are not mounded with soil) in the SWDF. The earthquake-related incremental risk of the retrieval activities is considered insignificant based on all other waste containers and waste inventories stored at the SWDF.

\subsection{Tornadoes}

As discussed in the earthquake scenario, the maximum number of uncovered drums during the retrieval process represents approximately $1 \%$ of the total number of pad drums on all other TRU pads in the SWDF. For this evaluation, the incremental risk of exposing a maximum of 100 additional drums for consideration in the tornado analysis is inconsequential.

\subsection{Drum Rupture - Externally Induced}

During the TRU retrieval activities, there will be several opportunities for rupturing a drum. Drum rupture could occur from a puncture by the excavating equipment or from the forklift, from a missile generated by a high wind, or a breach that occurs due to a drum fall. Frequency and consequence analysis for drum ruptures and punctures are provided in the following sections.

\subsubsection{Frequency}

A drum puncture could occur during excavation of the TRU pad from a front-end loader, the telescopic excavator, or the electro-mechanical manipulator arm or during drum handling, by the 
forklift. Frequencies for these events were considered in the fault tree analysis for a drum deflagration. The basis for the frequencies as well as the fault tree are provided in Appendix A. The cumulative frequency for a puncture of a drum during excavation of the mounded pad or during drum movement is $7.7 \mathrm{E}-1 /$ year.

There is a potential for a drum to fall from a height of approximately 4 feet due to a forklift drop. The frequency for this event is identified in the fault tree analysis for a drum deflagration, and the basis for the frequency is provided in Appendix A. The frequency for a forklift drop is $2.0 \mathrm{E}-$ 1 year based on two movements per drum (5.0E-5 forklift drops per movement $\times 4,000$ drum movements).

A 4-foot drop however, does not guarantee that the drum will breach. When new, the drums used to store TRU waste (DOT 17C specified drums) are required to withstand a 4-foot drop on their weakest point when filled with water to $98 \%$ capacity. Drop tests conducted at Sandia National Laboratories (SNL) indicate that these drums can withstand drops of up to 120 feet without failure. In the Sandia study, 17 full scale drums were dropped from heights ranging from 21 to 120 feet with weights ranging from 60 to over $700 \mathrm{lbs}$. During these tests, lids of four drums failed (came off), with only one breach of the inner liner resulting in minimal loss of contents. No breaches of the drum walls or bottoms were observed. During crushing tests of drums containing various waste types, lid separation occurred in 8 out of 12 tests; however, no contents of the drums were lost due to the rigid liner and the polyethylene bags surrounding the waste (Huerta, et al. 1983).

The waste drums on pads 2-6 are estimated to weigh, on average, approximately $200 \mathrm{lbs}$. If new, these drums would not be expected to breach if dropped from a 4-foot height. Due to the potential for corrosion, however, some of the drums may be weakened and may not be able to withstand a 4-foot drop. Prior to movement/lifting, it is assumed that each drum will be visibly inspected on all available surfaces to identify areas of severe corrosion. If severe corrosion exists, it is assumed that the lifting device will be modified to reduce the potential for dropping the drum or to contain any loose material that may spill out. Based on these operational assumptions and previous estimates of corrosion, it is assumed that $20 \%$ of dropped drums will breach. Thus, the frequency of a drum rupture due to a dropped drum is (2.0E-1 drops/year x 0.2 ruptures/drop) $4.0 \mathrm{E}-2$ ruptures per year.

Based on process knowledge, there is suspicion that drums on TRU pad 2 do not have liners. On TRU pad 2, 386 pad drums are contained in 83-gallon overpacks (Barber, Stumbaugh 1992). These drums were placed in overpacks because they were not galvanized. It is believed that the ungalvanized drums were not equipped with liners. The frequency, therefore, of drum ruptures due to forklift drops may be increased for a short duration of the project, during the retrieval activities for TRU pad 2. For conservatism, it is assumed that $100 \%$ of the unlined drums will breach if dropped. The frequency of drum rupture during the retrieval of the unlined drums is (5.0E-5 forklift drops per movement $\times 800$ drum movements) $4.0 \mathrm{E}-2$ ruptures per year. Since the process rate for retrieval activities is 2,000 drums per year, there is a remainder of approximately 1,600 drums with liners that will be retrieved during the same year the drums on pad 2 are retrieved. Thus, the total frequency for the year in which the drums on pad 2 are retrieved is 7.2E-2 ruptures per year (5.0E-5 forklift drops per movement $\times 3,200$ movements of lined drums x 0.2 ruptures per drop $+4.0 \mathrm{E}-2$ ruptures of unlined drums per year).

\subsubsection{Consequences}

Although the drums on pads 2-6 are significantly older than the drums tested at SNL, it is unlikely that any contents in the drums will be lost due to puncture or a breach caused by a 4-ft drop. It is expected that the liner and waste bags would provide some additional containment. The authorization basis for the SWDF assumes that only $1 \%$ of the material in a drum is available for release due to a puncture or container breach. Based on the Sandia studies, the additional 
containment provided by the liner and plastic bags, and the assumptions in the authorization basis for the SWDF (du Pont 1986), the damage ratio for a drum puncture or breach due to a 4-ft drop is conservatively assumed to be $10 \%$. Therefore, the number of curies of $\mathrm{Pu}-238$ that would be available for release is 2 curies.

The damage ratio for the unlined drums is also considered to be $10 \%$. Since the unlined drums have been placed in overpacks this damage ratio is comparative to the damage ratio used in the WHC safety analysis for a 30 meter drum drop of drums with liners.

To account for the amount of material that would become respirable during the release, an airborne release fraction of 5E-4 is applied to the amount of material available for release. Table 6-1 gives the resultant consequences to the maximally exposed offsite individual and the co-located worker.

\subsection{Equipment/Vehicle Collision}

\subsubsection{Frequency}

Several drums could be ruptured due to an equipment or vehicle collision with waste drums that have been uncovered. The accident rate for motor carriers on open highways is $2.5 \mathrm{E}-6$ per vehicle-mile (U. S. DOC, 1990). Since the speed of the vehicles traveling near the waste drums on the TRU pads is less than 1/3 of the speeds that can be expected on open highways, this accident rate is expected to be much lower for traffic in the SWDF. The accident rate was multiplied by $1 / 9$ to account for the lower speeds in near the TRU pads. Reduction of the statistical accident rate takes into consideration that the stopping distance required is reduced by the square of the speed reduction. It is assumed that approximately 6 vehicles (necessary for the retrieval activities) will be traveling approximately $250 \mathrm{miles} / \mathrm{year}$ in the vicinity of the uncovered drums. The frequency for a vehicle accident in the vicinity of an uncovered drum is estimated to be (2.5E- 6 accidents/vehicle mile $\times 1 / 9 \times 6$ vehicles $\times 250$ miles/year) $4 \mathrm{E}-4$ accidents per year. A conditional probability of 0.5 is applied to account for the probability that the vehicle will veer towards the drums during an accident. The resultant estimated frequency is $2 \mathrm{E}-4$ accidents per year.

\subsubsection{Consequences}

Because of the low speeds of the vehicles traveling near the TRU pads, the energy involved in the impact would be low. The consequence analysis involves a vehicle impact which would breach four drums. Since each drum diameter is approximately two feet wide, a breach of four drums is a reasonable estimate for this scenario considering a vehicle width of four to six feet. The basis for the damage ratio to the drums is assumed to be the same as the damage ratio assigned due to an equipment puncture, $10 \%$. The resultant radionuclide quantities available for release would be (4 drums $\times 20 \mathrm{Ci} \times 10 \%$ ) 8 curies of $\mathrm{Pu}-238$. To account for the amount of material that would become transportable during the release, an airborne release fraction of $5 \mathrm{E}-4$ is applied to the amount of material available for release. Table 6-1 gives the resultant consequences to the maximally exposed offsite individual and the co-located worker.

The resultant frequencies and consequences as presented in Table 6-1 are plotted on the graphs in Figures 8-1 and 8-2. From this graphical representation, it is apparent that the number of drums breached by a vehicle collision could be increased by an order of magnitude and still not exceed the risk acceptance criteria. 


\subsection{Fire in a Drum}

For postulated accidents involving a fire, this evaluation will only consider a fire in an open waste drum. It will be assumed, for purposes of this evaluation, that a fire in a drum that is not breached would lead to the ignition of the hydrogen gas mixture and cause a deflagration in the drum. Deflagrations are considered in Section 6.6.

\subsubsection{Frequency}

The SRS Data Banks (Durant, 1992) were searched and no fires on the TRU pads within the Solid Waste Disposal Facility are recorded. There have been fires within the trenches during periods when fill was not placed on the waste until the trench was full (this process has changed since then and soil is placed over open waste trenches each day).

To estimate the frequency of a fire involving an open drum the source with the highest potential for causing a fire was considered to be a vehicle collision. Highway statistics indicate that $2.5 \%$ of all vehicle accidents result in a fire (National Safety Council, 1990). Therefore, the frequency of a vehicle collision with a waste drum is multiplied by $2.5 \%$ to estimate a frequency of $5 \mathrm{E}-6$ fires per year involving an open drum.

\subsubsection{Consequences}

Based on the small amount of fuel that the vehicles traveling next to the TRU pads will be carrying and the low energies involved in the impact, it is assumed that the fire will be extinguished by personnel or burn out itself within 10 minutes and will therefore, not spread beyond 4 drums. The inventory available for release due to a fire is assumed to be 40 curies of $\mathrm{Pu}-238$ (4 drums x 20 curies/drum $\times 50 \%$ damage ratio). An airborne release fraction which is accepted for burning $\mathrm{Pu}$ waste of 5E-4 (Mishima and Schwendiman, 1973 and U. S. DOE, 1993b) is conservatively applied to the amount of material released due to a fire of an open drum. Table 6-1 gives the resultant consequences to the maximally exposed offsite individual and the co-located worker.

\subsection{Deflagration of a Drum}

Radiolysis of organic materials produces hydrogen, carbon dioxide, carbon monoxide, and light hydrocarbon gases. Waste which is stored in the drums on TRU pads 2-6 was disposed in polyethylene bags. Several bags may be placed inside a drum which is lined with a 90 mil polyethylene liner. Radiolysis causes bag degradation, which can produce enough hydrogen to exceed the Lower Flammability Limit (LFL) of a gas-air mixture in the bags or liner (U. S. DOE 1993).

Based on the assumed curie loading (20 curies of $\mathrm{Pu}-238$ ) of the drums generated in HB-Line (Fields, 1993) and potentially from other generators of Pu-238 waste, it has been conservatively estimated that a flammable mixture of hydrogen could exist in $28 \%$ of the pad drums located on pads $2-6$, since these drums are not vented. An approximate $12 \% \mathrm{v} / \mathrm{v}$ hydrogen concentration could reside in an unvented drum containing 20 curies of $\mathrm{Pu}-238$ (Davis 1993). This concentration is above the LFL of hydrogen ( $4 \% \mathrm{v} / \mathrm{v})$, but below the lower explosive limit, commonly accepted at $18 \% \mathrm{v} / \mathrm{v}$ (Sherman 1984). Mixing tests conducted for a hydrogen gas mixture (from 5\% to $25 \%$ $\mathrm{v} / \mathrm{v}$ ) in drums containing no waste indicated that after 50 minutes the hydrogen became well-mixed (Dykes 1991). Since the waste will have been stored in the drums for approximately 20 years, it is assumed that a homogenous hydrogen-air mixture exists throughout the waste bags and the void space in the drum. 
An ignition of the flammable mixture of gas containing $12 \%$ of hydrogen would result in a deflagration of the drum. A deflagration at this concentration of hydrogen could be expected to create pressures of up to approximately $60 \mathrm{psig}$ (Thomas 1993). The frequency analysis for deflagrations in TRU waste drums considers ignition sources of the hydrogen mixture during the retrieval actions and the vent and purge systems separately since the consequences during the vent and purge process are more easily mitigated.

\subsubsection{Frequency During Retrieval Activities}

A fault tree analysis was performed to estimate the frequency of a drum deflagration during the drum retrieval activities. In order for a deflagration to occur, three conditions must be met: there must be a sufficient hydrogen mixture in the drum, there must be sufficient oxygen present, and ignition of the mixture must occur. Since oxygen was present in the drums during the initial placement of waste, it is assumed that oxygen is present in the drums. It is assumed that the probability that a flammable concentration of hydrogen could build up is $2.8 \mathrm{E}-1$. This probability was derived by using the percentage of drums which contain Pu-238 as identified in COBRA. The hydrogen could escape, however, if corrosion of the drums has caused through-wall pitting. A probability of 0.2 was assigned to the account for through-wall pitting that is capable of releasing hydrogen.

An ignition source frequency of the hydrogen mixture in the waste drum was considered for three stages of the retrieval process: soil removal, drum movement, and while the drum is uncovered, but stationary. Ignition sources that were considered during these three stages include a spark due to friction between metal waste potentially stored in the drums, a spark resulting from the puncturing of equipment, and autoignition of the gas mixture. Ignition due to a static charge was not considered since it is assumed that the drums and equipment will be grounded prior to contact. The fault tree analysis and a description of the basic events are provided in Appendix A. An uncertainty analysis was also performed, assigning distributions to each of the basic events. After 5,000 iterations of the frequency calculation, the uncertainty analysis provides a distribution of the frequency for a drum deflagration. Results from the fault tree and uncertainty analyses indicate that the $95 \%$ upper bound on the frequency is 3.3E-1 deflagrations per year during retrieval activities. The mean value for this occurrence is $9.6 \mathrm{E}-2$ deflagrations per year. Appendix B of this document provides details of the uncertainty analysis.

\subsubsection{Consequence During Retrieval Activities}

A deflagration of a waste drum containing $12 \%$ hydrogen could result in a maximum pressure inside the drum of approximately $60 \mathrm{psig}$, achieved within 20 to 50 milliseconds. Drum performance based on these pressures, however, is uncertain. According to the DOT design criteria for Type $17 \mathrm{C}$ drums, the drums must be capable of withstanding a hydrostatic pressure test of up to 20 psi (49 CFR 178.115-12). This suggests that the drums could withstand up to 2 to 3 times the tested value. Several studies have been performed on drum performance after the ignition of a flammable mixture of hydrogen in a drum. In the most recent drum explosion tests performed at SRS, 18 drums were filled with hydrogen concentrations ranging from $12 \%$ to $25 \% \mathrm{v} / \mathrm{v}$. During many of the tests, the drums just bulged; in some, the lid was blown off. The lowest hydrogen concentration for which a lid was blown off was at 17\% hydrogen (Dykes 1991). Earlier tests performed at SRS included igniting drums with various hydrogen contents as well as simulated waste material. The results illustrated that with $30-33 \% \mathrm{v} / \mathrm{v}$ hydrogen and 0 to 6 bags of waste in the drums, the lids were blown off in all cases; with 8 to 12 bags of waste in the drums the lids remained in place. The results of tests with $15-17 \%$ hydrogen $\mathrm{v} / \mathrm{v}$ were not as sharply defined. In some instances the lids blew. A 5\% hydrogen mixture in this test failed to ignite (du 
Pont 1986). Studies performed for Idaho National Engineering Laboratory (INEL) drums resulted in the following conclusions (WHC 1992):

- During explosion tests for $14 \%$ hydrogen and $62 \%$ oxygen, the drums did not rupture, but bulging of the drums occurred.

- At $30 \%$ hydrogen and $15 \%$ oxygen, the drums always ruptured, blowing the lid off, with no rupture to the side of the drums.

- A maximum of $41 \%$ of the contents was released when the drums ruptured. This was usually accompanied with burning of the simulated waste.

For purposes of this analysis, it will be conservatively assumed that all deflagrations in a waste drum will cause the lid to blow off of the drum, and the damage ratio to the material in the drums would be $50 \%$. Using the inventory assumptions described in Section 4.0, 10 curies of Pu-238 would be available for release. An airborne release fraction, which is accepted to be bounding for explosive releases, of $1 \mathrm{E}-3$ is applied to the amount of material available for release due to a drum deflagration (U.S. DOE, 1993b). Table 6-1 gives the resultant consequences to the maximally exposed offsite individual and the co-located worker.

During a drum test at SRS, the velocity of a lid, after an ignition of a $15 \%$ to $30 \%$ hydrogen mixture, was observed to be approximately $109 \mathrm{ft} / \mathrm{sec}$ during the first few feet of travel (du Pont 1986). Based on some conservative estimates, there is a potential for a drum lid to penetrate a another drum and, thus, cause a subsequent deflagration. The frequency for this subsequent deflagration has been conservatively calculated to be $1.5 \mathrm{E}-4$ per year (see Appendix $\mathrm{C}$ for derivation of this frequency). For this scenario, the damage ratio would be doubled (since two drums would deflagrate) and 20 curies of $\mathrm{Pu}-238$ would be available for release. The same airborne release fractions described in the previous paragraph apply.

\subsection{Deflagration in a Drum During Vent and Purge Activities}

\subsubsection{Frequency}

Hydrogen in air is flammable over the range from $4 \%$ to $75 \%$ hydrogen and the stoichiometric value is $29.5 \%$ hydrogen. The minimum ignition energy of a stoichiometric hydrogen-air mixture is $0.02 \mathrm{~mJ}$, and the autoignition temperature is $500^{\circ} \mathrm{C}$ (minimum). For concentrations which could be expected for the drums to be retreived (12\% hydrogen) the minimum ignition energy is approximately 5 times higher, $0.1 \mathrm{~mJ}$ (Lewis and Elbe, 1987). Explosion testing was conducted for a similar container vent system that is proposed for use at the Hanford Site. Forty-two tests using worn bits, standard steel bits, and carbide tipped steel bits were conducted for chambers that were filled with a gas mixture with hydrogen concentrations at approximately $30 \% \mathrm{v} / \mathrm{v}$. In these tests, the chamber was constantly monitored for temperature and pressure increases. In none of the 42 tests was the stoichiometric hydrogen-air mixture ignited. During one of the tests, a standard steel bit broke before it punctured the carbon steel test coupon. After the piece broke off, the drill began to rotate again and frictional sparks were observed, but no ignition occurred. Temperatures measured at the bit contact with the test coupon were significantly less than the minimum autoignition temperature (Cashdollar, et al. 1993).

In the fault tree analysis for the drum deflagration during retrieval activities, it was assumed that $28 \%$ of the drums had a Pu-238 inventory capable of generating an ignitable concentration of hydrogen through radiolysis of the plastics; $80 \%$ of those drums were assumed to be hydrogen tight. Ignition of a flammable mixture in the drum or in the vacuum chamber surrounding the drill 
tight. Ignition of a flammable mixture in the drum or in the vacuum chamber surrounding the drill bit is possible. The ignition sources available during the vent and purge activities include a spark from the drilling equipment, friction from the drill bit contact with the drum lid, and static electricity. It is assumed that the drum, drill, and purge equipment will be grounded prior to contact with each other. It is further assumed that the drill and purge equipment will be non sparking equipment as specified for the applicable hazard class and division according to the National Electrical Code (Bodurtha 1980). For each drilling operation it is assumed that the drill bit will be examined for wear and replaced as necessary to avoid breaking worn bits.

Based on the experimental data resulting from the explosion testing of the drum venting operation as previously discussed, the probability of ignition due to the drilling is calculated by employing the methodology used by SRS to determine failure rates (Blanton and Eide, 1993) as follows :

$$
\begin{aligned}
& \text { Where } \mathrm{Mn}=\text { Mean probability } \\
& M n=\frac{(2 n+1)}{(2 D+2)}=\frac{1}{(2(42)+2)} \approx 1 E-2 \quad \begin{array}{ll}
n & =\text { Number of Failures (0 for tests) }
\end{array}
\end{aligned}
$$

Since the explosion testing was conducted using much higher concentrations of hydrogen in air then will be present in the TRU waste drums to be retreived, this calculation of mean probability is considered to be too conservative. Based on the lower concentrations of hydrogen, the precautionary measures described in the preceeding paragraph, and the fact that the drill motor will be operated remotely, the probability of igniting the gas mixture inside of the drum during vent an purge activities is estimated to be no greater $1 \mathrm{E}-3$. The frequency is therefore calculated by multiplying the probability by the number of drums containing hydrogen that will be vented and purged in a year, which results in (2,000 drums per year x 1E-3 x 28\% X 80\%) 4.5E-1 drum deflagration per year.

This frequency could be reduced by providing a blanket of nitrogen around the drill bit upon contact rather than extracting the potentially flammable gas mixture into the chamber around the drill. The nitrogen should be supplied at a rate to dilute any hydrogen escaping from the drum by a factor of 4 to 1 ( 4 parts nitrogen to 1 part hydrogen). At this concentration the only flammable gas mixture would be inside the drum itself and the potential for ignition would be reduced to that of an electric spark inside the drum.

\subsubsection{Consequences}

The damage ratio to the contents of the drum due to a deflagration inside the explosion proof vessel is would be the same as that for the deflagration scenario described above; $50 \%$ resulting in 10 curies of Pu- 238 being available for release. An airborne release fraction, which is accepted to be bounding for explosive releases, of $1 \mathrm{E}-3$ is applied to the amount of material available for release due to a drum deflagration (U.S. DOE, 1993b). Table 6-1 gives the resultant consequences to the maximally exposed offsite individual and the co-located worker.

\subsection{Deflagration Due to Flammable Mixture of Solvents in the Drums}

The deflagration scenarios described in Sections 6.6 and 6.7 of this report were based on the accumulation of hydrogen due to the radiolysis of the polyethylene assuming a $20 \mathrm{Ci}$ inventory of $\mathrm{Pu}-238$. Although the assumed $\mathrm{Pu}-238$ inventory (20 Ci per drum) is extremely conservative, there is some basis for this bounding assumption as described in Section 4 of this report. The inventory of chemicals in the drums is not documented in a database such as the COBRA database, which documents the inventories of the radionuclides. Based on process knowledge, there is a high potential for the drums to contain solvent laden rags, however, the quantity and 
concentration of the solvent in each drums is uncertain. It is possible that the concentration of the solvents in some of the drums could be such that a flammable mixture of solvent and air is present in the head space of the drums. To quantify this probability, however, is impossible due to the lack of chemical waste inventory records for the drums on TRU pads 2-6.

As reported in Thomas 1994, ignition of a flammable mixture of solvents (hydrocarbons) and air requires more energy than a flammable mixture of hydrogen and air. Analyses of deflagrations due to potential flammable mixtures of hydrogen and air has already been considerea for the drums which contain Pu-238 (28\%) of the drums. Analyses of a deflagration due to potential flammable mixtures of hydrocarbons and air need only be considered for the non-Pu-238 bearing drums $(72 \%)$. From a consequence standpoint, the deflagration scenario involving $\mathrm{Pu}-238$ drums bounds the deflagration consequences of a non- $\mathrm{Pu}-238$ bearing drum, since the non- $\mathrm{Pu}-238$ bearing drums contain considerably less activity than the assumed inventory of the Pu- 238 bearing drums. To maximize the frequency estimate for a deflagration of a non- $\mathrm{Pu}-238$ bearing drum, it can be conservatively estimated that $100 \%$ of the drums contain sufficient concentrations of solvent to produce a flammable gas mixture. Assuming that the probability for ignition of a flammable solvent gas mixture is the same as the hydrogen gas mixture, the frequency of deflagration of a non-Pu-238 bearing drum could be as much as 2.6 times the frequency of a Pu- 238 bearing drum $(72 \% / 28 \%)$. This estimate is considered to be conservative, although it is anticipated that a more realistic estimate would fall into the frequency range considered for normal operations, 0.1 to 1 events per year, as defined in DOE's proposed Standard (U. S. DOE 1994).

Since adequate data is unavailable to quantify the frequency of a deflagration of a non-Pu-238 bearing drum, a qualitative comparison to the previously discussed deflagration scenarios is made. As stated in the previous paragraph, the consequences of a non-Pu-238 drum deflagration would be considerably higher than those for a deflagration of a non Pu-238 drum. As depicted on Figure 8-1 of this report, the consequences of a deflagration of a Pu-238 bearing drum are very close to the lowest consequence of the WSRC $9 \mathrm{Q}$ risk acceptance curve and more than an order of magnitude lower than the lowest consequence identified in the step function as defined in DOE's Proposed Standard (U. S. DOE 1994). The consequences of a non-Pu-238 deflagration are lower than the consequences accepted for normal operating limits. Even though the frequency of a drum deflagration in a non-Pu-238 drum could be higher than the scenarios identified on Figure 8-1, this accident scenario would not exceed the risk acceptance criteria.

\subsection{Bulging and Severely Corroded Drums}

Special handling precautions will be implemented on a case-by-case basis if drums are observed to be bulging due to over pressurization, or are severely corroded to the extent that the structural integrity of the drums could not provide containment of the material inside the drum due to lifting. The number of drums with either condition is expected to be low. The consequences of this condition are, however, bounded by the consequences of the accident scenarios described above.

\subsection{Criticality}

Under ideal conditions (i.e. ideal geometry and moderation), the minimum mass of Pu-239 required for criticality is 450 grams (ANS 1983). Based on the waste acceptance criteria, criticality is not a concern with the drums stored on pads 2-6. An infinite array of 55 gallon drums stacked two high with up to 200 grams of Pu-239 is considered safe from a criticality standpoint (Reilly, 1982).

\subsection{Storage of Retrieved Vented Drums}

During retrieval activities, retrieved drums that have been vented, purged, and equipped with a filter will be placed in a staging area within the TRU Retrieval weather cover and transported to 
TRU waste pads after a number of drums (fewer than 100 drums) have been accumulated. These drums will be placed directly on the pads (i.e. not in culverts). Although the source term used in the analysis of TRU Retrieval activities considered a bounding inventory of $20 \mathrm{Ci}$ of Pu-238 per drum, this assumption was intended only to add a margin of safety to the analysis and was not intended to imply that the drums are outside of the operating limits imposed on direct pad storage.

The risk due to placement and storage of these drums onto existing TRU waste pads (other than pads 2-6) is considered to be bounded by the analysis of the TRU Retrieval activities as provided in this report. This statement is justified by the fact that the retrieved and vented drums will be in a safer configuration, as the drums will be free of any potential flammable mixtures of gas and the drums will be handled by routine equipment.

The number of drums transported to an existing TRU waste pad will exceed the assumption listed in Section 5, which states that an average of only 100 drums will be exposed at any one time during retrieval activities. The assumption of only 100 drums being exposed, however, is only applicable to the number of drums exposed at the pad being excavated. The only accidents associated with TRU Retrieval where the 100 drum assumption was credited are those involving natural hazards (i.e. earthquakes and tornadoes). Risks associated with tornado and earthquake impacts on the storage of $20 \mathrm{Ci}$ (Pu-238) pad drums, including normal pad storage of retrieved drums, are addressed in Kelly, 1993, which does not rely on this 100 drum assumption. 
Table 6-1. Consequence and Risk Summary for Postulated Events

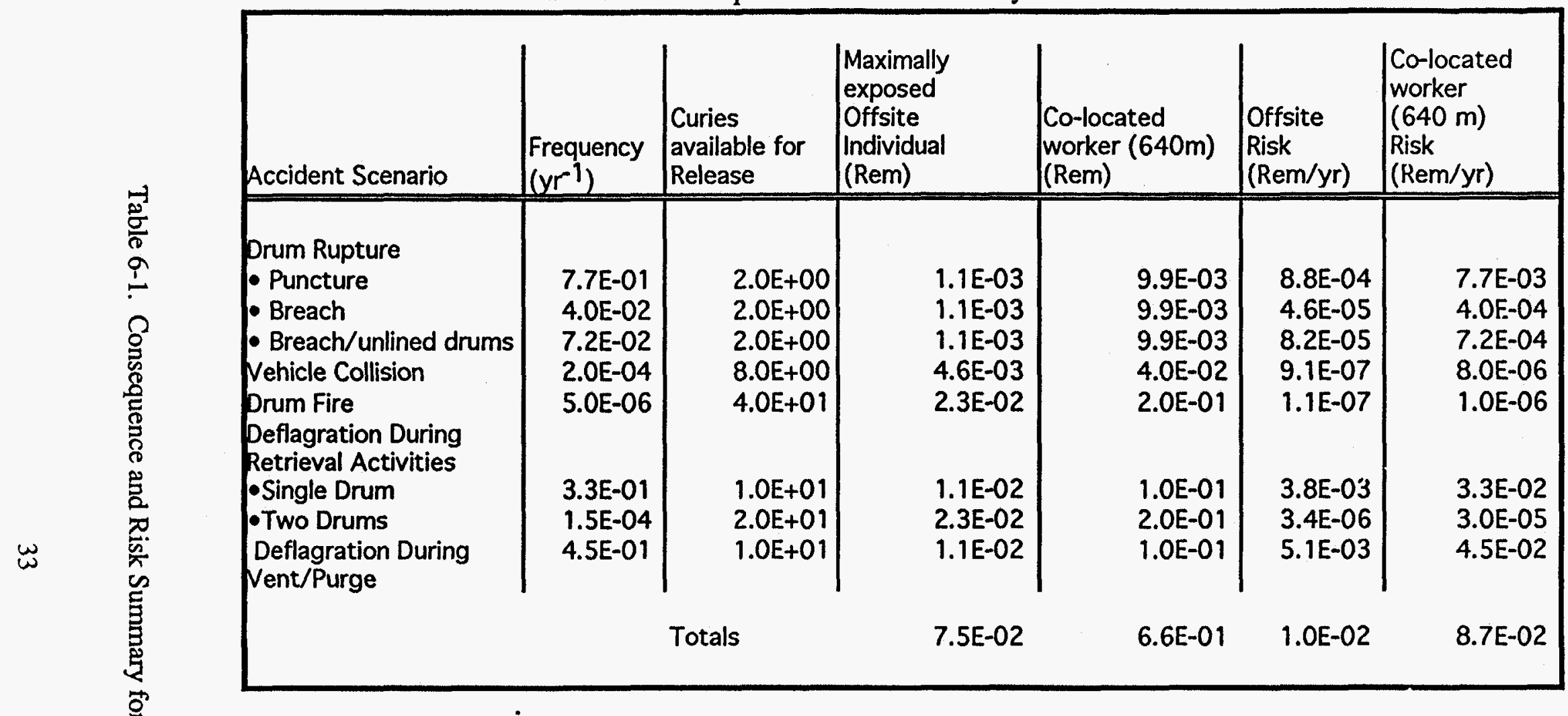

Note: Doses Are calculated by multiplying the curies available for release by the airborne release fraction (1E-3 for deflagrations and 5E-4 for all others) and by the dose/curie fraction given by AXAIR89Q.

Doses to the maximally exposed offsite individual are based on $99.5 \%$ meteorological data, while doses to the co-located worker are based on $50 \%$ meteorological data 


\subsection{Accident Analysis for Other Containers}

During retrieval activities, it may be necessary to move other waste containers such as culverts, steel boxes, concrete casks, etc., to gain access to the drums to be retrieved. This section provides a safety evaluation of the movement of such containers. The word containers, when used in this section, refers to waste containers stored on TRU pads 2-6 other than the drums winich are to be retrieved.

Radiological dose calculations were based on the same methodology described in Section 6.0 of this evaluation. Accident scenarios discussed in this section include those that are specific to the movement of the containers that may be necessary to gain access to the drums being retrieved. It is assumed that only containers that have been visually inspected and are judged to be of sound structural integrity will be moved using standard lifting procedures.

\subsection{Container Breach}

There is a potential for the containers to be dropped during movement. The majority of the container movements will be performed with a forklift unless a crane is preferred. For most containers, the lifting force will be applied to the structural members on the container bottom to prevent puncturing the container shell. To the concrete structures, a force may be applied near the top of the container to tip the container enough to place blocks underneath to allow the forks to be placed beneath the container; lifting eyes may be attached to the steel containers if a forklift cannot be used (Wilson 1993). In all cases, it is assumed that the containers will be lifted no higher than 3 feet.

A 3-foot drop would not be expected to breach a culvert or the drums within such as to cause a release. The culvert could be overturned, however, in which case the culvert lid would probably come off and expose the waste drums inside.

The SRTC casks are made of reinforced concrete in which an engineered carbon steel box is encased. Other concrete boxes are made of 6" reinforced concrete. Usually, waste that was placed in the large boxes was first wrapped in several layers of plastic and then placed in wooden crates. Because of the structural integrity of the steel boxes and concrete containers, the culvert is most vulnerable to a breach due to a fall and was, therefore, considered in the analysis as the most bounding scenario.

\subsubsection{Frequency}

Based on a search through the waste management data bank, the probability of a crane/forklift drop was estimated to be $1 \mathrm{E}-3$. A drop of a concrete culvert would not necessarily result in a release unless the culvert were overturned, the culvert lid fell off, and the drums inside were breached. To estimate the frequency for a culvert to overturn and breach the drums inside, it will be assumed that $50 \%$ of all culvert drops will result in overturning and disengagement of the lid. It will be further assumed that $75 \%$ of all container movements will involve culverts. Assuming that only 100 containers are moved per year during the retrieval process, the resultant frequency of overturning a culvert is estimated to be 4E-2 per year.

\subsubsection{Consequence}

Based on the Sandia study for drum drops referenced in Section 6.3.1 of this evaluation, the damage ratio from a drop of a drum (or overturn) is expected to be low, especially at low heights. In addition, the concrete culvert will provide considerable containment of the drums if the drums are damaged in the culvert overturn. Based on the drum arrangement in the culverts, it is more 
likely for the material in the top drums in a culvert to be released due to a culvert overturn. In the drum rupture scenario described in Section 6.3 , it was assumed that $20 \%$ of drums dropped will breach. Applying this same percentage to the top seven drums in a culvert would result in 1.4 drums being breached. For calculating consequences, this number has been rounded down to 1 drum due to the fact that SRTC has estimated that the corrosion rate inside the culverts will be lower based on the curie loading of drums within culverts (i.e. heat given off by the decay of the radioisotopes will provide a drying effect inside the culvert) (Williams 1991). The damage ratio of the drum that is breached is considered to be $10 \%$. The number of curies of Pu-238 that would be available for release is approximately 40 curies.

The airborne release fraction of 5E-4 is considered bounding for this low energy event as discussed in Section 6.3.2 of this report. Table 7-1 gives the resultant consequences to the maximally exposed offsite individual and the co-located worker.

\subsubsection{Summary of Container Breach Scenario}

The conclusions of the analyses are described in Section 8.0. Figures in Section 8.0 graphically compare the risks of each scenario with the WSRC risk acceptance criteria for the offsite and onsite maximally exposed individual. Since the amount of curies released in a scenario is directly proportional to the dose achieved, it can be noted that even using the inventories of the miscellaneous containers (twice the inventory of the culvert scenario) the risk of same accident scenario would fall below the risk acceptance criteria.

\subsection{Vehicle Accident Involving Culverts}

Calculations indicate that a 5,000 lb. truck will not cause damage to a concrete culvert at speeds equal to or less than 25 miles per hour if there is at least one inch spacing between the culvert and the next container. Based on the fact that a weather cover will be placed over the TRU pad during retrieval activities, that only a limited number of vehicles will be operating within a close range of the containers, and that temporary barriers will be placed to protect the TRU pads from accidents involving non-retrieval traffic, an accident involving a vehicle at speeds greater than 25 miles per hour is considered incredible.

\subsection{Fire/Explosion}

Retrieval activities will involve only the movement of the containers stored on TRU pads 2-6 which is necessary to gain access to the drums being retrieved. Since the containers will not be opened, the only increase of risk from fire and explosion would result from an internally induced ignition source.

\subsubsection{Frequency}

Based on the curie loading of the drums inside the culverts and the other containers, there is a potential to generate an explosive mixture of hydrogen due to radiolysis of the plastic wrapping in the container. An internally induced ignition of the explosive mixture could result from friction between the materials in the containers due to movement. The probability, however, of ignition due to the friction between the materials caused by moving the containers is small based on the following:

- Materials in the containers are wrapped in several layers of plastic and may also have been placed in wooden crates before placement into the containers. 
- Movements per container will be minimal. The containers will only be moved once to a nearby location. No other handling of the containers will be necessary.

- The nature of the waste in the containers would limit shifting of the material due to container movement.

- For the steel containers on the TRU pads, the design called for the placement of "string" vents on top of the lid gasket. These string vents are intended to allow for the escape of explosive gases.

Friction of material during routine movement of the large containers is not a likely ignition source. Ignition of the flammable mixture in a drum inside a culvert is the most probable scenario. Friction of material inside a drum that is sufficient to cause ignition of a flammable mixture of gas is most likely to occur if the culvert is dropped. The probability that a culvert is dropped is estimated to be 1E-3. Combined with the probability that friction of the material in one drum will cause the hydrogen mixture to ignite, 1E-2 (using data from the fault tree analysis for a drum deflagration), the resultant probability of ignition of a flammable mixture in a drum due to a culvert drop is $1 \mathrm{E}-5$. To calculate the frequency of ignition the probability is multiplied by the number of culvert movements. It is assumed for this evaluation that $75 \%$ of container movements will involve culverts. Therefore, the frequency is calculated to be (1E-5 x 100 container movements per year $x$ $75 \%$ culverts $x 14$ drums per culvert) approximately $1 \mathrm{E}-2$ per year.

\subsubsection{Consequence}

A deflagration could occur in a drum inside a culvert. Previously, it was estimated that the damage ratio of a drum deflagration was $50 \%$, however the culvert would provide significant containment of the release. During one explosion test inside of a culvert, an explosive mixture of hydrogen (17\%) and air were ignited. In this test, the lid of the culvert lifted and fell essentially straight back on to the culvert (du Pont 1986). Since one drum represents less than $1 / 15$ the volume of a culvert, the energy released by a drum deflagration would be expected to have less of an effect to the culvert, and therefore, the release would be small. The authorization basis for the SWDF (du Pont 1988) estimates that no release would occur from a drum fire in a culvert. Based on the containment structure of the culvert, the estimated damage ratio of a drum deflagration inside a culvert is estimated to be $10 \%$. This would result in approximately 40 curies of $\mathrm{Pu}-238$ being available for release.

The same release fraction of $1 \mathrm{E}-3$ that was applied to the drum deflagration in Section 6.6 .2 of this evaluation is used for this scenario. Table 7-1 gives the resultant consequences to the maximally exposed offsite individual and the co-located worker.

\subsection{Criticality in Other Containers}

Under ideal conditions (i.e., ideal geometry and moderation), the minimum mass of Pu-239 required for criticality is 450 grams (ANS 1983). Based on the waste acceptance criteria, criticality is not a concern with the drums in culverts stored on pads 2-6. An infinite array of 55 gallon drums stacked two high with up to 200 grams of $\mathrm{Pu}-239$ is considered safe from a criticality standpoint (Reilly, 1982). The maximum Pu-239 inventory of all drums inside culverts on pads 26 is 184 grams. This meets the criticality criteria for safe storage of Pu-239 waste.

The maximum Pu-239 inventory of the other containers on pads $2-6$ is 302 grams. This inventory is below the 450 gram limit referenced above for criticality under ideal conditions. 
Table 7-1. Consequence and Risk Summary for Postulated Events for Culvert Movement

\begin{tabular}{|c|c|c|c|c|c|c|}
\hline Accident Scenario & $\begin{array}{l}\text { Frequency } \\
\left(y r^{-1}\right)\end{array}$ & $\begin{array}{l}\text { Curies } \\
\text { available for } \\
\text { Release }\end{array}$ & \begin{tabular}{|l} 
Maximally \\
exposed \\
Offsite \\
Individual \\
(Rem) \\
\end{tabular} & $\begin{array}{l}\text { Co-located } \\
\text { worker }(640 \mathrm{~m}) \\
(\text { Rem })\end{array}$ & $\begin{array}{l}\text { Offsite } \\
\text { Risk } \\
\text { (Rem/yr) }\end{array}$ & $\begin{array}{l}\text { Co-located } \\
\text { worker } \\
(640 \mathrm{~m}) \\
\text { Risk } \\
(\text { Rem/yr })\end{array}$ \\
\hline \multirow{3}{*}{$\begin{array}{l}\text { Container Breach } \\
\text { Deflagration }\end{array}$} & $4.0 E-02$ & $4.0 E+01$ & $2.3 E-02$ & 2.0E-01 & $9.2 \mathrm{E}-04$ & $8.0 \mathrm{E}-03$ \\
\hline & $1.0 \mathrm{E}-02$ & $4.0 E+02$ & 4.6E-02 & 4.0E-01 & 4.6E-04 & 4.0E-03 \\
\hline & & Totals & $6.9 \mathrm{E}-02$ & $6.0 \mathrm{E}-01$ & $1.4 \mathrm{E}-03$ & $1.2 \mathrm{E}-02$ \\
\hline
\end{tabular}

Note: Doses Are calculated by multiplying the curies available for release by the airborne release fraction (1E-3 for deflagrations and $5 \mathrm{E}-4$ for container breach) and by the dose/curie fraction given by AXAIR89Q. Doses to the maximally exposed offsite individual are based on $99.5 \%$ meteorological data, while doses to the co-located worker are based on $50 \%$ meteorological data. 


\subsection{Conclusion}

This evaluation is intended to provide relative risk information to be used as input into the design of the retrieval activities. For conservatism, maximum frequencies and bounding consequences were estimated to compute risk. No credit was taken for the mitigative features which may be provided by the contamination control hut. This evaluation serves as a bounding estimate of risk and is valid as long as the assumptions stated within this document are incorporated into the design and/or operating procedures. As further design information is developed and more information is available regarding the characteristics of the waste containers, this evaluation can be revised to meet the safety analysis requirements of DOE Orders 4700 and 5480.23.

Accident scenarios analyzed in this evaluation result in a greater risk as presented in the authorization basis for the SWDF (du Pont 1988). The most significant factors contributing to the increase in risk are the inventory assumed for all of the drums which will be involved in the retrieval process and the conservatisms taken in the analyses. Although there was a limit of 0.5 curies of TRU waste for pad drums (drums not in culverts), detection limits of the assay equipment and errors found in the COBRA data base have forced the maximum inventory to be conservatively estimated at 20 curies of TRU waste (assumed to be Pu-238) in each drum.

The risk from each of the postulated accident scenarios is below the risk acceptance criteria curve defined in WSRC Procedural Manual 9Q (Figures 7-1 and 7-2). The WSRC onsite risk acceptance curve is truncated at 1E-1/year, because the accepted dose at this frequency is well below the annual exposure value. The dashed line on Figures 8-1 and 8-2, labeled "New Guide" in the legend, represents radiological evaluation guidelines as presented in the DOE Proposed Standard, Evaluation guidelines for Accident Analysis and Safety Structures, Systems, and Components (DOE 1994). As illustrated in the figures, the risk of each of the postulated accidents is well below the evaluation guidelines. 
Rev. 2.

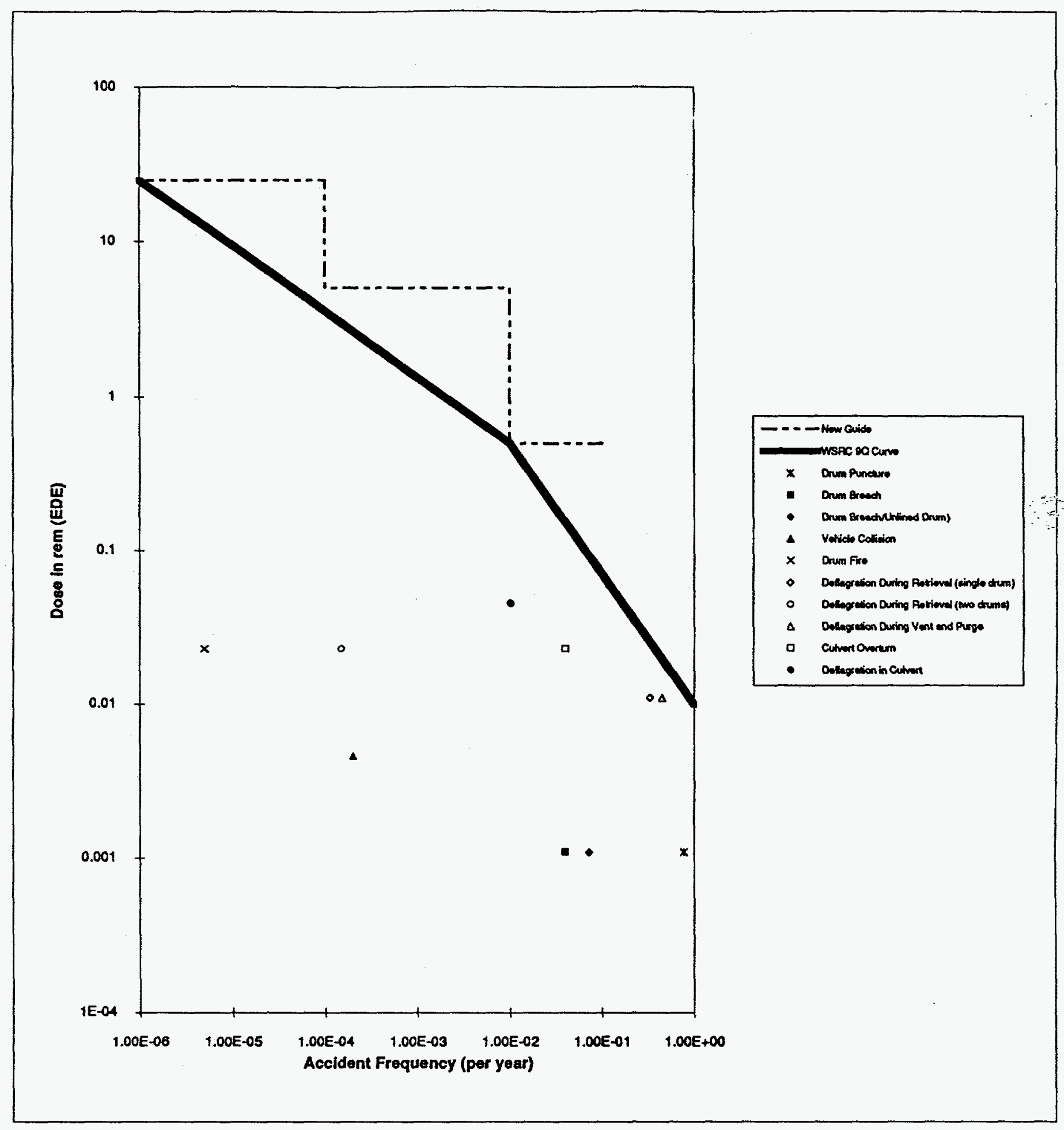

Figure 8-1 Offsite Risk Comparison Criteria 
Rev. 2

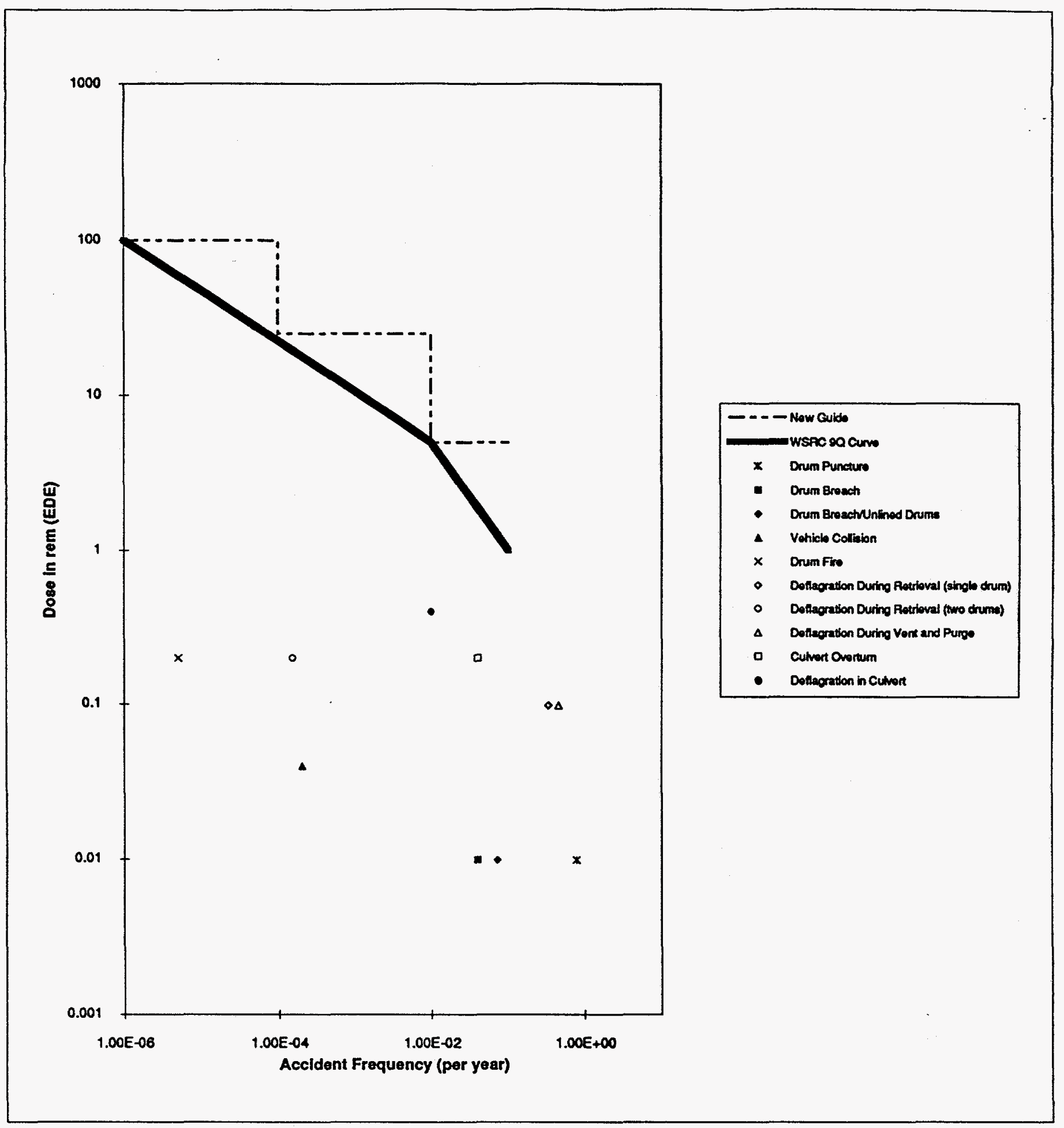

Figure 8-2 Onsite Risk Comparison Criteria 


\subsection{References}

ANS (American Nuclear Society) 1983. "American National Standard for Nuclear Criticality Safety in Operations with Fissionable Materials Outside Reactors," ANSI N16.1-1975, October 7, 1983.

Barber, Amanda S. and Stumbaugh, James E. 1992. "Functional Performance Requirements Phase I (Retrieval) of the Transuranic Waste Facility Project s-2991," NMP-WMP-911261, Westinghouse Savannah River Company, December 15, 1992.

Barradale, E. K. 1993 "Operational Baseline Document for the Retrieval of Transuranic Waste Drums, "WSRC-RP-93-0037 Rev. 1, February 23, 1993.

Benhardt, H. C. et al. 1994. "Savannah River Site Human Error Data Base Development for Nonreactor Nuclear Facilities (U)", WSRC-TR-93-581, Westinghouse Savannah River Company, February 1994.

Blanton, C. H. and Eide, S. A. 1993. "Savannah River Site Generic Data Base Development (U)," WSRC-TR-93-262, Westinghouse Savannah River Company, June 30, 1993.

Bodurtha, Frank T. 1980. "Industrial Explosion Prevention and Protection," Frank T Bodurtha, E. I. du Pont de Nemours \& Company, McGraw-Hill Book Company, 1980.

Cashdollar, Kenneth L., Green, Gregory M. and Thomas, Richard A. 1993. "Explosion Testing for Container Vent System," WHC-EP-0686, Westinghouse Hanford Company, Richland Washington, October 1993.

Chay, S. C. 1990. "Probabilistic Assessment of the Criticality in a Drum or Culvert Containing Suspect FB-Line TRU Waste," STC Report 90-9S21-IWRSR-R1, Westinghouse STC, Pittsburgh Pennsylvania, April 30, 1990.

Davis, Ricardo C. 1993. "Gas Generation Modeling of Unvented TRU Drums (U)," Memorandum to W. M. Bennett, SCS-CMG-930033, August 20, 1993.

du Pont de Nemours \& Co. 1986. "Transuranic (TRU) Waste-Hydrogen Formation-Explosion Tests with Drums and Culverts," Savannah River Plant, E. I. Du Pont de Nemours \& Company letter to S. J. Mentrup, May 1, 1986.

du Pont de Nemours \& Co. 1988. "Safety Analysis - 200 Area Savannah River Plant Burial Ground Operations," DPSTSA-200-10, SUPP 8.

Durant, W. S., et al., 1992. "200-Area Fault Tree Data Bank 1991 Status Report (U)".W. S. Durant, D. F. Baughman, C. S. Townsend, P. Hang, WSRC-TR-92-118, Westinghouse Savannah River Company, March 1992.

Dykes, K. L. and Meyer, M. L. 1991. "Transuranic Drum Hydrogen Explosion Tests (U)", WSRC-TR-90-165, Westinghouse Savannah River Company, Savannah River Site, Aiken, SC, June 1991.

DWG S4-6-189. "Rectangular Concrete Burial Container," E. I. Du Pont De Nemours \& Co., March 23, 1971.

DWG S5-2-10296. "Burial Box for Model "L" Slave Ends," E. I. Du Pont De Nemours \& Co., June 13, 1979. 
Ebra-Lima, O. M. 1991. "Evaluation of Risks Associated with the Retrieval of Buried TRU Waste Drums within the Burial Ground (U)," Memorandum to R. G. Garvin, SRL-NPS-910017, March 27, 1991.

Fields, C. C. 1993. "Technical Guidance for Safety Evaluation Source Term Assumption for TRU Waste Retrieval (U)," WER-SCG-930056, Memorandum from C. C. Fields to S. R. Salaymeh, July 27, 1993.

Hamby, D. M. 1990. "Verification of AXAIR89Q Dose Assessment Code," WSRC-RP-90-1222, Westinghouse Savannah River Company, November 1990.

Hamby, D. M. and Huang, J. C. 1991. "Environmental Dose Assessment Manual (U)," WSRCIM-91-1, Westinghouse Savannah River Company, December 1991.

Huerta, Michael et al., 1983. "Analysis, Scale Modeling, and Full-Scale Tests of Low-Level Nuclear-Waste-Drum Response to Accident Environments," Michael Huerta, Gene H. Lamoreaux, Laverne E. Romesberg, H. Richard Yoshimura, Brain J. Joseph, and Rodney A. May, Sandia National Laboratories, SAND80-2517, TTC-0315, January 1983.

Kelly, J. L. 1993. "Aisle Spacing of Transuranic Waste Drums (U)," WSRC-RP-93-1340, Westinghouse Savannah River Company, November 12, 1993.

Lewis, Bernard and Elbe, Guenther von, 1987. "Combustion, Flames and Explosions of Gases," Third Edition, Academic Press Inc.

Mishima, J. and Schwendiman, L. C. 1973. "Fractional Airborne Release of Uranium (Representing Plutonium) During the Burning of Contaminated Wastes," Battelle Pacific Northwest Laboratories, BNWL-1730, April 1973.

National Safety Council, 1990. "Accidents Facts," 1990 Edition, Chicago, IL.

Reilly, T. A. 1982. "Nuclear Criticality Safety in Shipping Radioactive Waste To Building 643G," Memorandum to J. L. Forstner, DPSPU-82-272-103, August 11, 1982.

Shappell, J. R. 1993. "Waste Management Occurrence Report," Report Number SRS-SLDHZD92-1009, Savannah River Site, Westinghouse Savannah River Company, Final Report, July $20,1993$.

Sherman, M. P. 1984. "Hydrogen Combustion in Nuclear Plant Accidents and Associated Containment Loads," Sandia National Laboratories, Nuclear Engineering and Design Vol. 82 .

Thomas, J. K. and Hensel, S. J. 1993. "Pressure Resulting From an ITP Waste Tank Deflagration (U)", WSRC-RP-93-543, Westinghouse Savannah River Company, Savannah River Site, Aiken, SC, April 1993.

U. S. DOC, 1990. "Statistical Abstract of the United States," The National Data Book, U. S. Department of Commerce, Bureau of the Census.

U. S. DOE, 1993. "Fire, Explosion, and High-Pressure Hazards Associated with Waste Drums and Containers," Safety Notice, Issue No. 93-1, Office of Nuclear Safety, United States Department of Energy, Washington, DC, February 1993. 
U. S. DOE, 1993a. "Hazard Categorization and Accident Analysis Techniques for Compliance with DOE Order 5480.23, Nuclear Safety Analysis Reports," DOE-STD-1027-92, U. S. Department of Energy, Washington, D. C., December 1992.

U. S. DOE, 1993b. "DOE Handbook: Recommended Values and Technical Bases for Airborne Release Fractions (ARFs), Airborne Release Rates (ARRs), and Respirable Fractions (RFs) at DOE Non-Reactor Nuclear Facilities," DOE-HDBK-0013-93, U. S. Department of Energy, Washington, D. C. July 1993.

U. S. DOE, 1994. "Evaluation Guidelines for Accident Analysis and Safety Structures, Systems, and Components," DOE-STD-3005-YR Proposed, U. S. Department of Energy, Washington, D. C., February 25, 1994.

WHC (Westinghouse Hanford Company) 1992. "Final Safety Analysis for Contact-Handled, Transuranic Waste Drum in Situ Inspection and Vented Drum Retrieval," WHC-SD-WMSAR-058 Rev. 0, Westinghouse Hanford Company, October 1992.

Williams, L. 1991. "Covered Culvert Temperature Assessment (U)", WSRC-TR-91-575, Memorandum to M. G. Looper, October 11, 1991.

Wilson, B. L. 1993. "Safety Evaluation Information Input for TRU Retrieval," Memorandum to M. S. Rabin, SWE-SWE-93-0539, October 7, 1993.

WSRC, 1993a. "Functional Design Criteria, Project S-2991, Transuranic Waste Facility Phase 1: Retrieval (U)," Westinghouse Savannah River Company, Savannah River Site, M-FDC-E00001 Rev. 0, May 17, 1993.

WSRC (Westinghouse Savannah River Company) 1993b. "Functional Classification Methodology Manual," WSRC-TM-93-3, June 14, 1993. 
WSRC-TR-93-451

Rev. 2

Appendix A - Fault Tree Analysis For Drum Deflagration

A-1 


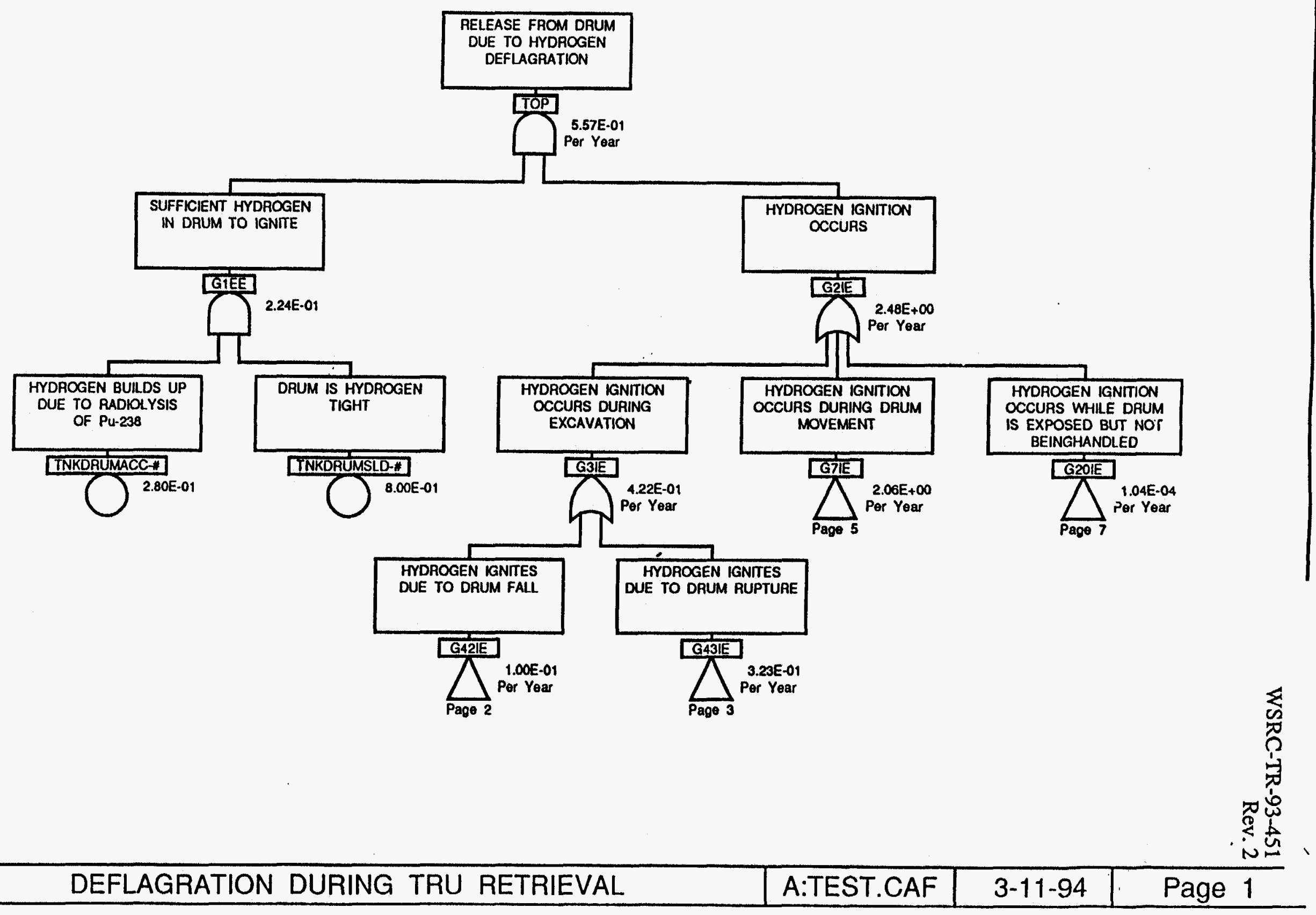



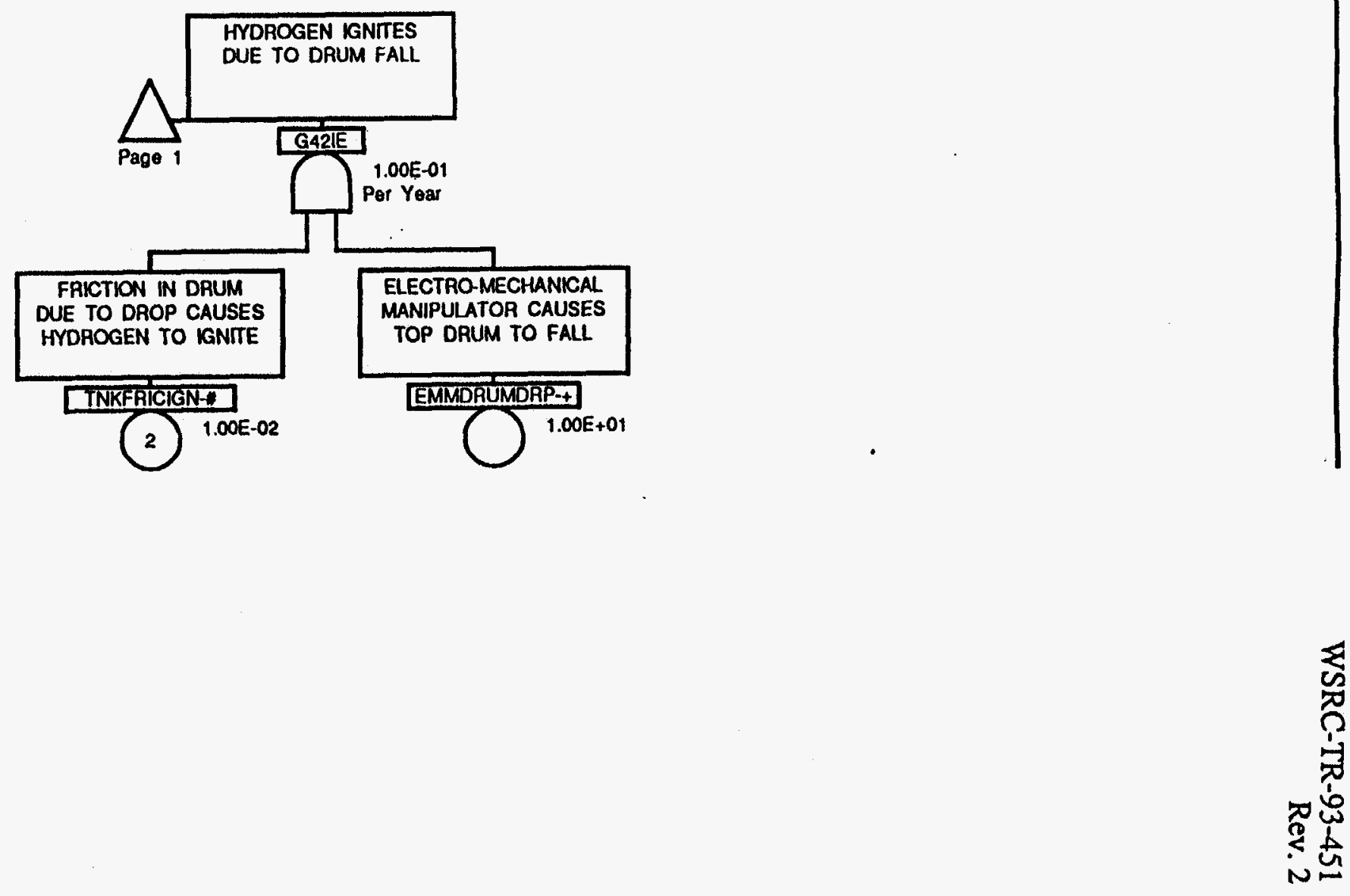
WSRC-TR-93-451

Rev. 2

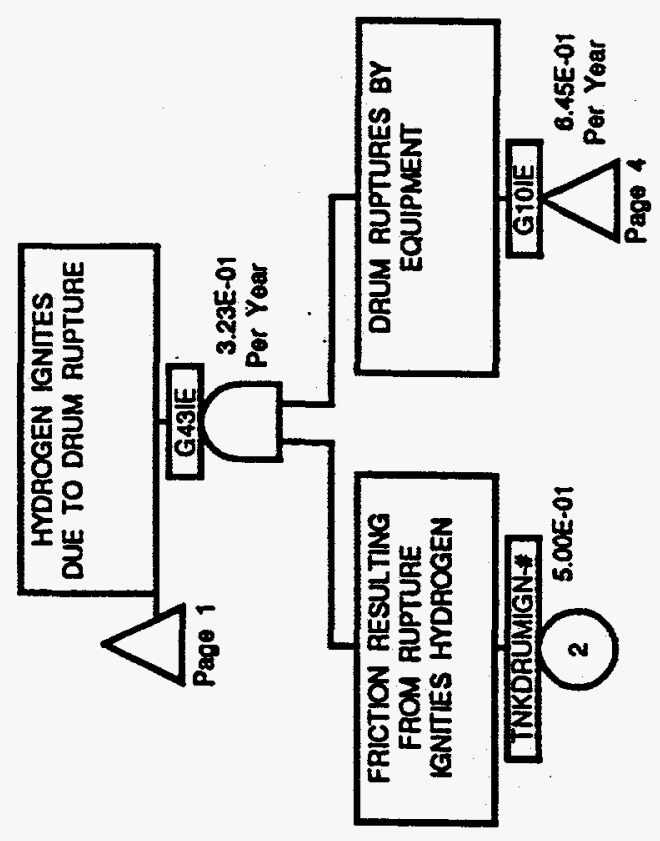

क

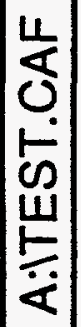

京

$\vec{\sigma}$

ㄸㅗㅏ 


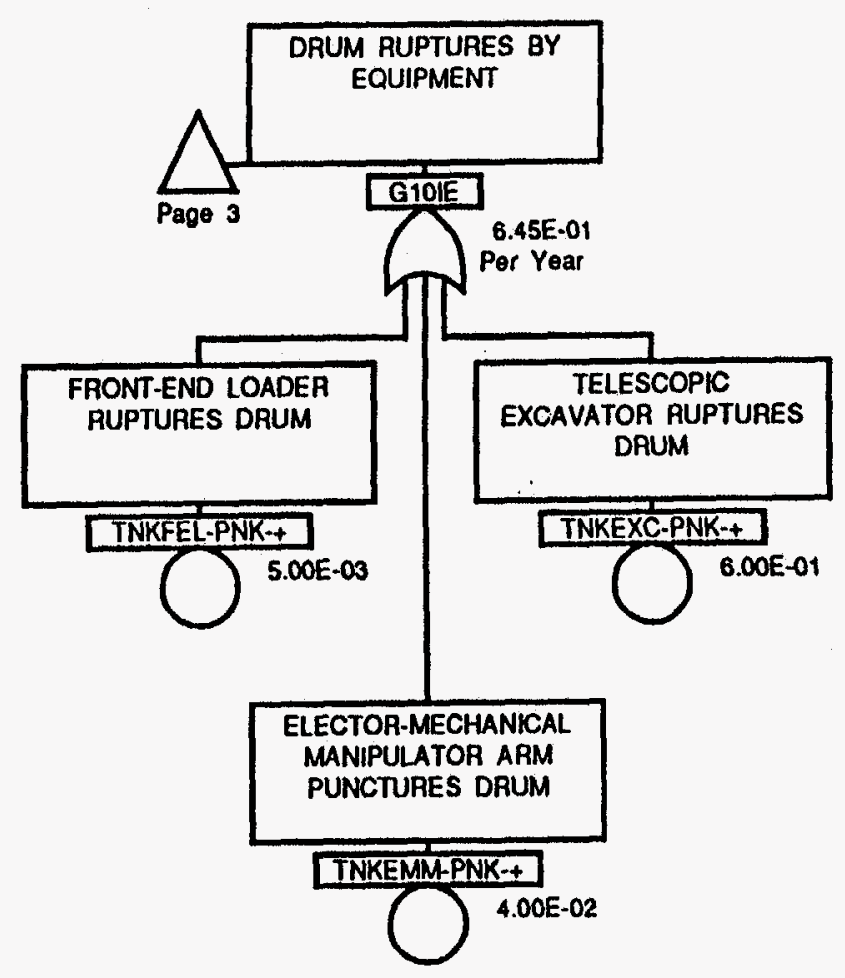




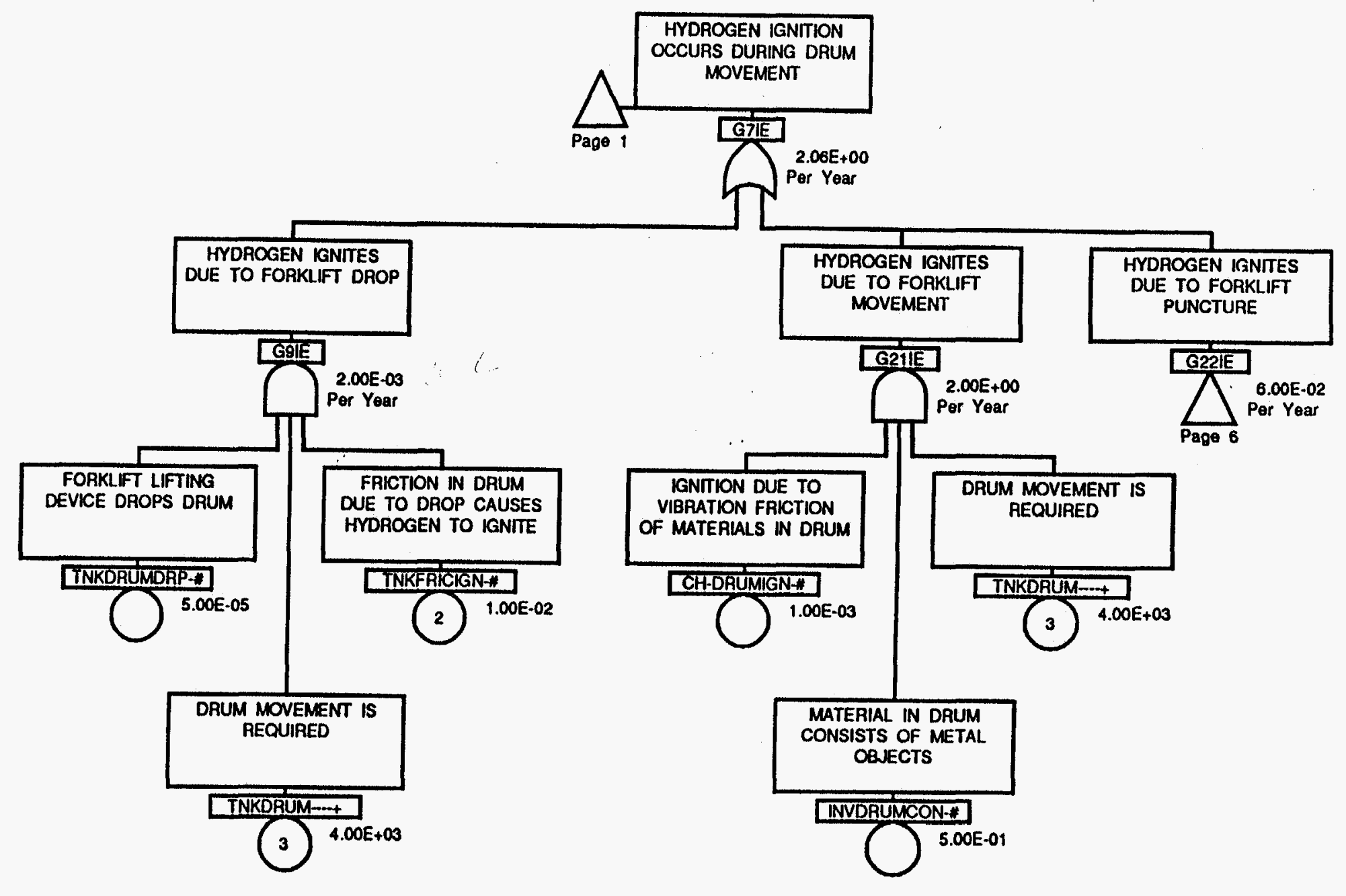




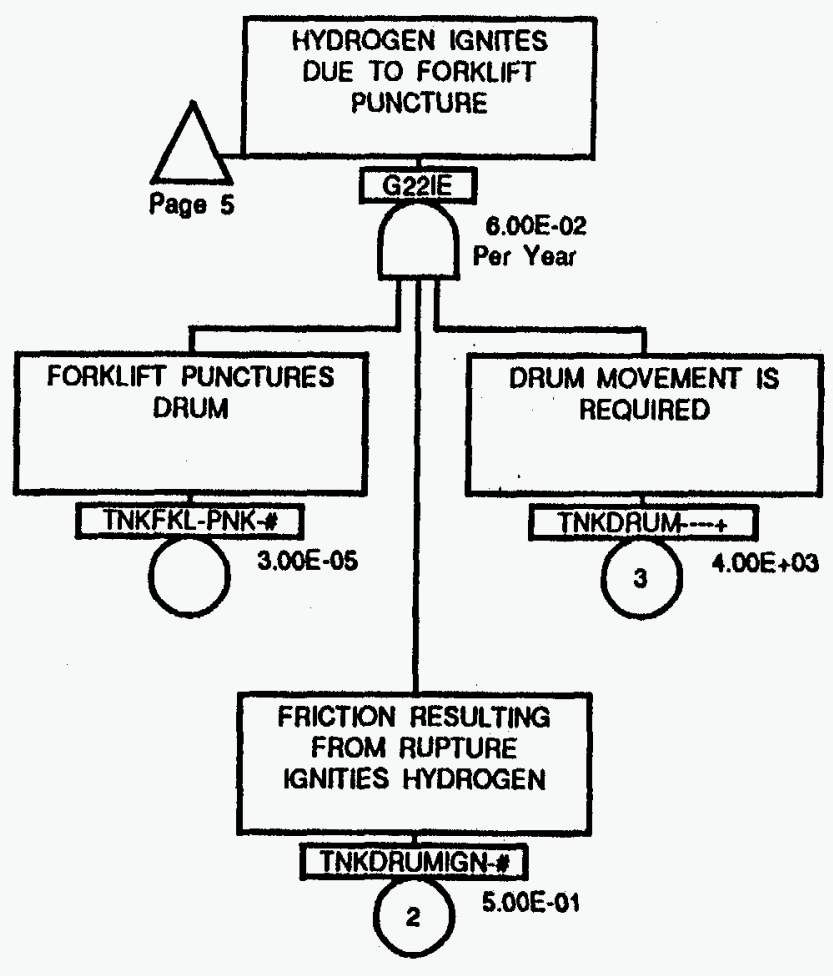




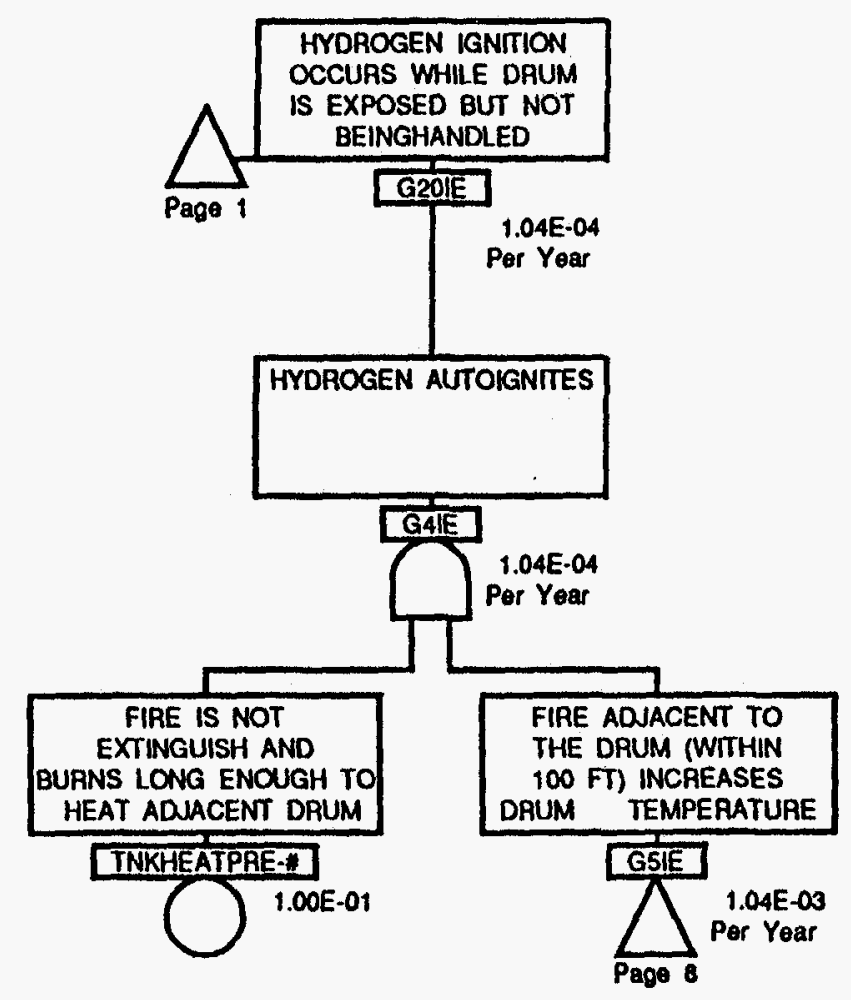




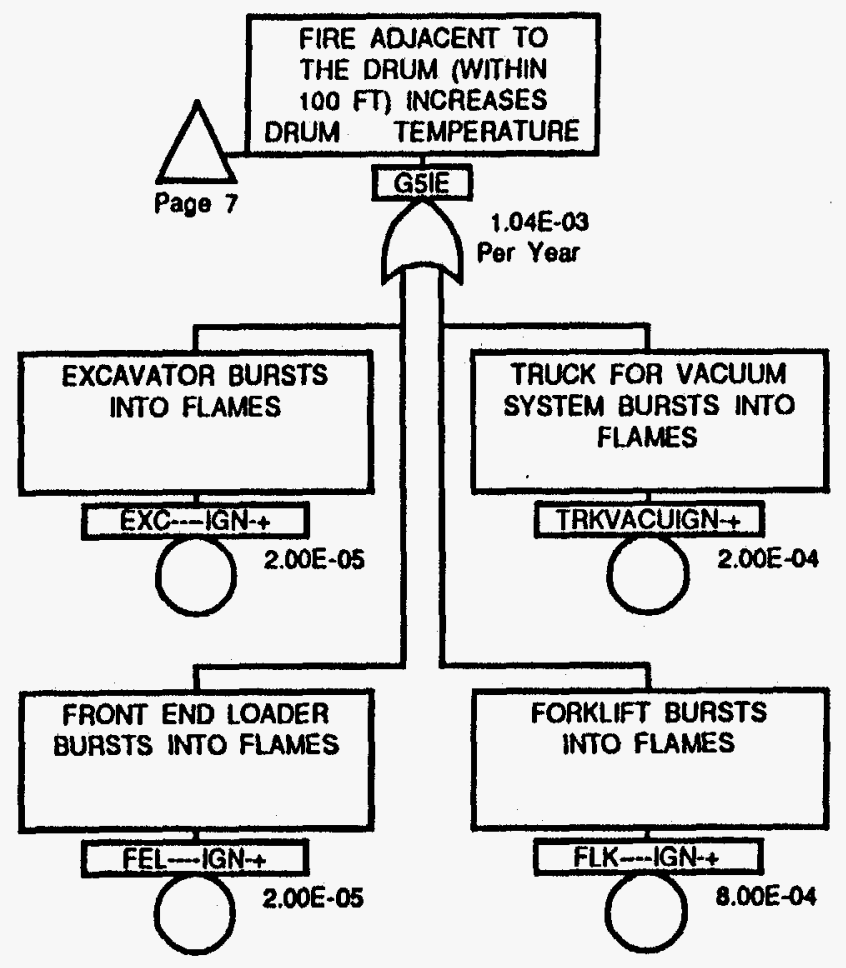


Cutsets for TRU Deflagration

\begin{tabular}{|c|c|c|c|c|c|c|}
\hline $\begin{array}{l}\text { Set } \\
\text { No. }\end{array}$ & $\begin{array}{l}\text { Event } \\
\text { Name }\end{array}$ & Description & C) & $\begin{array}{l}\text { B.E. } \\
\text { Input }\end{array}$ & $\begin{array}{r}\text { Calc. } \\
\text { Result }\end{array}$ & $\begin{array}{c}\text { Cutset } \\
\text { Freq. }(/ y r)\end{array}$ \\
\hline & TOP & & & & & $5.57 \mathrm{E}-01$ \\
\hline 1. & $\begin{array}{l}\text { CH-DRUMIGN- } \\
\text { INVDRUMCON- } \\
\text { TNKDRUM--1 } \\
\text { TNKDRUMACC- } \\
\text { TNKDRUMSLD- }\end{array}$ & $\begin{array}{l}\text { IGNITION DUE TO VIBRATION FRICTION OF MATERIALS IN DRUM } \\
\text { MATERIAL IN DRUM CONSISTS OF METAL OBJECTS } \\
\text { DRUM MOVEMENT IS REQUIRED } \\
\text { HYDROGEN BUILDS UP DUE TO RADIOLYSIS OF PU-238 } \\
\text { DRUM IS HYDROGEN TIGHT }\end{array}$ & & $\begin{array}{r}1 E-3 N \\
5 E-1 N \\
4 E+3 Y \\
8 E-1 N \\
8 E-1 N\end{array}$ & $\begin{array}{l}1.00 \mathrm{E}-03 \\
5.00 \mathrm{E}-01 \\
4.00 \mathrm{E}+03 \mathrm{Y} \\
2.80 \mathrm{E}-01 \\
8.00 \mathrm{E}-01\end{array}$ & $4.48 \mathrm{E}-01$ \\
\hline 2. & $\begin{array}{l}\text { TNKDRUMACC- } \\
\text { TNKDRUMIGN- } \\
\text { TNKDRUMSLD- } \\
\text { TNKEXC-PNK- }\end{array}$ & $\begin{array}{l}\text { HYDROGEN BUILDS UP DUE TO RADIOLYSIS OF PU-238 } \\
\text { FRICTION RESULTING FROM RUPTURE IGNITIES HYDROGEN } \\
\text { DRUM IS HYDROGEN TIGHT } \\
\text { TELESCORIC EXCAVATOR RUPTURES DRUM }\end{array}$ & & $\begin{array}{r}8 E-1 N \\
5 E-1 N \\
8 E-1 N \\
6 E-1 Y\end{array}$ & $\begin{array}{l}\text { 2.8OE-01 } \\
5.00 E-01 \\
\text { 8.00E-01 } \\
6.00 E-01 Y\end{array}$ & $6.72 \mathrm{E}-02$ \\
\hline 3. & $\begin{array}{l}\text { EMMDRUMDRP- } \\
\text { TNKDRUMACC- } \\
\text { TNKDRUMSID- } \\
\text { TNKFRICIGN- }\end{array}$ & $\begin{array}{l}\text { ELECTRO-MECHANICAL MANIPULATOR CAUSES TOP DRUM TO FALL } \\
\text { HYDROGEN BUILDS UP DUE TO RADIOLYSIS OF PU-238 } \\
\text { DRUM IS HYDROGEN TIGHT } \\
\text { FRICTION IN DRUM DUE TO DROP CAUSES HYDROGEN TO IGNITE }\end{array}$ & & $\begin{array}{r}1 E+1 Y \\
8 E-1 N \\
8 E-1 N \\
1 E-2 N\end{array}$ & $\begin{array}{l}1.00 E+01 Y \\
2.80 \mathrm{E}-01 \\
8.00 \mathrm{E}-01 \\
1.00 \mathrm{E}-02\end{array}$ & $2.24 E-02$ \\
\hline 4. & $\begin{array}{l}\text { TNKDRUM----t } \\
\text { TNKDRUMACC- } \\
\text { TNKDRUMIGN- } \\
\text { TNKDRUMSLD-1 } \\
\text { TNKFKL-PNK-1 }\end{array}$ & $\begin{array}{l}\text { DRUM MOVEMENT IS REQUIRED } \\
\text { HYDROGEN BUILDS UP DUE TO RADIOLYSIS OF PU-238 } \\
\text { ERICTION RESULTING FROM RUPTURE IGNITIES HYDROGEN } \\
\text { DRUM IS HYDROGEN TIGHT } \\
\text { EORKLIFT PUNCTURES DRUM }\end{array}$ & & $\begin{array}{r}4 E+3 Y \\
8 E-1 N \\
5 E-1 N \\
8 E-1 N \\
3 E-5 N\end{array}$ & $\begin{array}{l}\text { 4.0OE+03Y } \\
2.80 \mathrm{E}-01 \\
5.00 \mathrm{E}-01 \\
\text { 3.00E-01 } \\
\text { 3.00E-05 }\end{array}$ & $1.34 E-02$ \\
\hline 5. & $\begin{array}{l}\text { TNKDRUMACC- } \\
\text { TNKDRUMIGN- } \\
\text { TNKDRUMSLD- } \\
\text { TNKEMM-PNK-+ }\end{array}$ & $\begin{array}{l}\text { HYDROGEN BUILDS UP DUE TO RADIOLYSIS OF PU-238 } \\
\text { FRICTION RESULTING FROM RUPTURE IGNITIES HYDROGEN } \\
\text { DRUM IS HYDROGEN TIGHT } \\
\text { ELECTOR-MECHANICAL MANIPULATOR ARM PUNCTURES DRUM }\end{array}$ & & $\begin{array}{r}8 E-1 N \\
5 E-1 N \\
8 E-1 N \\
4 E-2 Y\end{array}$ & $\begin{array}{l}2.80 \mathrm{E}-01 \\
5.00 \mathrm{E}-01 \\
8.00 \mathrm{E}-01 \\
4.00 \mathrm{E}-02 \mathrm{Y}\end{array}$ & $4.48 \mathrm{E}-03$ \\
\hline 6. & $\begin{array}{l}\text { TNKDRUMACC- } \\
\text { TNKDRUMIGN-1 } \\
\text { TNKDRUMSLD-1 } \\
\text { TNKFEL-PNK-† }\end{array}$ & $\begin{array}{l}\text { HYDROGEN BUILDS UP DUE TO RADIOLYSIS OF PU-238 } \\
\text { FRICTION RESULTING EROM RUPTURE IGNITIES HYDROGEN } \\
\text { DRUM IS HYDROGEN TIGHT } \\
\text { FRONT-END LOADER ROPTURES DRUM }\end{array}$ & & $\begin{array}{r}8 E-1 N \\
5 E-1 N \\
8 E-1 N \\
5 E-3 Y\end{array}$ & $\begin{array}{l}2.80 \mathrm{E}-01 \\
5.00 \mathrm{E}-01 \\
8.00 \mathrm{E}-01 \\
5.00 \mathrm{E}-03 \mathrm{Y}\end{array}$ & $5.60 E-04$ \\
\hline 7. & $\begin{array}{l}\text { TNKDRUM---t } \\
\text { TNKDRUMACC- } \\
\text { TNKDRUMDRP- } \\
\text { TNKDRUMSLD- } \\
\text { TNKFRICIGN- }\end{array}$ & $\begin{array}{l}\text { DRUM MOVEMENT IS REQUIRED } \\
\text { HYDROGEN BUILDS UP DUE TO RADIOLYSIS OF PU-238 } \\
\text { EORKLIFT LIFTING DEVICE DROPS DRUM } \\
\text { DRUM IS HYDROGEN TIGHT } \\
\text { ERICTION IN DRUM DUE TO DROP CAUSES HYDROGEN TO IGNITE }\end{array}$ & & $\begin{array}{r}4 E+3 Y \\
2.8 E-1 N \\
5.0 E-5 N \\
8 E-1 N \\
1 E-2 N\end{array}$ & $\begin{array}{l}4.00 \mathrm{E}+03 \mathrm{Y} \\
2.80 \mathrm{E}-01 \\
5.00 \mathrm{E}-05 \\
8.00 \mathrm{E}-01 \\
1.00 \mathrm{~B}-02\end{array}$ & $4.48 E-04$ \\
\hline 8. & $\begin{array}{l}\text { FLK--O-TGN-+ } \\
\text { TNKDRUMACC- } \\
\text { TNKDRUMSLD- } \\
\text { TNKHEATERE- }\end{array}$ & $\begin{array}{l}\text { FORKLIFT BURSTS INTO ELAMES } \\
\text { HYDROGEN BUILDS UP DUE TO RADIOLYSIS OF PU- } 238 \\
\text { DRUM IS HYDROGEN TIGHT } \\
\text { FIRE IS NOT EXTINGUISH AND BURNS LONG ENOUGH TO HEAT } \\
\text { ADJACENT DRUM }\end{array}$ & & $\begin{array}{r}8 E-4 Y \\
2.8 E-1 N \\
8 E-1 N \\
1 E-1 N\end{array}$ & $\begin{array}{l}8.00 \mathrm{E}-04 \mathrm{Y} \\
2.80 \mathrm{E}-01 \\
8.00 \mathrm{E}-01 \\
1.00 \mathrm{E}-01\end{array}$ & $1.79 \mathrm{E}-05$ \\
\hline 9. & $\begin{array}{l}\text { TNKDRUMACC- } \\
\text { TNKDRUMSLD- }\end{array}$ & $\begin{array}{l}\text { HYDROGEN BUILDS UP DUE TO RADIOLYSIS OF PU-238 } \\
\text { DRUM IS HYDROGEN TIGHT }\end{array}$ & & $\begin{array}{r}8 E-1 N \\
8 E-1 N\end{array}$ & $\begin{array}{l}2.80 E-01 \\
8.00 E-01\end{array}$ & $4.48 E-06$ \\
\hline
\end{tabular}


Cutsets for TRU Deflagration (CONT.)

\begin{tabular}{|c|c|c|c|c|c|c|}
\hline $\begin{array}{l}\text { Set } \\
\text { No. }\end{array}$ & $\begin{array}{l}\text { Event } \\
\text { Name }\end{array}$ & Description & C & $\begin{array}{l}\text { B.E. } \\
\text { Input }\end{array}$ & $\begin{array}{l}\text { Calc. } \\
\text { Resuit }\end{array}$ & $\begin{array}{c}\text { Cutset } \\
\text { Freq. }(/ Y x)\end{array}$ \\
\hline 10 & $\begin{array}{l}\text { TNKHEATPRE- } \\
\text { TRKVACUTGN-+ } \\
\text { EXC--DIGN-+ } \\
\text { TNKDRUMACC- } \\
\text { TNKDRUMSLD- } \\
\text { TNKHEATPRE- }\end{array}$ & $\begin{array}{l}\text { FIRE IS NOT EXTINGUISH AND BURNS LONG ENOUGH TO HEAT } \\
\text { ADJACENT DRUM } \\
\text { TRUCK FOR VACUUM SYSTEM BURSTS INTO FLAMES } \\
\text { EXCAVATOR BURSTS INTO FIAMES } \\
\text { HYDROGEN BUILDS UP DUE TO RADIOLYSIS OF PU-238 } \\
\text { DRUM IS HYDROGEN TIGHT } \\
\text { FIRE IS NOT EXTINGUISH AND BURNS LONG ENOUGH TO HEAT } \\
\text { ADJACENT DRUM }\end{array}$ & & $\begin{array}{r}1 E-1 N \\
2 E-4 Y \\
2 E-5 Y \\
2.8 E-1 N \\
8 E-1 N \\
1 E-1 N\end{array}$ & $\begin{array}{l}1.00 E-01 \\
2.00 E-04 Y \\
2.00 E-05 Y \\
2.80 E-01 \\
8.00 E-01 \\
1.00 E-01\end{array}$ & $4.48 \mathrm{E}-07$ \\
\hline 11. & $\begin{array}{l}\text { EEL----IGN-t } \\
\text { TNKDRUMACC- } \\
\text { TNKDRUMSLD- } \\
\text { TNKHEATRRE- }\end{array}$ & $\begin{array}{l}\text { FRONT END LOADER BURSTS INTO FLAMES } \\
\text { HYDROGEN BUILDS UP DUE TO RADIOLYSIS OF PU-238 } \\
\text { DRUM IS HYDROGEN TIGHT } \\
\text { FIRE IS NOT EXTINGUISH AND BURNS LONG ENOUGH TO HEAT } \\
\text { ADJACENT DRUM }\end{array}$ & & $\begin{array}{r}2 E-5 Y \\
2.8 E-1 N \\
8 E-1 N \\
1 E-1 N\end{array}$ & $\begin{array}{l}2.00 E-05 Y \\
2.80 E-01 \\
8.00 E-01 \\
1.00 E-01\end{array}$ & $4.48 E-07$ \\
\hline
\end{tabular}




\section{Description of Basic Events - Justification for frequencies/probabilities}

drum. For purposes of this initial analysis it is assumed that if a fire occurs within 100 $\mathrm{ft}$ of the drum the hydrogen inside the drum will ignite due to the increase in temperature. See attached calculation sheet for derivation of this number.

\section{E-5yr} FEL-.--IGN-+ $\begin{aligned} & \text { Front end loader burst into } \\ & \text { flames }\end{aligned}$

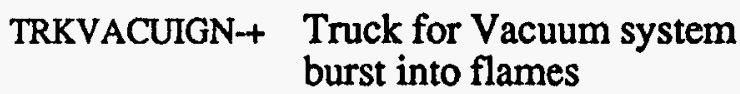

FKL----IGN-+ Forklift burst into flames

This is the frequency that the front end loader will catch on fire within $100 \mathrm{ft}$ of the drum. For purposes of this initial analysis it is assumed that if a fire occurs within 100 $\mathrm{ft}$ of the drum the hydrogen inside the drum will ignite due to the increase in temperature. See attached calculation sheet for derivation of this number.

\section{E-5yr}

This is the frequency that the vacuum truck will catch on fire within $100 \mathrm{ft}$ of the drum. For purposes of this initial analysis it is assumed that if a fire occurs within $100 \mathrm{ft}$ of the drum the hydrogen inside the drum will ignite due to the increase in temperature. See attached calculation sheet for derivation of this number.

\section{$2 \mathrm{E}-4$}

This is the frequency that the forklift will catch on fire within $100 \mathrm{ft}$ of the drum. For purposes of this initial analysis it is assumed that if a fire occurs within $100 \mathrm{ft}$ of the drum the hydrogen inside the drum will ignite due to the increase in temperature. See attached calculation sheet for derivation of this number.

\section{$8 \mathrm{E}-4 / \mathrm{yr}$}

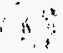

TNKHEATPRE\# Fire is not extinguished and burns long enough to heat adjacent drum

It is assumed that each piece of equipment will be equipped with a fire extinguisher and other fire extinguishers will be placed in strategic places within the weather containment hut. The burn time required for an adjacent fire to raise the temperature in a drum is 10 minutes. The probability that personnel or the fire department will not be able to respond to and extinguish a fire within 10 minutes is $1 \mathrm{E}-1$. 


\section{Description of Basic Events - Justification for frequencies/probabilities}

CH-DRUMIGN-\# Movement of drum causes This represents the probability/frequency that the movement of the drum will cause the an ignition due to friction of material inside to shift sufficiently to cause the metal material to flash. Friction is a materials in drum very inefficient source of an ignition source. Based on practical experience, under ideal situations, the probability of creating an ignition source from the movement of drums is considered to be low. A probability of 1E-3 is assigned to this event. This probability is considered conservative since the waste is placed in layers of plastic and the drum is lined with a 90 mil plastic liner, both of which will have cushioning effects. 1E-3

INVDRUMCON-\# Material in drum consists of Since the contents of each drum is unknown and can vary widely in material types (i.e. metal objects plastics, cloth, wood, cans, tools, etc...) it is assumed that there is a 50\% probability that the drum will contain metal objects that are capable of creating sufficient friction which could ignite the mixture of Hydrogen and oxygen if the drums are jolted. 0.5

TNKDRUM - + Frequency of drum Movement

TNKFKL-PNK-\# Forklift punctures drum

TNKDRUMDRP-\# Forklift/lifting device drops drum
The number of drum movements per year is assumed to be 2,000. However, for the deflagration scenario, each drum will have to be picked up, placed in an overpack and then the overpacked drum will be picked up and moved to the vent and purge station. In determining probabilities, a drum movement (or operation) is defined as a lift, move, and setting down of a load. Since the drums will be lifted and set down twice before being purged, the drum movements are estimated as: 4,000 drum movements/year

This represents the probability that a forklift will puncture a drum being lifted or an adjacent drum during drum movements. Based on information provided in the Savannah River Site Human Error Data Base Development for Nonreactor Nuclear Facilities $(U)$ WSRC-TR-93-581, February 1994, the probability for this event was determined to be $\mathbf{5 E}-5$.

This represents the probability that a forklift will drop a drum being lifted. Based on information provided in the Savannah River Site Human Error Data Base Development for Nonreactor Nuclear Facilities (U) WSRC-TR-93-581, February 1994, the probability for this event was determined to be 5E-5. 


\section{Description of Basic Events - Justification for frequencies/probabilities}

Name

TNKFRICIGN-\#

Friction in drum causes hydrogen to ignite

TNKFEL-PNK-+ Frontend loader Ruptures drum

TNKEXC-PNK-+ Telescopic excavator ruptures drum

TNKEMM-PNK- Electro-mechanical manipulator ruptures drum

TNKDRUMIGN-\# Friction resulting from puncture ignites hydrogen
Frequency/Probability Calculation

This is the probability that the friction in the drum, which is caused by a dropped drum, causes an electric spark which ignites the hydrogen mixture inside the drum. The maximum height that a drum could fall is $4 \mathrm{ft}$. Waste inside the drum was wrapped in polyethylene which is placed in the 90 -mil polyethylene liner. Based on these considerations a probability of 1E-2 was assigned for this event.

The probability that the frontend loader ruptures a drum is small, since the frontend loader will be moving some of the side burden and will be used mostly for clean-up work, it should have very little movement close to the drums. In addition, it is assumed that there will always be a spotter that will identify the depth to the drums when the frontend loader is working near the drums. This probability is assumed to be 1E-5. Based on 500 hours of operation (it is conservatively assumed that the backhoe will operate $25 \%$ during retrieval duration) this results in a frequency of $5 \mathrm{E}-3 / \mathrm{yr}$.

The probability that the telescopic excayator will puncture a drum is greater than that assumed for the backhoe, since the telescopic excavator will be excavating soil within approximately 6 inches of the drums. The probability is assumed to be 1E-3. The telescopic excavator is assumed to operate $30 \%$ of the time in a range that could puncture the drum. This results in a frequency of $6 \mathrm{E}-1 / \mathrm{yr}(1 \mathrm{E}-3 / \mathrm{hr} * 2000 \mathrm{hrs} / \mathrm{yr} * .30)$.

The probability that the electro-mechanical manipulator will rupture a drum is considered to be small. It is more likely that the electro-mechanical manipulator would cause the drum to topple. However, if the operator of the manipulator lowered the arm to which the free end of the vacuum hose is attached with sufficient force, there is a potential for the arm to puncture the drum. since this activity will be a more precise equipment maneuver. The probability is assumed to be 1E-4. The number of hours of operation are assumed to be $20 \%$ of $2000 \mathrm{hrs}$. which results in a frequency of $4 \mathrm{E}-2 / \mathrm{yr}$

This represents the probability that the friction (or tearing) caused by an equipment puncture will cause the hydrogen mixture inside the drum to ignite.

5E-1 


\section{Description of Basic Events - Justification for frequencies/probabilities}

TNKDRUMACC- Hydrogen builds up due to \# radiolysis of $\mathrm{Pu}-238$
EMMDRUMDRP- Electro-mechanical

TNKDRUMSLD-\# Drum is hydrogen tight
Based on the uncertainty in the generators assay equipment and the suspected errors in the COBRA database the inventory of each drum that was generated in HB-Line is assumed to be 20 curies of $\mathrm{Pu}-238$. The radiolysis of $\mathrm{Pu}-238$ will break down the organic material in the drum and generate hydrogen. The hydrogen concentrations are assumed to be at $12 \% \mathrm{v} / \mathrm{v}$. COBRA records indicate that approximately $13 \%$ of the pad drums were generated in HB-Line. In addition, COBRA records were searched to find the percentage of pad drums containing $\mathrm{Pu}-238$ from all generators. This search resulted in $28 \%$. For conservatism, it is assumed that $28 \%$ of the pad drums contain 20 curies of $\mathrm{Pu}-238$; therefore, the probability that hydrogen could be generated to a flammable concentration is $\mathbf{0 . 2 8}$.

The probability that the electro-mechanical manipulator will cause a drum to fall during the vacuum operation was assigned as $1 \mathrm{E}-2$. It is likely that only the top drums on the stack will be knocked over by the manipulator. The frequency was calculated by multiplying the probability by one half of the drum retrieval rate $(1 \mathrm{E}-2 * 1000$ drums/year). 1E+01/yr Although the probability of hydrogen generation is 1 , it is likely that all of the drums are not capable of containing the hydrogen that is generated. Hydrogen may escape via "through wall pits" caused by corrosion. Since the drums have been buried for approximately 20 years, it is assumed that $20 \%$ of the drums have sufficient corrosion to cause hydrogen to escape. The probability therefore, that the drums are hydrogen tight was assumed to be $8 \mathrm{E}-1$. 


\section{Frequency Calculation for equipment fires near the TRU drums being retrieved:}

A SRS data bank search was performed for transportation type accidents (source codes searched were $M$ and 076 ). This sort produced approximately 138 incidents of fires in government vehicles ranging from cushmans to tractor trailer trucks. Most of the fires that were identified in the data bank were extinguished by personnel with a fire extinguisher at the site of the fire, very few were required to be extinguished by the SRS fire department. Less than $10 \%$ of the incidents reported caused damage that was greater than $\$ 1,000$. In addition, many of the fires were started with cigarettes; the WSRC policy no longer permits smoking in government vehicles, estimation of the frequencies as described below are considered conservative.

The equipment that will be operating near the unvented drums (within $100 \mathrm{ft}$ of the drums)during retrieval activities includes:

diesel powered telescoping excavator

truck for moving dirt

small front-end loader

fuel powered vacuum truck

battery powered forktruck

The frequency for a fire occurring within 100 feet of an uncovered drum is determined based on the data bank search and conditional probabilities for each piece of equipment. The conditional probability takes into account the \% of time the piece of equipment will be within 100 feet of the uncovered drum. It is assumed that the soil cover over a drum will protect the drum from a fire.

The total number of government vehicles onsite (including forklifts, backhoes, etc...) is 2,500 . The frequency of a fire in any one government vehicle was determined to be $2 \mathrm{E}-3$ fires per year (138 incidents reported/28 years of data/2500 vehicles). .

Forklift: Out of the data bank search only 6 forklift fires were reported in 28 years worth of entries. There are approximately 160 (WSRC) forklifts on site. Calculation of the frequency for any one forklift to catch on fire is $1.3 \mathrm{E}-3$ per year ( 6 forklift fires $\div 28$ years of data +160 WSRC forklifts). This frequency is comparable to the general frequency for all types of government vehicles as shown in the previous paragraph. To this frequency, a conditional probability was applied to account for the percentage of time the forklift would be within $100 \mathrm{ft}$ of an unvented drum. Since the forklift will pickup the unvented drum and carry it to the vent and purge station and then return with out a load to the next uncovered (and unvented) drum it was assumed that only $60 \%$ of the operating time would be within $100 \mathrm{ft}$ of a drum. Thus, the frequency of a forklift fire within 100 feet of an unvented drum is 8E-4 year.

Front end loader: The frequency for any one piece of equipment to catch fire is assumed to be the same as that calculated above for any one government vehicle, 2E$3 /$ year. Since the front end loader will be excavating soil from all areas of the pad the amount of time the front end loader will be around an unvented drum is assumed to be proportional to a ratio of the pad area. A conditional probability of $1 \%$ (100 sq. feet around excavated drum $+9,000$ total sq. $\mathrm{ft}$. of a pad) was applied to the frequency. Thus the frequency of a front end loader within 100 feet of an unvented drum is 2E-5/year.

Vacuum truck: The frequency calculated for the vacuum truck really takes into account for the fact that periodically supervisor's trucks or maintenance trucks will be within 100 
feet of a drum. The frequency for any one piece of equipment to catch fire is assumed to be the same as that calculated above for any one government vehicle, $2 \mathrm{E}-3 /$ year. It is assumed, the vacuum truck, or some other truck will be within 100 feet from an uncovered drum approximately $10 \%$ of the time. The resultant frequency is $2 \mathrm{E}-4 / \mathrm{year}$.

Truck for moving dirt: The frequency for this is considered incredible since the trucks will not be within 100 feet of an uncovered drum.

Telescoping excavator: The frequency of fires for the telescoping excavator is assumed to be the same as the front end loader. This frequency is considered conservative since the excavator will not be used to remove the last six inches of soil and will be exposed to very few uncovered drums. $2 \mathrm{E}-5 /$ year. 
WSRC-TR-93-451

Rev. 2

Appendix B - Uncertainty Analysis

B-1 


\section{Summary of Uncertainty Analysis:}

The uncertainty analysis was performed on the drum deflagration scenario (fault tree) frequency calculation since many of the input data into the fault tree analysis is not available in the SRS fault tree data banks. By performing an uncertainty analysis, a range can be assigned to the input data (basic events) rather than a single point. A log normal distribution was assigned to each basic event since the fault tree program is based on $\log$ normal distributions. For some basic events, there was high confidence that the range was small. In these cases, the end points of the log normal distribution were adjusted accordingly.

This uncertainty analysis provides a distribution of the frequency for the drum deflagration by randomly sampling each of the parameters for 5,000 iterations of the calculation. Two results from the uncertainty analysis are of particular interest for the safety evaluation: the calculated mean frequency of drum deflagrations and the $95 \%$ upper confidence limit for the frequency. For purposes of this evaluation, the $95 \%$ was used as a bounding case. For safety analyses, the mean frequencies are used with maximum consequences to determine risk, as well as the upper bound frequencies used with mean consequences. This evaluation provides a bounding estimnte of risk by using upper bound frequencies with maximum consequences. 
Crystal Ball@ Simulation

Started on Fri, Mar 11, 1994 at 10:15:02 AM

Stopped on Fri, Mar 11, 1994 at 10:27:31 AM

Forecast: Frequency for Drum Deflagration

Cell: B46

Summary: Certainty Level is $100.00 \%$ based on Entire Range

Certainty Range is from $-\infty$ to $\infty$ drum deflagrations/year

Display Range is from $0.00 E+0$ to $1.50 E+0$ drum deflagrations/year

Entire Range is from 1.44E-6 to $1.99 \mathrm{E}+1$ drum deflagrations/year

After 5,000 Trials, the Std. Error of the Mean is 0.01

Statistics:

Trials

Percent of Other

Mean

Median

Mode

Standard Deviation

Variance

Skewness

Kurtosis

Coeff. of Variability

Range Width

Range Minimum

Range Maximum

Mean Std. Error
Display Range

4,957

99.14

6.10e-2

$1.24 \mathrm{e}-2$

$2.50 \mathrm{e}-3$

$1.50 \mathrm{e}-1$

$2.26 \mathrm{e}-2$

5.23

36.56

246.75

$1.50 \mathrm{e}+0$

$0.00 \mathrm{e}+0$

$1.50 \mathrm{e}+0$

0.00
Entire Range

5,000

100.87

$9.58 \mathrm{e}-2$

(unavailable)

(unavailable)

$5.37 \mathrm{e}-1$

$2.88 \mathrm{e}-1$

(unavailable)

(unavailable)

559.96

$1.99 e+1$

$1.44 \mathrm{e}-6$

$1.99 \mathrm{e}+1$

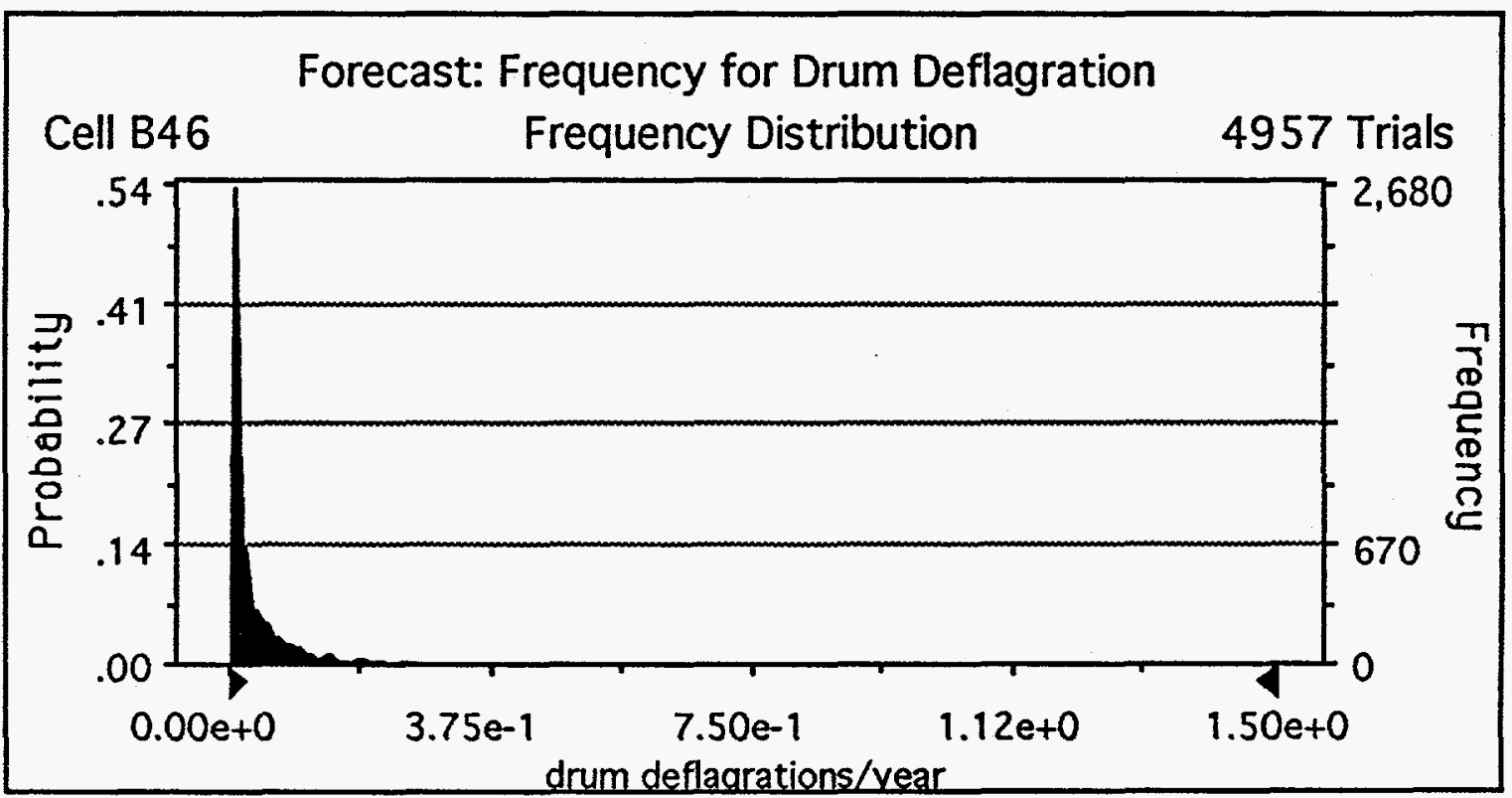


WSRC-TR-93-451

Rev. 2

Forecast: Frequency for Drum Deflagration (Cont'd)

Cell: 846

Percentiles for Entire Range (drum deflagrations/year):

Percentile

$0 \%$

$5 \%$

$25 \%$

$50 \%$

$75 \%$

$95 \%$

$100 \%$
Erequency for Drum Deflagration

$1.44 \mathrm{E}-6$

$4.18 \mathrm{E}-3$

$2.09 \mathrm{E}-2$

$4.18 \mathrm{E}-2$

$6.27 \mathrm{E}-2$

$3.31 \mathrm{E}-1$

$1.99 \mathrm{E}+1$

End of Forecast 


\section{Assumptions}

Assumption: $\quad$ A (TNKDRUM----+)

Lognormal distribution with parameters:

Mean

4.00E+3

Standard Dev.

$1.76 \mathrm{E}+3$

Selected range is from $0.00 E+0$ to $\infty$

Mean value in simulation was $4.01 \mathrm{E}+3$

Assumption: B (TNKDRUMACC-\#)

Lognormal distribution with parameters:

Mean

2.80E-1

Standard Dev.

9.36E-1

Selected range is from $0.00 E+0$ to $1.00 E+0$

Mean value in simulation was $1.47 \mathrm{E}-1$

Assumption: $\quad$ C (TNKDRUMIGN-\#)

Lognormal distribution with parameters:

Mean

Standard Dev.

5.00E-1

$1.87 \mathrm{E}+0$

Selected range is from $0.00 E+0$ to $1.00 E+0$ Mean value in simulation was $1.88 \mathrm{E}-1$

\section{Assumption: D (TNKDRUMSLD-\#)}

Lognormal distribution with parameters:

Mean

8.00E-1

Standard Dev.

$3.53 \mathrm{E}-1$

Selected range is from $0.00 E+0$ to $1.00 E+0$ Mean value in simulation was $6.46 \mathrm{E}-1$

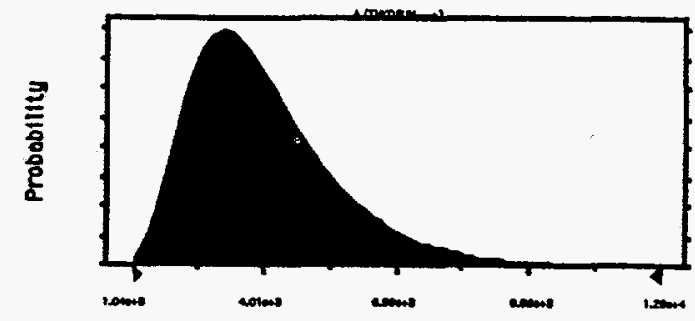

Cell: B12

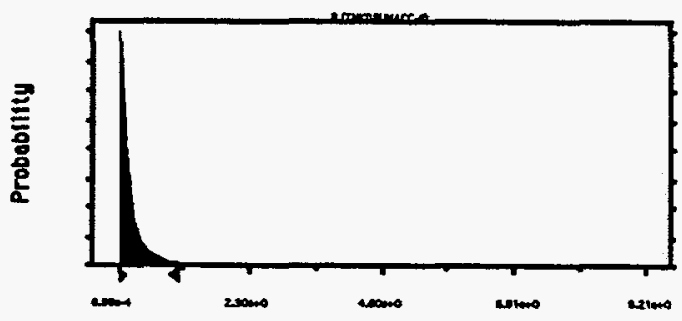

Cell: B13

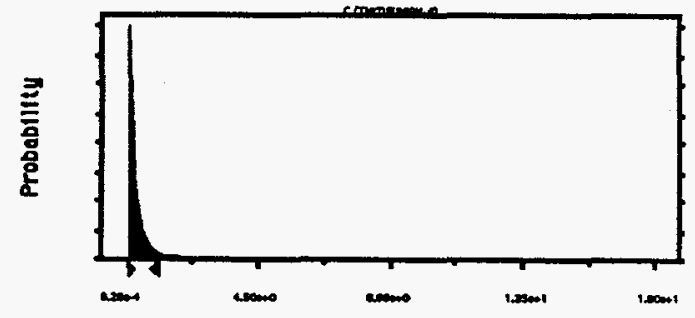

Cell: B14

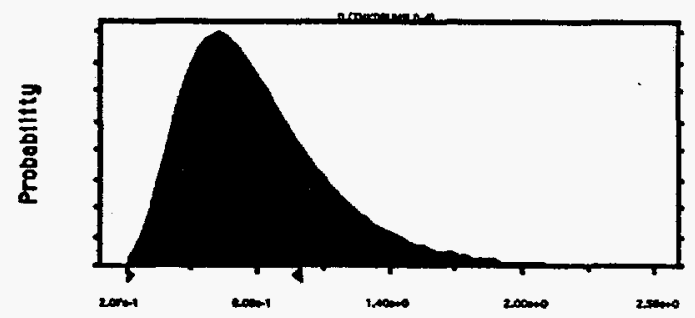


Lognormal distribution with parameters:

Mean

$3.00 \mathrm{E}-5$

Standard Dev.

$7.41 \mathrm{E}-5$

Selected range is from $0.00 E+0$ to $\infty$ Mean value in simulation was $2.98 \mathrm{E}-5$

Assumption: $\quad$ G (TNKEMM-PNK-+)

Lognormal distribution with parameters:

Mean

Standard Dev.

4.00E-2

$1.50 \mathrm{E}-1$

Selected range is from $0.00 E+0$ to $\infty$ Mean value in simulation was $4.28 \mathrm{E}-2$

Assumption: $\quad \mathrm{H}$ (TNKDRUMDRP-\#)

Lognormal distribution with parameters: Mean

$5.00 \mathrm{E}-5$ Standard Dev.

$1.23 E-4$

Selected range is from $0.00 E+0$ to $\infty$

Mean value in simulation was $4.96 \mathrm{E}-5$

\section{Assumption: I (TNKFRICIGN-\#)}

Lognormal distribution with parameters:

Mean

Standard Dev.

$1.00 \mathrm{E}-2$

$3.75 \mathrm{E}-3$

Selected range is from $0.00 E+0$ to $\infty$

Mean value in simulation was $1.01 \mathrm{E}-2$

Assumption: $\quad J(C H-D R U M I G N-\#)$

Lognormal distribution with parameters:

Mean

1.00E-3

Standard Dev.

$3.75 E-3$

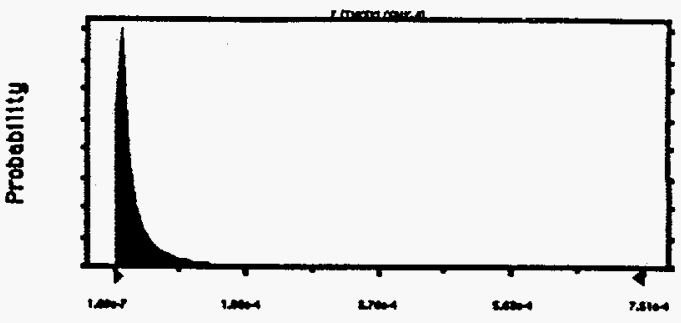

Cell: $\quad B 17$

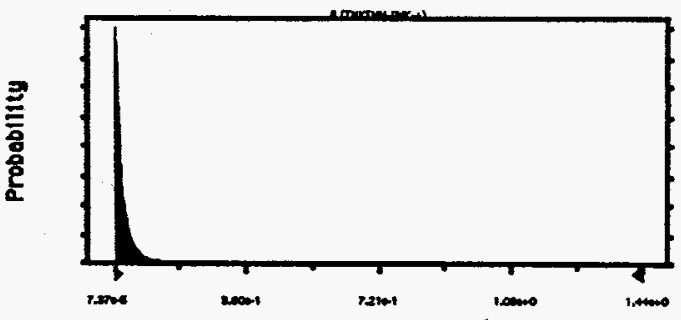

Cell: B18

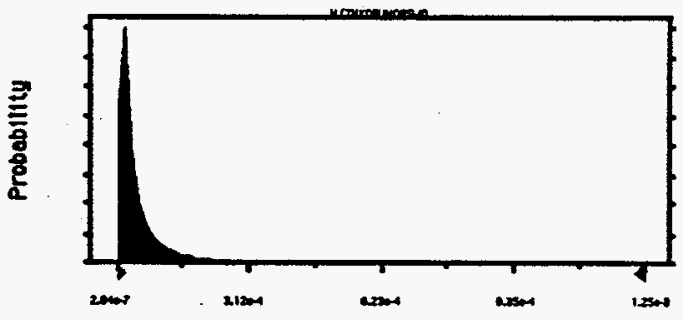

Cell: B19

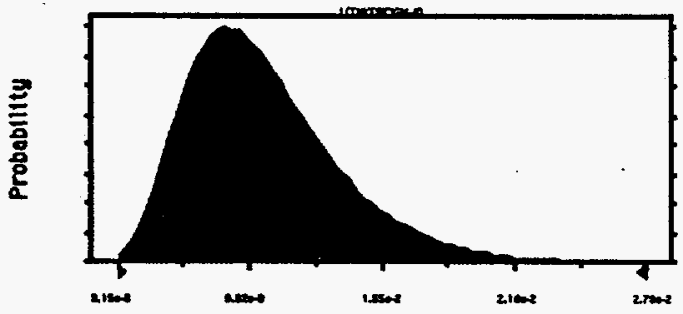

Cell: B20

Selected range is from $0.00 E+0$ to $\infty$ 
Mean value in simulation was $9.91 \mathrm{E}-4$

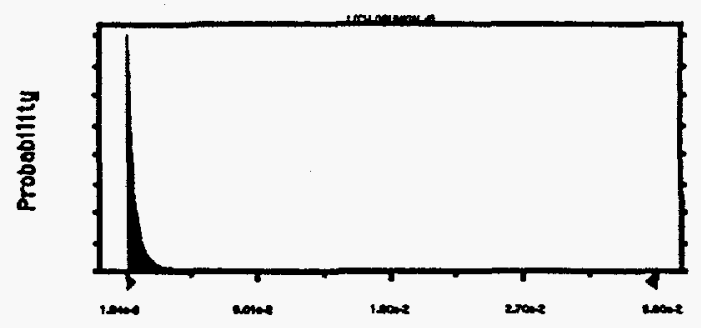

Assumption: $\quad F($ TNKEXC-PNK-+)

Cell: $\quad B 16$

Lognormal distribution with parameters:

Mean

6.00E-1

Standard Dev.

$2.25 \mathrm{E}+0$

Selected range is from $0.00 E+0$ to $\infty$ Mean value in simulation was $5.68 \mathrm{E}-1$

Assumption: $\quad \mathrm{K}$ (INVDRUMCON-\#)

Lognormal distribution with parameters:

Mean

Standard Dev.

5.00E-1

$1.87 \mathrm{E}+0$

Selected range is from $0.00 E+0$ to $1.00 E+0$

Mean value in simulation was $1.90 \mathrm{E}-1$

\section{Assumption: L (TNKFEL-PNK-t)}

Lognormal distribution with parameters:

Mean

1.00E-2

Standard Dev.

$3.75 E-2$

Selected range is from $0.00 E+0$ to $\infty$

Mean value in simulation was $1.09 \mathrm{E}-2$

Assumption: $\quad M($ FLK----|GN-+)

Lognormal distribution with parameters:

Mean

8.00E-4

Standard Dev.

$3.00 \mathrm{E}-3$

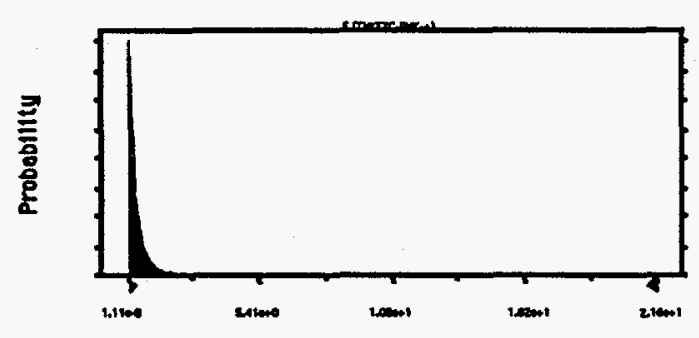

Cell: $\quad$ B21

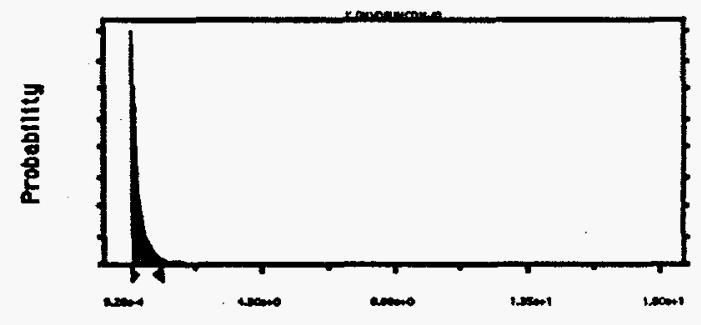

Cell: B22

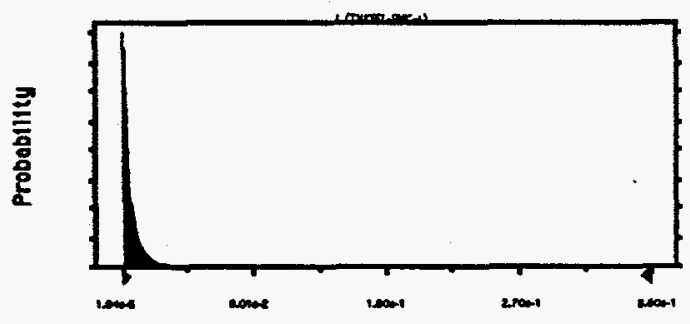

Cell: $\quad$ B23

Selected range is from $0.00 E+0$ to $\infty$ 
Assumption: $\quad M($ FLK----IGN-+) (Cont'd)

Mean value in simulation was $8.22 \mathrm{E}-4$

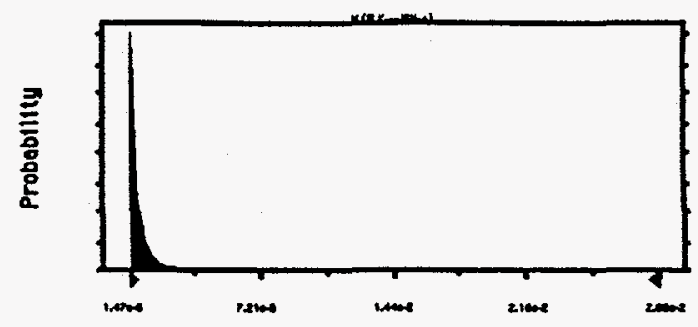

Assumption: $\quad \mathrm{N}$ (TNKHEATPRE-\#)

Cell: $\quad$ B24

Lognormal distribution with parameters:

Mean

$1.00 \mathrm{E}-1$

Standard Dev.

3.75E-1

Selected range is from $0.00 E+0$ to $1.00 E+0$ Mean value in simulation was $7.38 \mathrm{E}-2$

Assumption: $\quad 0($ EXC----IGN-+)

Lognormal distribution with parameters:

Mean

2.00E-5

Standard Dev.

$7.49 \mathrm{E}-5$

Selected range is from $0.00 E+0$ to $\infty$

Mean value in simulation was $1.95 \mathrm{E}-5$

Assumption: $\quad \mathrm{Q}(\mathrm{FEL}---\mathrm{G} \mathrm{GN}-+$ )

Lognormal distribution with parameters:

Mean

2.00E-5

Standard Dev.

7.49E-5

Selected range is from $0.00 E+0$ to $\infty$

Mean value in simulation was $1.85 \mathrm{E}-5$

Assumption: $\quad \mathrm{R}$ (EMMDRUMDRP-+)

Lognormal distribution with parameters:

Mean

$1.00 \mathrm{E}+1$

Standard Dev.

$3.75 E+1$

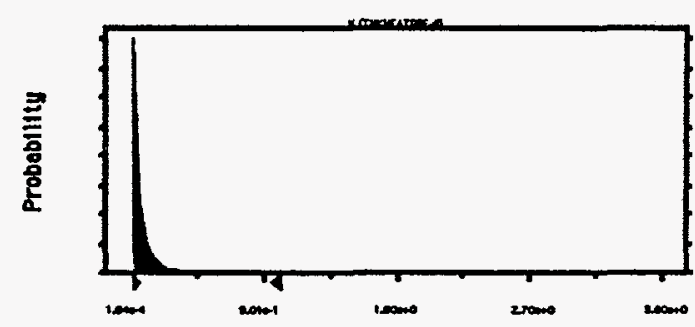

Cell: B25

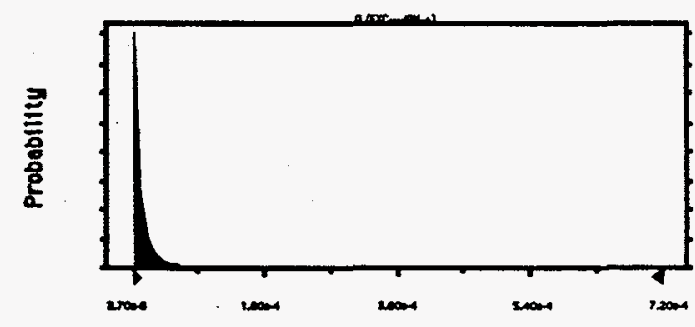

Cell: $\quad$ B26

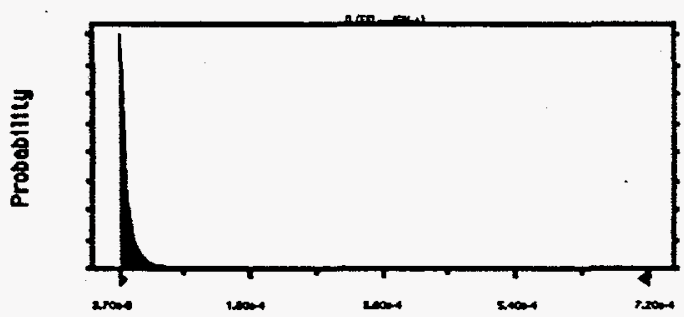

Cell: $\quad$ B27

Selected range is from $0.00 E+0$ to $\infty$ 
WSRC-TR-93-451

Rev. 2

Assumption: $\mathrm{R}$ (EMMDRUMDRP-+) (Cont'd)

Cell: B27

Mean value in simulation was $1.03 E+1$

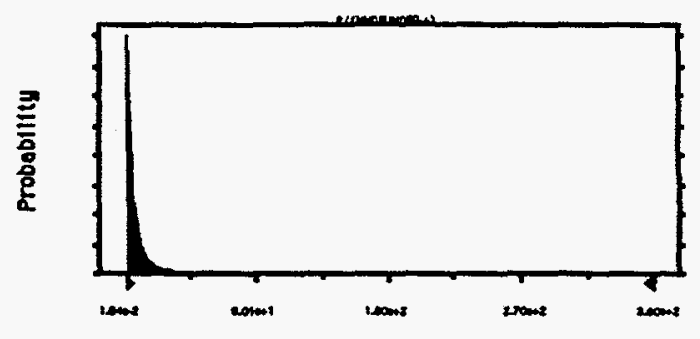

Assumption: T(TRKVACUIGN-+)

Cell: $\quad$ B28

Lognormal distribution with parameters:

$\begin{array}{ll}\text { Mean } & 2.00 E-4 \\ \text { Standard Dev. } & 7.49 E-4\end{array}$

Selected range is from $0.00 E+0$ to $\infty$

Mean value in simulation was $1.88 \mathrm{E}-4$

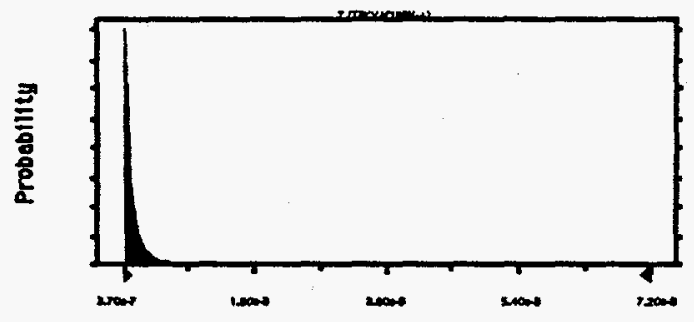

End of Assumptions 
WSRC-TR-93-451

Rev. 2

Appendix C - Calculation of Frequency for Second Drum Deflagration

C-1 


\section{Derivation of Frequency for a Subsequent Deflagration of a Drum Initiated by a Drum Lid Puncture}

A calculation was made to determine if it was credible for the drum lid blown from the deflagrating drum (as described in Section 6.6) to penetrate an adjacent drum and cause a subsequent deflagration. Deflagration tests performed at SRS (on two separate occasions) indicate that when a lid blows off of a drum due to the ignition of the hydrogen mixture in the drum, the lid travels straight up at a speed of $109 \mathrm{ft} / \mathrm{sec}$ for the first 2.5 feet. Using the Ballistic Research Laboratory equation for a missile strike, it cannot be proven that a drum lid, if traveling as a disk (i.e. makes contact with the drum on the rim), would not penetrate a drum. Use of this equation is very conservative, but until more detailed analyses can be performed on the drum response to a lid collision, the potential for a second deflagration must be considered. The following calculation was made to estimate the frequency of a second deflagration due to a lid puncture.

From the process description, it was interpreted that the following sequence would occur when removing drums: drums from the top layer would be removed from the first row; then, drums from the bottom row would be removed; next drums from the top layer of the next row would be removed. Thus the configuration could look like the following:

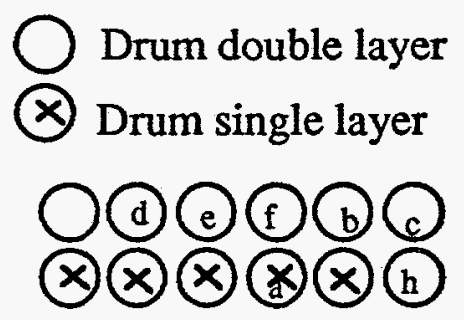

It is only possible for the lids from the bottom drums to hit the top drums, thus the probability of a drum lid hitting another drum is immediately reduced by $50 \%$. Based on the observed data from the drum deflagration tests, it will conservatively be estimated that $90 \%$ of drum lids will travel vertically for the first 3 feet of motion. Therefore, it is estimated that $10 \%$ of drum deflagrations would result in the lid blowing off at an angle small enough so as to travel a mostly horizontal distance with the vertical distance not to exceed 3 feet for the first 5 feet of horizontal travel. In order for the drum lid to penetrate the drum that it would hit, the lid would have to hit the drum as a disk (i.e. the edge of the lid rim would make contact with the drum). If the lid hit the drum with its flat face a puncture is not possible. Since the drums are stacked in a close array any adjacent drum would be hit with the face of the lid. The only potential for a drum to be hit with the lid as a disk, is a top drum on the same row as the deflagrating drum with at least two feet of spacing between it. For example, if drum " $a$ " were being moved and a deflagration occurred, there is a potential for the lid from drum "a" to hit drum " $h$ " as a disk. If the lid from drum "a" hit drums "e", "f", or "b", no puncture would occur because of the surface area of the face of the lid. It is not possible for the lid from drum "a" to hit drums " $d$ " or "c" without hitting "e" or "b", except for low-angle glancing hits (due to as-built stack array imperfections), which are not expected to cause punctures. 
If the lid were to be blown from drum " $a$ ", there are a number of angles at which it could travel. For simplicity, it will be conservatively estimated that the number of possible angles it could travel is 12 (this is a very conservative number considerin $_{i}$ the three dimensional area, although credit has already been taken for the straight vertical direction). The probability that the drum lid blows off at an angle to hit a drum as a disk is $1 / 12$ or $8 \mathrm{E}-2$.

To estimate the frequency that this blown lid causes a deflagration in the drum that it hits, the probability that the drum contains an explosive mixture of hydrogen must be considered. This probability is: $28 \%$ of the drums contain explosive hydrogen mixtures $* 80 \%$ of the drums are hydrogen tight $* 50 \%$ of the punctures ignite the hydrogen mixture (all data is from the fault tree analysis for drum deitagraitons) which equates to 1.1E-1.

Therefore, the frequency calculation for the deflagrations caused by lid penetration from another drum is calculated by :

frequency $=50 \%$ drums on bottom row $* 3.3 \mathrm{E}-1$ deflagrations/year $* 10 \%$ of drum lids blow off at some angle * $8 \mathrm{E}-2$ probability for the angle * $1.1 \mathrm{E}-1$ for hydrogen mixture ignition $\quad=1.45 \mathrm{E}-4$ per year (approximately $1.5 \mathrm{E}-4)$

A third drum deflagration is not considered credible since the drums are stacked two high, and a lid blown from the top tier could not hit another drum on its ascent. 